Article

\title{
Studies towards the Design and Synthesis of Novel 1,5-Diaryl-1H-imidazole-4-carboxylic Acids and 1,5-Diaryl-1H-imidazole-4-carbohydrazides as Host LEDGF/p75 and HIV-1 Integrase Interaction Inhibitors
}

\author{
Thompho J. Rashamuse ${ }^{1,2}$, Muhammad Q. Fish ${ }^{1}$, E. Mabel Coyanis ${ }^{1, *}$ and Moira L. Bode ${ }^{2, *(D)}$ \\ 1 Advanced Materials Division, Mintek, Private Bag X3015, Randburg 2194, South Africa; \\ jasonr@mintek.co.za (T.J.R.); QasimF@mintek.co.za (M.Q.F.) \\ 2 Molecular Sciences Institute, School of Chemistry, University of the Witwatersrand, Private Bag 3, PO Wits, \\ Johannesburg 2050, South Africa \\ * Correspondence: mabelc@mintek.co.za (E.M.C.); Moira.Bode@wits.ac.za (M.L.B.)
}

\section{check for}

updates

Citation: Rashamuse, T.J.; Fish, M.Q.; Coyanis, E.M.; Bode, M.L. Studies towards the Design and Synthesis of Novel 1,5-Diaryl-1H-imidazole-4carboxylic Acids and 1,5-Diaryl-1Himidazole-4-carbohydrazides as Host LEDGF/p75 and HIV-1 Integrase Interaction Inhibitors. Molecules 2021, 26, 6203. https://doi.org/10.3390/ molecules 26206203

Academic Editor: Stanislav Gobec

Received: 14 September 2021

Accepted: 11 October 2021

Published: 14 October 2021

Publisher's Note: MDPI stays neutral with regard to jurisdictional claims in published maps and institutional affiliations.

Copyright: (c) 2021 by the authors. Licensee MDPI, Basel, Switzerland. This article is an open access article distributed under the terms and conditions of the Creative Commons Attribution (CC BY) license (https:/ / creativecommons.org/licenses/by/ $4.0 /)$.
Abstract: Two targeted sets of novel 1,5-diaryl- $1 H$-imidazole-4-carboxylic acids $\mathbf{1 0}$ and carbohydrazides 11 were designed and synthesized from their corresponding ester intermediates 17, which were prepared via cycloaddition of ethyl isocyanoacetate $\mathbf{1 6}$ and diarylimidoyl chlorides 15. Evaluation of these new target scaffolds in the AlphaScreen ${ }^{\mathrm{TM}}$ HIV-1 IN-LEDGF/p75 inhibition assay identified seventeen compounds exceeding the pre-defined $50 \%$ inhibitory threshold at $100 \mu \mathrm{M}$ concentration. Further evaluation of these compounds in the HIV-1 IN strand transfer assay at $100 \mu \mathrm{M}$ showed that none of the compounds (with the exception of 10a, 101, and 11k, with marginal inhibitory percentages) were actively bound to the active site, indicating that they are selectively binding to the LEDGF/p75-binding pocket. In a cell-based HIV-1 antiviral assay, compounds 11a, 11b, 11g, and 11h exhibited moderate antiviral percentage inhibition of 33-45\% with cytotoxicity $\left(\mathrm{CC}_{50}\right)$ values of $>200 \mu \mathrm{M}, 158.4 \mu \mathrm{M},>200 \mu \mathrm{M}$, and $50.4 \mu \mathrm{M}$, respectively. The antiviral inhibitory activity displayed by $\mathbf{1 1 h}$ was attributed to its toxicity. Upon further validation of their ability to induce multimerization in a Western blot gel assay, compounds 11a, 11b, and 11h appeared to increase higher-order forms of IN.

Keywords: ethyl 1,5-diaryl-1H-imidazole-4-carboxylates; 1,5-diaryl-1H-imidazole-4-carboxylic acids; 1,5-diaryl-1 $H$-imidazole-4-carbohydrazides; ethyl isocyanoacetate; $\mathrm{N}$-aryl-benzimidoyl chlorides; HIV-1 integrase; LEDGF/p75

\section{Introduction}

The human immunodeficiency virus type 1 (HIV-1), the causative agent of acquired immune deficiency syndrome (AIDS), is one of the world's greatest health and development challenges. Despite chemotherapeutic interventions for the virus being developed through active research, the emergence of highly drug-resistant strains against the current approved Food and Drug Administration (FDA) antiretroviral drugs takes a significant toll on the global fight against HIV-1 [1-7]. Thus, there has been an ongoing search for new treatment options targeting novel steps in the HIV-1 replication cycle. Targeting the active host protein and HIV-1 protein interactions has become a viable therapeutic approach. A typical example is a lens epithelium-derived growth factor (LEDGF/p75) and HIV-1 integrase (IN) protein-protein interaction [8-10]. IN is one of three multifaceted essential enzymes required for HIV-1 replication. This $32 \mathrm{kDa}$ protein consists of 288 amino acids and is composed of the catalytic core, $N$-terminal and C-terminal functional domains [11-14]. The main protein function is to allow reliable integration of viral DNA genomes into host cells $[11,15]$. There are currently only four IN inhibitors on the market that have been clinically tested and approved by the FDA, including elvitegravir, dolutegravir, raltegravir, 
and bictegravir [16-19]. These inhibitors are referred to as strand transfer inhibitors (INSTIs) and share the identical mechanistic mode of action of blocking the strand transfer step through binding to the active site of viral IN [14-17]. Despite the success of highly active antiretroviral therapy (HAART), a new generation of drugs is needed to overcome multi-drug resistance, enhance adherence, and lower toxicities [1-7].

During the last two decades, there have been significant efforts to develop small molecules as clinical alternatives to INSTIs for treating HIV-1 infected individuals [20-26]. These compounds are often referred to as allosteric integrase inhibitors (ALLINIs) or LEDGF/p75-IN inhibitors (LEDGINs), IN-LEDGF/p75 allosteric inhibitors (INLAIs), noncatalytic site integrase inhibitors (NCINIs), and selective multimeric IN inhibitors (MINIs) [23-26]. They bind to LEDGF/p75 binding sites on IN, leading to aberrant multimerization of HIV-1 IN, which ultimately results in defective virions [16-25]. Examples include BI-1001 (1), BI 224436 (2), MUT 101 (3), MUT-A (4), indole derivatives (5), 5-carbonyl- $1 \mathrm{H}$-imidazole-4-carboxamides (6 and 7), and $\mathrm{N}$-acylhydrazone-based derivatives (8) (Figure 1) [23-29]. Although none of the LEDGF/p75-IN inhibitors reported to date have been approved clinically, they provide proof-of-concept that developing small molecules targeting the LEDGF/p75-IN interaction is an attractive prospect for new antiviral drug discovery.<smiles>COc1c(-c2ccc(Cl)cc2)c2cc(Br)ccc2n1C</smiles><smiles>Cc1nc2ccccc2c(-c2ccc3c4c(ccnc24)CCO3)c1C(OC(C)(C)C)C(=O)O</smiles>

2<smiles>Cn1c([C@H](OC(C)(C)C)C(=O)O)c(-c2ccccc2)c2ccccc21</smiles>

5
$\mathrm{H}_{2} \mathrm{~N}$<smiles>O=C(Nc1ccc(I)cc1)c1nc[nH]c1C(=O)O</smiles><smiles>Cc1nc2c(c(-c3ccc4c(c3)CCCO4)c1[C@H](OC(C)(C)C)C(=O)O)CCCC2</smiles>

3<smiles>NC(=O)c1[nH]cnc1C(=O)Nc1ccccn1</smiles>

7<smiles>Cc1sc(-c2ccncc2)c(C2=CCC(C)(C)CC2)c1[C@@H](OC(C)(C)C)C(=O)O</smiles>

4

Figure 1. Structures of different of LEDGF/p75-IN inhibitors (1-8).

Research efforts by our group directed towards the identification of potential LEDGF/p75IN inhibitors led to the discovery of 1,5-diaryl- $1 \mathrm{H}$-imidazole 9 as a hit compound (Figure 2) [30]. While the candidate hit compound 9 could not achieve antiviral effects in vitro, it contained the common $N$-heterocycle core $(\mathbf{A})$ and two aromatic rings $(\mathbf{B}$ and $\mathbf{C})$ present in inhibitors of the HIV-1 IN-LEDGF/p75 interaction.<smiles>NNC(=O)c1ncn(-c2ccc(Br)cc2)c1-c1ccc(F)cc1</smiles>

Figure 2. Modification of hit compound 9 by including a carboxylic acid (10a) or carbohydrazide group (11a). 
Evaluation of LEDGF/p75-IN interaction inhibitors 1-6 has shown that the carboxylic acid $(-\mathrm{COOH})$ functionality present in these structures contributes significantly to their binding properties [23-28]. Additionally, compounds 7 and 8, containing a carbohydrazide moiety, have been shown to inhibit the LEDGF/p75-IN interaction $[28,29,31]$. Based on this information, we postulated that addition of a carboxylic acid functionality or a carbohydrazide motif to the hit compound 9, to give 10a and 11a, respectively, could significantly improve the properties of the parent scaffold (Figure 2).

The 1,5-disubstituted imidazole-4-carboxylate esters are ubiquitous structural motifs in many compounds displaying biological properties $[32,33]$. One of the efficient methods for making such 1,5-disubstituted imidazole-4-carboxylates would be their direct formation from commercially available $\alpha$-isocyanoacetates. These $\alpha$-isocyanoacetates are useful multipurpose reagents for the construction of various nitrogen-containing heterocycles [34,35]. Different five-membered nitrogen-containing heterocycles like thiazole [36,37], imidazole [31-33,38-43], indole [44-46], oxazole [47], pyrrole [48,49], and triazole [50,51] have been built using these synthons. Isocyanoacetate building blocks have attracted the interest of researchers owing to their structural characteristics, reactivity, and reliability. Their structures encompass four densely packed reaction sites, namely the isocyanide motif, $\alpha$-acidic methine centre, a substituted R-group (which allows for considerable variability), and the carboxylate ester group [40,41]. These reactive sites permit a diverse range of organic transformations, affording $\alpha$-adducts.

A survey of the literature reveals that a few synthetic methods for constructing 1,5disubstituted-imidazole-4-carboxylates using $\alpha$-isocyanoacetate synthons have been reported. One of the first syntheses was described in 1978 by Hunt and co-workers [38], where the condensation of the potassium salt of ethyl isocyanoacetate with isothioureas in hexamethylphosphoric triamide (HMPT) at room temperature catalyzed by copper (I) chloride $(\mathrm{CuCl})$ afforded a mixture of disubstituted imidazole-4-carboxylate esters in various yields as presented in Scheme 1a. Another approach was reported in 1994 by Nunami and co-workers [39] in which key intermediate 3-bromo-2-isocyanoacrylates (BICA) were easily derived from isocyanoacetate esters, followed by reaction with a variety of primary amines in the presence of triethylamine $\left(\mathrm{Et}_{3} \mathrm{~N}\right)$ in $\mathrm{N}, \mathrm{N}$-dimethylformamide (DMF) as solvent (Scheme 1b). Furthermore, in 2011, Meng and co-workers [33] demonstrated a strategy to introduce a range of 1,5-disubstituted- $1 \mathrm{H}$-imidazole-4-carboxylate ester derivatives as intermediates towards the synthesis of chromeno $[3,4-d]$ imidazol-4-one by using readily available ethyl isocyanoacetate, primary aliphatic amines, and an aldehyde in the presence of copper iodide (CuI) and pyridine in methanol (MeOH) heated at $50^{\circ} \mathrm{C}$ (Scheme 1c). Aguilar and co-workers [40] reported a one-pot two-step strategy for the preparation of a disubstituted imidazole-4-carboxylate ester. This procedure involves first coupling 4-chloroaniline with 4-iodobenzoyl chloride using 1-ethyl-(3-dimethylaminopropyl)carbodiimide (EDCI) to produce the amide. The amide is then treated with chlorophosphate to generate unstable iminophosphates in situ, followed by condensation under basic conditions with ethyl isocyanoacetate to produce the desired compound (Scheme 1d). This procedure only reported one example and the approach required strictly anhydrous conditions. Additionally, Cai and co-workers [41] in 2019 reported an annulation between $\alpha$-isocyanoacetates and ketenimines in the presence of a base, potassium tert-butoxide ( $t$-BuOK), in DMF at $40{ }^{\circ} \mathrm{C}$ as an efficient and straightforward synthesis of disubstituted imidazole-4-carboxylate ester derivatives in good yields (Scheme 1e). Additionally, Hu and co-workers [42] in 2020 reported a new method for preparing 1,5-disubstituted imidazole-4-carboxylate esters by $t$-BuOK-mediated annulation of ester isocyanoacetates with trifluoroacetimidoyl chlorides (Scheme 1f). The methodology includes mild reaction conditions and uses readily available reagents. However, only two examples were reported utilizing ester isocyanoacetate synthons in this approach. More recently, Lv and co-workers [43] in 2021 described the construction of these compounds in good yields by reacting $\alpha$-isocyanoacetates with nitrones catalyzed by silver trifluoromethanesulfonate (AgOTf) in the presence of potassium trifluo- 
romethanesulfonate (KOTf) in toluene (PhMe) as a solvent under a nitrogen atmosphere (Scheme 1g).

(a) Hunt et al., (1978)

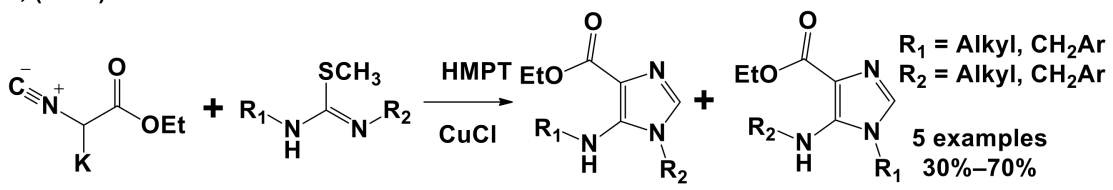

(b) Nunami et al., (1994)

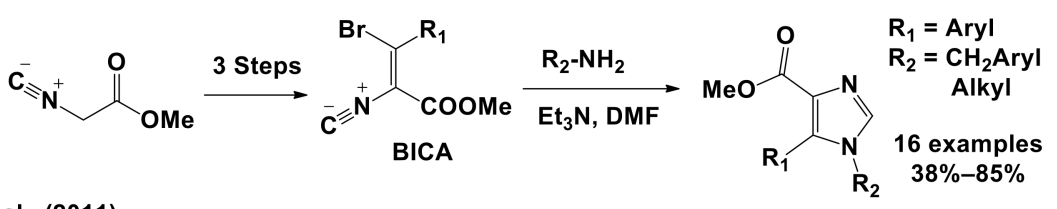

(c) Meng et al., (2011)

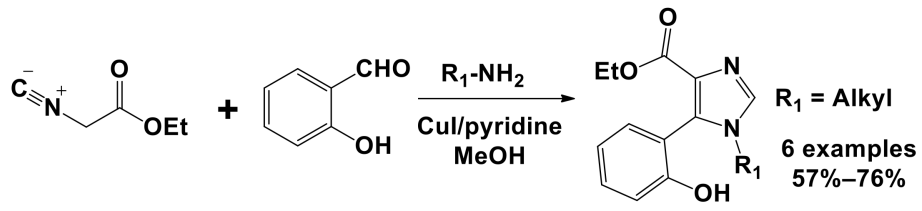

(d) Aguilar et al., (2013)

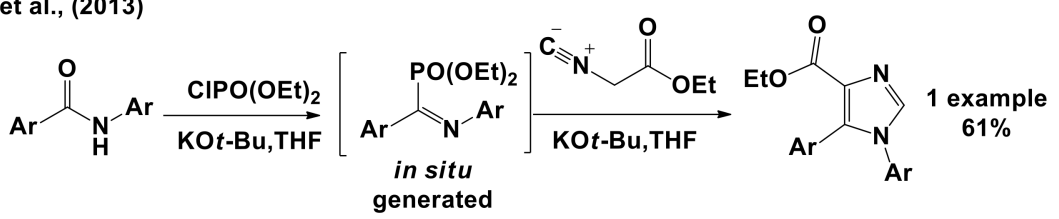

(e) Cai et al., (2019)

$$
\text { (2019) }
$$

(f) Hu et al., (2020)

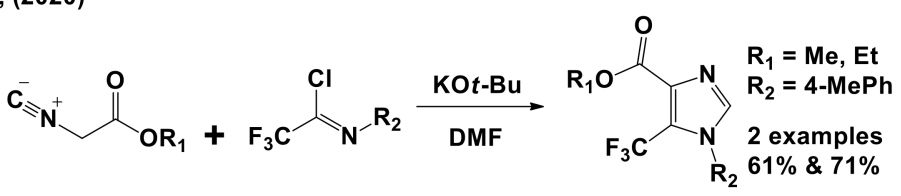

(g) Lv et al., (2021)

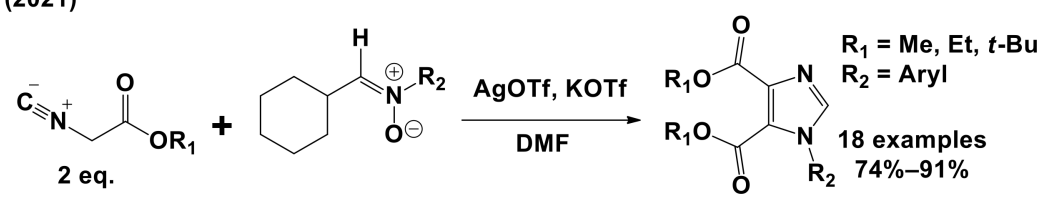

(h) This work

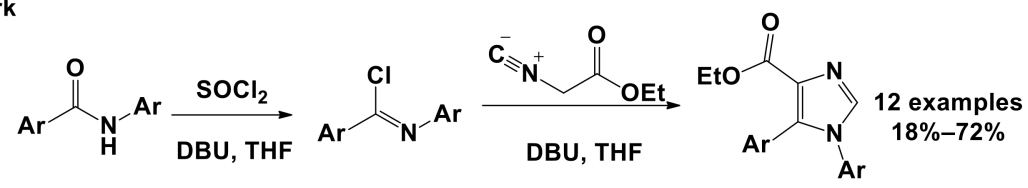

Scheme 1. Synthesis of 1,5-disubstituted-imidazole-4-carboxylate esters using $\alpha$-isocyanoacetates.

As part of our ongoing interest in the design of possible inhibitors of the HIV-1 IN and LEDGF/p75 protein-protein interaction [30], we directed our attention to the synthesis of 1,5-disubstitued- $1 \mathrm{H}$-imidazole-4-carboxylate esters. Herein we describe a novel and efficient approach for the synthesis of diaryl-imidazole-4-carboxylate esters via cycloaddition of an $\alpha$-isocyanoacetate with stable $N$-aryl-benzimidoyl chloride in- 
termediates (Scheme $1 \mathrm{~h}$ ). None of the previously reported synthetic methods to these compounds [33,40-43] make use of diarylimidoyl chlorides and isocyanoacetate esters. The carboxylate esters prepared using this new methodology were subsequently converted into the corresponding 1,5-diaryl- $1 H$-imidazole-4-carboxylic acids and 1,5-diaryl- $1 \mathrm{H}$-imidazole4-carbohydrazides, which were then evaluated for their ability to bind to the novel HIV-1 IN dimer interface pocket.

\section{Results and Discussion}

\subsection{Testing the Hypothesis In Silico}

In order to test our hypothesis and provide some proof of concept for preparation of the proposed analogues (Figure 2), target candidates 10a and 11a were docked into the LEDGF/p75-binding pocket of HIV-1 integrase to gain a deeper understanding of the possible binding interactions. The X-ray crystal structure of HIV-1 IN dimer (PDB code: 4NYF) in complex with the small molecule, BI 224436 (2), was used for a better understanding of binding interactions of the tested ligands [27]. The model developed suggested a clear difference in the positioning of the two ligands within the binding site. The carboxylic acid moiety of compound 10a was shown to form hydrogen bonds with critical histidine (His) 171, glutamic acid (Glu) 170, and threonine (Thr) 174 amino acid residues of HIV-1 IN, while the imidazole motif is predicted to exhibit hydrogen bonding with the glutamic acid 170 residue as presented in Figure 3a,b. Moreover, the 4-fluorophenyl moiety is shown to be positioned towards hydrophobic alanine (Ala) 128 and alanine 129 residues while the 4-bromophenyl moiety is positioned towards the hydrophobic pockets occupied by threonine 125. On the other hand, the carbohydrazide motif of 11a is predicted to interact with threonine 125 and glycine (Gln) 95 amino acid residues. In addition, the 4-fluorophenyl moiety is projected towards the Glycine 168 residue while the 4-bromophenyl moiety projects towards histidine 171 and glutamic acid 170 as shown in Figure $3 c, d$. The modelling data suggest that these scaffolds interact with critical amino acid residues in the LEDGF/p75 binding site of HIV-1 integrase.

\subsection{Chemistry}

\subsubsection{Synthesis of Key 1,5-Diaryl-1H-imidazole-4-carboxylate Esters}

Possible synthetic pathways were considered for the synthesis of the desired target 1,5diaryl- $1 H$-imidazole-4-carboxylic acids 10 and 1,5-diaryl- $1 H$-imidazole-4-carbohydrazides 11. The approach adopted was to start with reaction of an acyl chloride $\mathbf{1 2}$ with an aniline derivative 13 to give the corresponding amide 14 that could be readily converted into the corresponding imidoyl chloride 15 (Scheme 2). The key step in the synthesis was the cycloaddition reaction between ethyl isocyanoacetate $\mathbf{1 6}$ and a range of imidoyl chlorides to construct a range of key 1,5-diaryl- $1 \mathrm{H}$-imidazole-4-carboxylate ester intermediates $\mathbf{1 7}$. Facile conversion of the ester intermediates into their corresponding carboxylic acid and carbohydrazide derivatives ultimately gave rise to the desired targets $\mathbf{1 0}$ and $\mathbf{1 1}$, respectively. Judicial choice of differently substituted starting materials using this approach enabled a detailed and thorough structure-activity relationship (SAR) analysis of the desired final compounds to be undertaken. The route was initially tested starting from commercially available 4fluorobenzoyl chloride 12a and 4-bromoaniline 13a. A mixture of 4-fluorobenzoyl chloride 12a and 4-bromoaniline 13a in ethyl acetate in the presence of $\mathrm{Et}_{3} \mathrm{~N}$ was reacted at room temperature for $16 \mathrm{~h}$ to afford $\mathrm{N}$-(4-bromophenyl)-4-fluorobenzamide 14a in excellent yield, which was utilized directly in the next step without purification [51-53]. The amide 14a was then subjected to a neat reaction by heating under reflux with excess $\mathrm{SOCl}_{2}$ for $8 \mathrm{~h}$ to give $\mathrm{N}$-(4-bromophenyl)-4-fluorobenzimidoyl chloride 15a. This imidoyl chloride was isolated in quantitative yield and was subsequently used without purification [51,54-56]. Compound 15a was then subjected to reaction with ethyl isocyanoacetate 16. Specifically, a mixture of stoichiometric amounts of ethyl isocyanoacetate 16, 1,8-diazabicyclo[5.4.0]undec-7-ene (DBU) in dry THF under argon was cooled to $-78{ }^{\circ} \mathrm{C}$, followed by subsequent addition of $15 a$. The reaction was allowed to warm to room temperature and stirred for $48 \mathrm{~h}$, affording the desired 
novel ethyl 1-(4-bromophenyl)-5-(4-fluorophenyl)- $1 H$-imidazole-4-carboxylate 17a in 64\% yield, after column chromatographic purification.

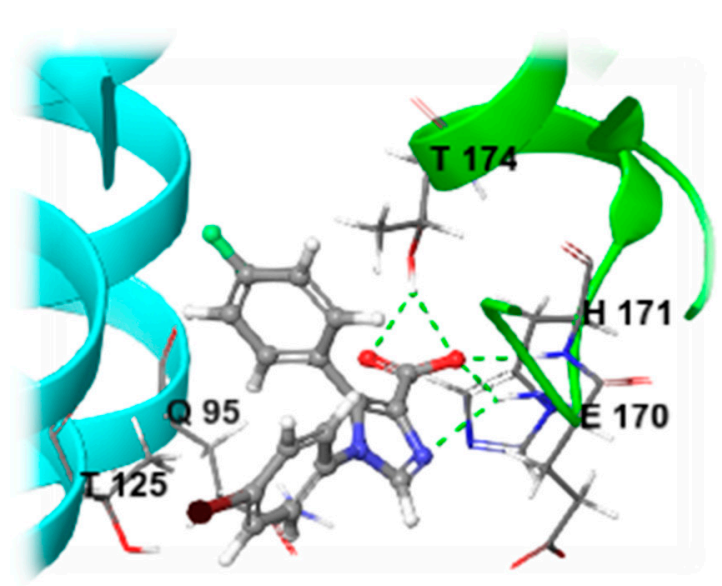

(a)

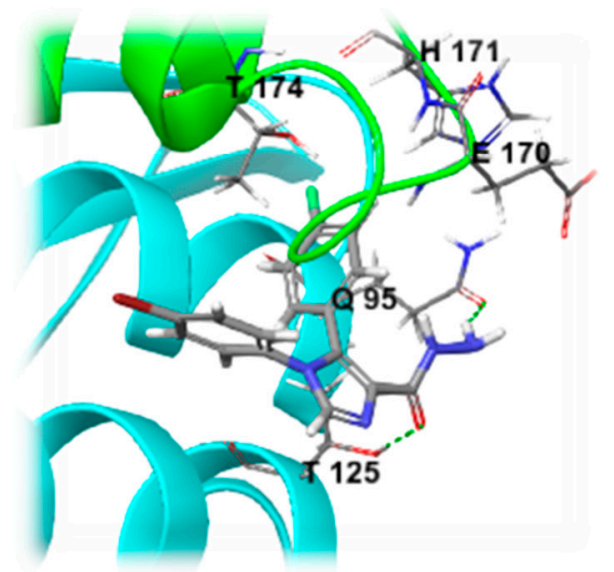

(c)

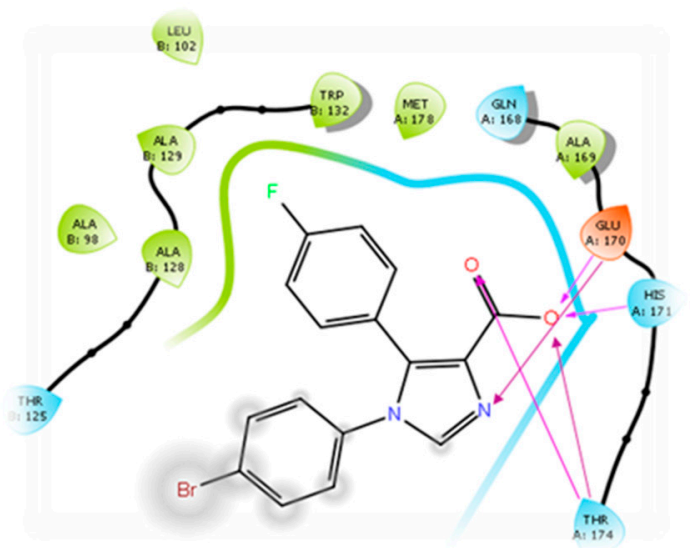

(b)

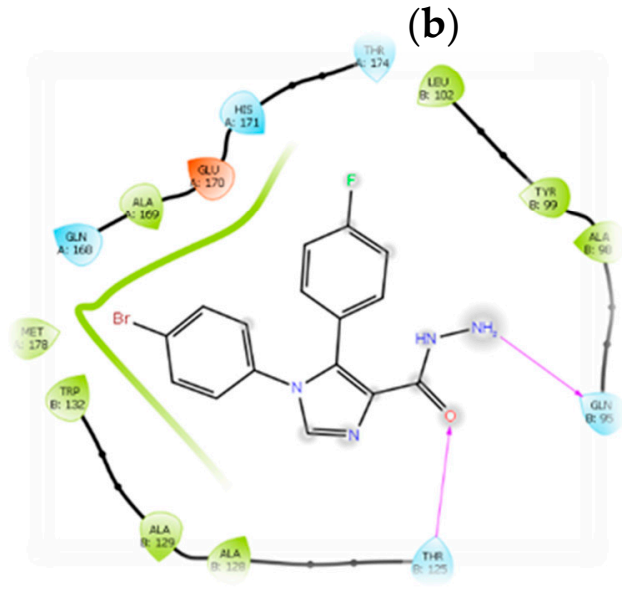

(d)

Figure 3. Docking studies: (a) 3D model of structure 10a docked at the LEDGF/p75 binding site in HIV-1 integrase (PDB code: 4NYF, chain A: green and chain B: light blue); (b) 2D view of structure 10a at the LEDGF/p75 binding site in HIV-1 integrase; (c) the 3D mode of compound 11a binding at the LEDGF/p75 binding site in HIV-1 integrase; (d) 2D image of structure 11a at the LEDGF/p75 binding site in HIV-1 integrase. Hydrogen bonds are represented by the green dotted lines in $3 \mathrm{D}$ structures $(\mathbf{a}, \mathbf{c})$ and as purple arrows in $2 \mathrm{D}$ views $(\mathbf{b}, \mathbf{d})$.

The optimized conditions were then applied to various commercially available benzoyl chlorides $\mathbf{1 2} \mathbf{b}-\mathbf{f}$ and aniline derivatives $\mathbf{1 3} \mathbf{a}-\mathbf{h}$ to establish the scope and limitations of the reaction. First, we studied the transformation of the amides $14 \mathbf{b}-\mathbf{p}$ into the essential $\mathrm{N}$-aryl benzimidoyl chloride intermediates $\mathbf{1 5}$. It was found that intermediates $\mathbf{1 5} \mathbf{b}-\mathbf{n}$ were successfully synthesized in quantitative yields after removal of excess $\mathrm{SOCl}_{2}$ and compounds were used in the subsequent reaction without purification. However, when the aniline ring had two chlorine substituents (at the para- and ortho-positions, i.e., 14o and 14p), no product was obtained and TLC analysis indicated the presence of unreacted starting materials. The series of $N$-aryl benzimidoyl chloride intermediates $\mathbf{1 5 b}-\mathbf{n}$ was then subsequently subjected to cyclization with the isocyanide 16. After column chromatographic purification, only the ethyl 1,5-diaryl- $1 \mathrm{H}$-imidazole-4-carboxylate derivatives derived from aniline motifs substituted with the para-electron-withdrawing groups (i.e., 17a-1 in Table 1) were isolated in adequate purity. It was noted that scaffolds containing electron-donating substituents on the aryl ring directly attached to the 5-position of the imidazole motif 
were obtained in far poorer yield than those containing electron-withdrawing groups. For instance, the reasonable yields of $64 \%$ for $17 \mathrm{a}, 58 \%$ for $17 \mathrm{~b}, 72 \%$ for $17 \mathrm{~g}$, and $67 \%$ for $17 \mathrm{~h}$ were achieved when the electron-withdrawing fluorine atom occupied the para- or the metapositions on the 5-aryl ring. On the other hand, the presence of an electron-donating group (i.e., methyl and methoxy substituents) attached to the para- or the meta-positions of the 5 -aryl group led to poor reactivity and gave $\mathbf{1 7} \mathbf{c}-\mathbf{e}$ and $\mathbf{1 7} \mathbf{i}-\mathbf{k}$ in poor yields of between $18 \%$ and $41 \%$. It was further observed that the absence of substituents on the 5-aryl ring also negatively affected the yields of the products (17e was obtained in $22 \%$ and $\mathbf{1 7 1}$ in $37 \%$ yield). Unfortunately, the presence of electron-donating methyl groups at the para- and ortho- positions on the aryl ring derived from the aniline motif (i.e., substrates 15m and 15n in Scheme 2) was shown to hinder product formation entirely. It is not clear if the difficulty in forming the imidazole ring under the reaction conditions described can be attributed primarily to the steric hindrance of these groups or their electron-donating nature. However, electron-donating groups are expected to strongly disfavor the reaction by decreasing the electrophilicity of the imidoyl chloride carbon atom that undergoes nucleophilic attack by the $\alpha$-carbon of the isocyanide. The structures of compounds $17 \mathbf{a}-\mathbf{1}$ are in accordance with their ${ }^{1} \mathrm{H}$ and ${ }^{13} \mathrm{C}$ NMR spectra (see Supplementary Materials, Figures S1-S24) and MS-ESI. The ${ }^{1} \mathrm{H}$ NMR spectra of compounds $17 \mathbf{a}-1$ are characterized by the presence of the methine proton of the imidazole ring at ca. $7.6 \mathrm{ppm}$, the methylene protons of the ethyl group at ca. $4.2 \mathrm{ppm}$, as well as the methyl protons which appear at ca. $1.2 \mathrm{ppm}$ as a triplet (Figures S1-S24). The ${ }^{13} \mathrm{C}$ NMR spectra of the title compounds displayed the methine-, methylene-, and methyl carbons at ca. 137, 60, and 14 ppm, respectively. To the best of our knowledge, there are no previous reports on the cycloaddition reactions of ethyl isocyanoacetate and $\mathrm{N}$-aryl benzimidoyl chloride intermediates for the preparation of these novel ethyl 1,5-diaryl- $1 H$-imidazole-4-carboxylate derivatives $\mathbf{1 7 a - 1}$ as described herein.

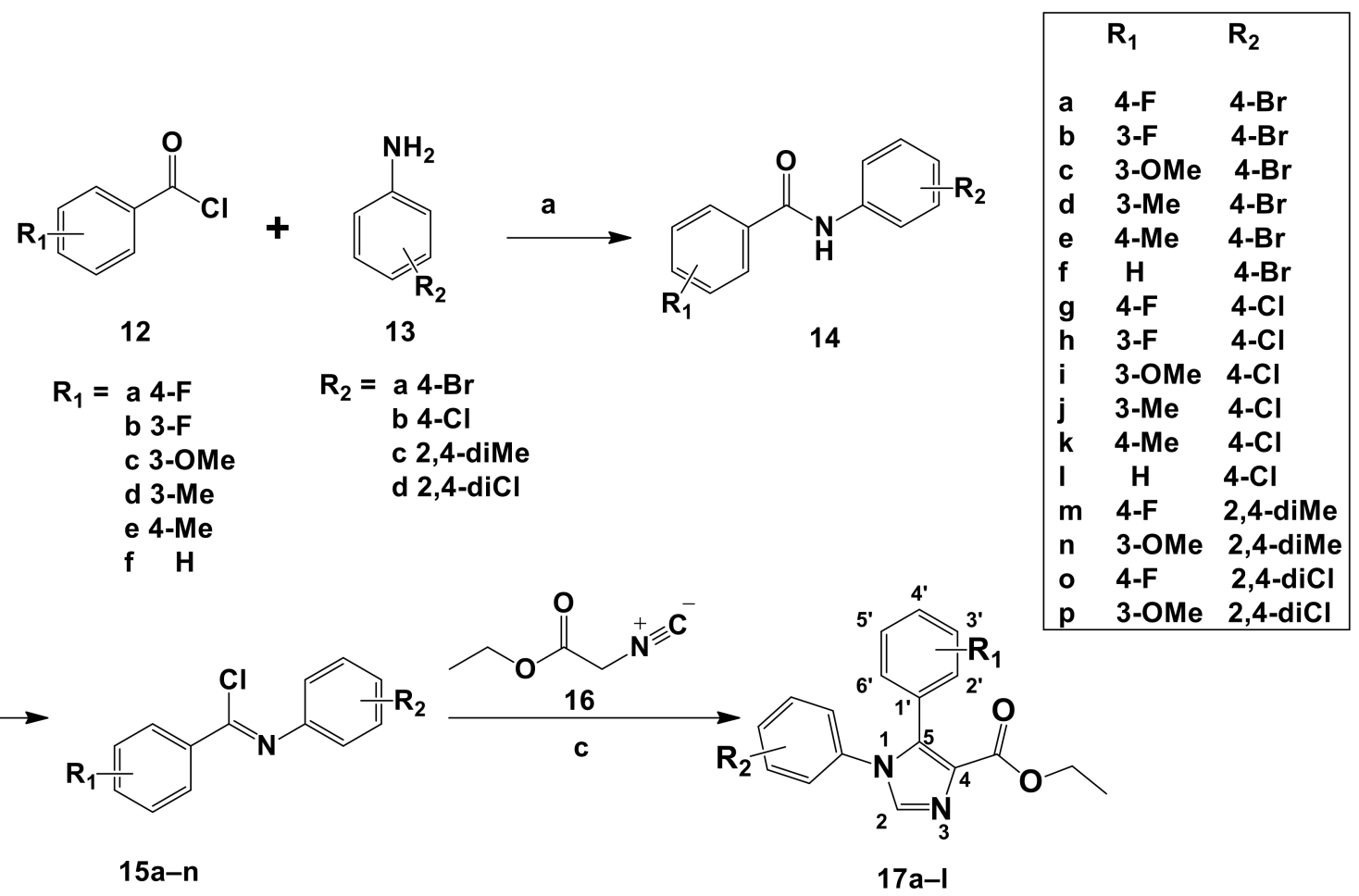

Scheme 2. Synthesis of compounds 14-17. Reaction conditions: (a) $\mathrm{Et}_{3} \mathrm{~N}$, AcOEt, RT, 24 h; (b) SOCl 2 , reflux, 16 h; (c) ethyl isocyanoacetate, $\mathrm{DBU}$, anhydrous $\mathrm{THF},-78^{\circ} \mathrm{C}-\mathrm{RT}, 48 \mathrm{~h}$. 
Table 1. Isolated yields of ethyl 1,5-diaryl- $1 H$-imidazole-4-carboxylates 17a-1.

\begin{tabular}{|c|c|c|c|}
\hline Compound & $\mathbf{R}_{1}$ & $\mathbf{R}_{2}$ & Yield $\%^{1}$ \\
\hline $17 \mathbf{a}$ & $4-\mathrm{F}$ & $4-\mathrm{Br}$ & 64 \\
\hline $17 \mathrm{~b}$ & $3-F$ & $4-\mathrm{Br}$ & 58 \\
\hline $17 \mathrm{c}$ & 3-OMe & $4-\mathrm{Br}$ & 18 \\
\hline $17 d$ & 3-Me & $4-\mathrm{Br}$ & 30 \\
\hline $17 e$ & $4-\mathrm{Me}$ & $4-\mathrm{Br}$ & 35 \\
\hline $17 f$ & $\mathrm{H}$ & $4-\mathrm{Br}$ & 22 \\
\hline $17 \mathrm{~g}$ & $4-\mathrm{F}$ & $4-\mathrm{Cl}$ & 72 \\
\hline $17 \mathrm{~h}$ & $3-\mathrm{F}$ & $4-\mathrm{Cl}$ & 67 \\
\hline $17 \mathbf{i}$ & 3-OMe & $4-\mathrm{Cl}$ & 32 \\
\hline $17 \mathbf{j}$ & 3-Me & $4-\mathrm{Cl}$ & 41 \\
\hline $17 k$ & $4-\mathrm{Me}$ & $4-\mathrm{Cl}$ & 38 \\
\hline 171 & $\mathrm{H}$ & $4-\mathrm{Cl}$ & 42 \\
\hline
\end{tabular}

${ }^{1}$ Yields were determined after column chromatographic purification.

A mechanistic pathway for the formation of 1,5-diaryl- $1 H$-imidazole-4-carboxylate esters $\mathbf{1 7}$ is proposed in Scheme 3. The initial step is thought to involve activation of ethyl isocyanoacetate $\mathbf{1 6}$ under basic conditions to generate anion I [42]. The $\alpha$-carbon of the intermediate I then undertakes a nucleophilic attack on the $\mathrm{C}=\mathrm{N}$ double bond of $\mathbf{1 5}$ to afford intermediate II, with the elimination of a chloride ion as the DBU hydrochloride salt. Intermediate II tautomerizes to produce III, which then undergoes in situ cyclization and proton transfer to give the desired product 17.
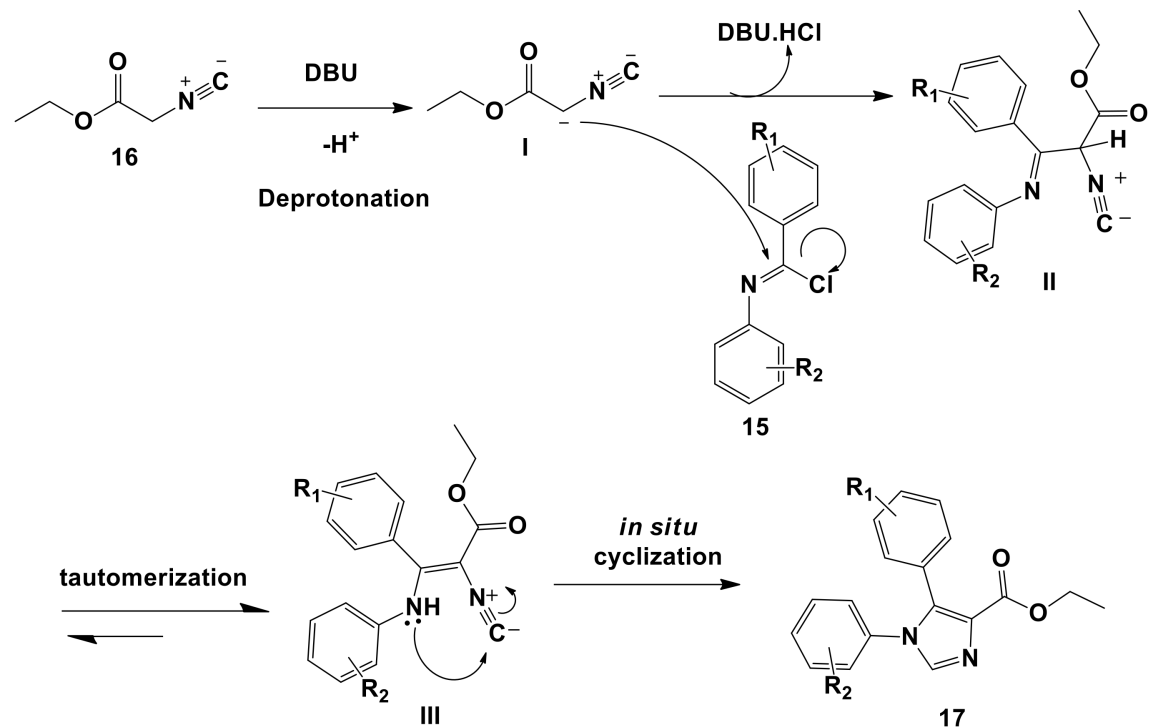

Scheme 3. Plausible mechanism for the formation of product 17.

2.2.2. Synthesis of Novel 5-Diaryl- $1 H$-imidazole-4-carboxylic Acids and 1,5-Diaryl-1H-imidazole-4-carbohydrazides

When compounds $\mathbf{1 7} \mathbf{a}-\mathbf{j}$ were hydrolyzed (using conditions $d$ in Scheme 4), the resulting novel 1,5-diaryl- $1 \mathrm{H}$-imidazole-4-carboxylic acids $\mathbf{1 0 a}-\mathbf{1}$ were obtained in yields ranging from 68 to $83 \%$ (Table 2) while the reaction of $\mathbf{1 7 a}, \mathbf{b}, \mathbf{1 7 d}, \mathbf{e}$, and $\mathbf{1 7} \mathbf{g}-\mathbf{1}$ with hydrazine monohydrate in ethanol heated at reflux temperature (conditions e in Scheme 4) yielded the desired novel 1,5-diaryl- $1 H$-imidazole-4-carbohydrazide derivatives $\mathbf{1 1 a}, \mathbf{b}, \mathbf{1 1 d}, \mathbf{e}, \mathbf{1 1} \mathbf{g}-\mathbf{1}$ 
in yields ranging from 58 to $76 \%$ (Scheme 4) [57]. Unfortunately, there was insufficient material available for the conversion of compounds 11c and 11f to the corresponding hydrazide derivatives. The complete hydrolysis to products $10 \mathrm{a}-1$ was evidenced by the disappearance of the signals corresponding to the ethyl group in their ${ }^{1} \mathrm{H}$ and ${ }^{13} \mathrm{C} N M R$ spectra (Figures S25-S48) and the appearance of a broad, downfield signal at ca. $12 \mathrm{ppm}$ corresponding to the acidic proton of the carboxylic acid group $(\mathrm{COOH})$ in the ${ }^{1} \mathrm{H} N M R$ spectra. Meanwhile, the formation of carbohydrazides $\mathbf{1 1}$ was evident from the appearance of signals between ca. 9.2-9.3 and 4.3-4.4 ppm corresponding to $\mathrm{NH}$ and $\mathrm{NH}_{2}$, respectively (Figures S49-S68).<smiles>[R]c1cccc(-c2c(C(=O)NN)ncn2-c2ccccc2)c1</smiles>

$11 \mathrm{a}-\mathrm{b}, 11 \mathrm{~d}-\mathrm{e}, 11 \mathrm{~g}-\mathrm{I}$<smiles>[R2]c1cccc(-n2cnc(C(=O)OCC)c2-c2ccccc2)c1</smiles>

$17 a-1$<smiles>[R]c1cccc(-c2c(C(=O)O)ncn2-c2ccccc2)c1</smiles>

$10 a-1$

Scheme 4. Synthesis of compounds 10 and 11. Reagents and conditions: (d) i: $\mathrm{NaOH}, \mathrm{H}_{2} \mathrm{O}, \mathrm{MeOH}$ [40], ii: $\mathrm{HCl}, \mathrm{H}_{2} \mathrm{O}$; (e) $\mathrm{NH}_{2} \mathrm{NH}_{2} \cdot \mathrm{H}_{2} \mathrm{O}, \mathrm{EtOH}$, reflux, $24 \mathrm{~h}$ [57].

Table 2. Isolated yields of 1,5-diaryl-1H-imidazole-4-carboxylic acids 10 and 1,5-diaryl- $1 H$-imidazole4-carbohydrazides 11.

\begin{tabular}{|c|c|c|c|c|}
\hline Compound & $\mathbf{R}_{\mathbf{1}}$ & $\mathbf{R}_{\mathbf{2}}$ & $\mathbf{R}_{3}$ & Yield \% \\
\hline $10 a$ & $4-\mathrm{F}$ & $4-\mathrm{Br}$ & $\mathrm{OH}$ & 69 \\
\hline $10 \mathrm{~b}$ & $3-\mathrm{F}$ & $4-\mathrm{Br}$ & $\mathrm{OH}$ & 72 \\
\hline 10c & 3-OMe & $4-\mathrm{Br}$ & $\mathrm{OH}$ & 78 \\
\hline $10 d$ & 3-Me & $4-\mathrm{Br}$ & $\mathrm{OH}$ & 75 \\
\hline $10 \mathrm{e}$ & 4-Me & $4-\mathrm{Br}$ & $\mathrm{OH}$ & 70 \\
\hline $10 f$ & $\mathrm{H}$ & $4-\mathrm{Br}$ & $\mathrm{OH}$ & 63 \\
\hline $10 \mathrm{~g}$ & $4-\mathrm{F}$ & $4-\mathrm{Cl}$ & $\mathrm{OH}$ & 69 \\
\hline $10 \mathrm{~h}$ & $3-\mathrm{F}$ & $4-\mathrm{Cl}$ & $\mathrm{OH}$ & 70 \\
\hline $10 \mathrm{i}$ & 3-OMe & $4-\mathrm{Cl}$ & $\mathrm{OH}$ & 80 \\
\hline $10 \mathrm{j}$ & 3-Me & $4-\mathrm{Cl}$ & $\mathrm{OH}$ & 83 \\
\hline $10 \mathrm{k}$ & 4-Me & $4-\mathrm{Cl}$ & $\mathrm{OH}$ & 79 \\
\hline 101 & $\mathrm{H}$ & $4-\mathrm{Cl}$ & $\mathrm{OH}$ & 77 \\
\hline $11 a$ & $4-\mathrm{F}$ & $4-\mathrm{Br}$ & $\mathrm{NHNH}_{2}$ & 76 \\
\hline $11 b$ & $3-\mathrm{F}$ & $4-\mathrm{Br}$ & $\mathrm{NHNH}_{2}$ & 73 \\
\hline 11d & 3-Me & $4-\mathrm{Br}$ & $\mathrm{NHNH}_{2}$ & 64 \\
\hline 11e & 4-Me & $4-\mathrm{Br}$ & $\mathrm{NHNH}_{2}$ & 68 \\
\hline $11 \mathrm{~g}$ & $4-\mathrm{F}$ & $4-\mathrm{Cl}$ & $\mathrm{NHNH}_{2}$ & 66 \\
\hline $11 \mathrm{~h}$ & $3-F$ & $4-\mathrm{Cl}$ & $\mathrm{NHNH}_{2}$ & 73 \\
\hline $11 \mathrm{i}$ & 3-OMe & $4-\mathrm{Cl}$ & $\mathrm{NHNH}_{2}$ & 68 \\
\hline $11 j$ & 3-Me & $4-\mathrm{Cl}$ & $\mathrm{NHNH}_{2}$ & 62 \\
\hline $11 k$ & 4-Me & $4-\mathrm{Cl}$ & $\mathrm{NHNH}_{2}$ & 63 \\
\hline 111 & $\mathrm{H}$ & $4-\mathrm{Cl}$ & $\mathrm{NHNH}_{2}$ & 58 \\
\hline
\end{tabular}




\subsection{Biological Evaluation}

\subsubsection{HIV-1 IN-LEDGF AlphaScreen ${ }^{\mathrm{TM}}$ Assays}

The inhibition of LEDGF/p75-HIV IN protein-protein activity by the newly synthesized 1,5-diaryl- $1 \mathrm{H}$-imidazole-4-carboxylic acids $\mathbf{1 0 a}-\mathbf{1}$ and 1,5-diaryl-1 $\mathrm{H}$-imidazole4-carbohydrazide derivatives 11a, $\mathbf{b}, \mathbf{1 1} \mathbf{d}, \mathbf{e}$, and $\mathbf{1 1} \mathbf{g}-\mathbf{1}$ was assessed using an Amplified Luminescent Proximity Homogeneous Assay (AlphaScreen ${ }^{\mathrm{TM}}$ assay) at $100 \mu \mathrm{M}$ compound concentration [58]. MUT 101 (3), a compound that inhibits both IN-LEDGF/p75 interaction and IN strand transfer activity while enhancing IN-IN interaction, was used as a positive control [21]. Experimental protocols were conducted in triplicate, and the percentage inhibition results are shown in Table 3. Compounds showing percentage inhibition rates of higher than $50 \%$ were considered to be active. The biological evaluation data revealed a total of seventeen potential inhibitors (out of twenty-two tested compounds) that exceeded our pre-defined 50\% inhibitory threshold of disrupting the HIV-1 IN-LEDGF/p75 interaction. Carbohydrazide 11e, with the para-methylphenyl group at the 5-position and the para-bromophenyl group at the $\mathrm{N}$-site of the imidazole moiety exhibited the highest inhibition of $89 \%$, which is close to the value obtained for reference compound MUT 101, with 90\% inhibition. Carboxylic acid 10k, with the para-methylphenyl ring at the 5-position and the para-chlorophenyl unit at the $\mathrm{N}$-site of the imidazole motif showed the second-highest level of inhibition, at $85 \%$. This was followed closely by carboxylic acid $\mathbf{1 0 d}$, with the metamethylphenyl and the para-bromophenyl motifs at the 5- and $N$ - sites, respectively, which showed $84 \%$ inhibition for disruption of the LEDGF/p75-IN interaction. Interestingly, these top 3 inhibitors all have a methyl substituent attached to the aryl ring at the 5-position of the imidazole motif, which is also present in the majority of known LEDGF/p75 interaction inhibitors. This indicates that the presence of the methyl substituent on the structure could be essential to the potency of the compound. The carboxylic acids, 10a (with the para-fluorophenyl and the para-bromophenyl motifs attached at the 5- and $\mathrm{N}$-positions, respectively) and 10e (with the para-methylphenyl and the para-bromophenyl units at the 5 - and $\mathrm{N}$-site) displayed the fourth and fifth best inhibition of $83 \%$ and $82 \%$, respectively. Compounds $\mathbf{1 0 b}, \mathbf{1 0 i}, \mathbf{1 0 j}, \mathbf{1 1} \mathrm{d}$, and $\mathbf{1 1 k}$ exhibited good overall inhibition, with percentage inhibitions ranging from $67 \%$ to $78 \%$ while chemical entities $10 \mathrm{c}, \mathbf{1 0 h}, \mathbf{1 1 a}, \mathbf{1 1 b}, \mathbf{1 1 h}$, and $11 \mathrm{i}$ disrupted the HIV-1 IN and LEDGF/p75 interaction by $50-59 \%$, demonstrating moderate inhibitory activity. Marginal percentage inhibition values of 17,35 , and $33 \%$ were observed for compounds 10f, 101, and $\mathbf{1 1} \mathbf{j}$, respectively, while compounds $\mathbf{1 1} \mathrm{g}$ and $\mathbf{1 1} \mathbf{i}$ were the only inactive molecules. According to the data, with the notable exception of $\mathbf{1 1 g}$ and 11i, the results did support the initial hypothesis that incorporation of carboxylic acid and carbohydrazide moieties onto the structure of hit 9 would have a significant impact on the binding capabilities of the compounds.

\subsubsection{Direct ELISA Assay}

The new compounds 10a-1, 11a,b, $\mathbf{1 1 d}, \mathbf{e}$, and $\mathbf{1 1} \mathbf{g}-\mathbf{1}$ were also examined for their ability to bind to divalent cations in the catalytic core of integrase using ELISA assays at $100 \mu \mathrm{M}$ concentration [59]. The assay was carried out in order to determine if the newly synthesized compounds act similarly to MUT 101 (3), which inhibits both IN-LEDGF interaction and IN strand transfer. A control compound, raltegravir, known to bind divalent metals within HIV-1 IN, was also tested alongside the test compounds. The experimental protocols were carried out in duplicate, and their relative percentage inhibitory values are shown in Table 3 and Figure 4. The data showed that most of the compounds showed no significant inhibition of strand transfer. Only three compounds, viz. 10a, 10l, and 11k, showed marginal percentage inhibition of $44 \%, 39 \%$, and $43 \%$, respectively, at $100 \mu \mathrm{M}$ compared to a 95\% inhibition for raltegravir at $10 \mu \mathrm{M}$ concentration as shown in Table 3. Thus, these results demonstrate that these two classes of compounds (10 and 11) may be specifically binding to the LEDGF/p75 binding site in HIV-1 integrase (Figure 4). 
Table 3. The HIV-1 IN-LEDGF/p75 inhibition activities observed for 1,5-diaryl-1H-imidazole-4carboxylic acids $\mathbf{1 0}$ and 1,5-diaryl- $1 H$-imidazole-4-carbohydrazides $\mathbf{1 1}$.

\begin{tabular}{|c|c|c|}
\hline \multirow[b]{2}{*}{ Compound } & \multicolumn{2}{|c|}{ Biochemical Assays } \\
\hline & $\begin{array}{l}\text { HIV-1 IN-LEDGF (\%) } \\
\text { Inhibition at } 100 \mu \mathrm{M} \\
(\text { AlphaScreen }\end{array}$ & $\begin{array}{c}\text { Strand Transfer Activity (\%) } \\
\text { Inhibition at } 100 \mu \mathrm{M} \text { (ELISA) }{ }^{1 *}\end{array}$ \\
\hline $10 a$ & $83 \pm 3.36$ & $44 \pm 1.13$ \\
\hline $10 \mathrm{~b}$ & $76 \pm 2.83$ & $24 \pm 3.39$ \\
\hline $10 \mathrm{c}$ & $51 \pm 4.16$ & 0 \\
\hline 10d & $84 \pm 0.29$ & $9 \pm 9.66$ \\
\hline $10 \mathrm{e}$ & $82 \pm 0.36$ & $2 \pm 9.00$ \\
\hline $10 f$ & $17 \pm 2.55$ & $16 \pm 4.89$ \\
\hline $10 \mathrm{~g}$ & $47 \pm 3.44$ & 0 \\
\hline $10 \mathrm{~h}$ & $54 \pm 10.05$ & 0 \\
\hline $10 \mathrm{i}$ & $74 \pm 9.29$ & 0 \\
\hline $10 \mathrm{j}$ & $78 \pm 8.99$ & $12 \pm 4.26$ \\
\hline 10k & $85 \pm 3.79$ & $1.4 \pm 6.07$ \\
\hline 101 & $35 \pm 2.26$ & $39 \pm 1.80$ \\
\hline $11 a$ & $51 \pm 9.16$ & 0 \\
\hline $11 b$ & $50 \pm 2.01$ & 0 \\
\hline 11d & $67 \pm 9.00$ & $1 \pm 5.89$ \\
\hline $11 e$ & $89 \pm 1.38$ & 0 \\
\hline $11 \mathrm{~g}$ & 0 & 0 \\
\hline $11 \mathrm{~h}$ & $59 \pm 3.22$ & 0 \\
\hline $11 \mathrm{i}$ & $50 \pm 9.61$ & 0 \\
\hline $11 \mathrm{j}$ & $33 \pm 6.89$ & $9 \pm$ \\
\hline 11k & $78 \pm 8.96$ & $43 \pm 6.20$ \\
\hline 111 & 0 & 0 \\
\hline MUT 101 & $90 \pm 0.52$ & - \\
\hline Raltegravir & - & $95 \pm 0.98$ \\
\hline
\end{tabular}

1* All compounds were tested at $100 \mu \mathrm{M}$ concentration in both the AlphaScreen and the ELISA assay unless otherwise stated.

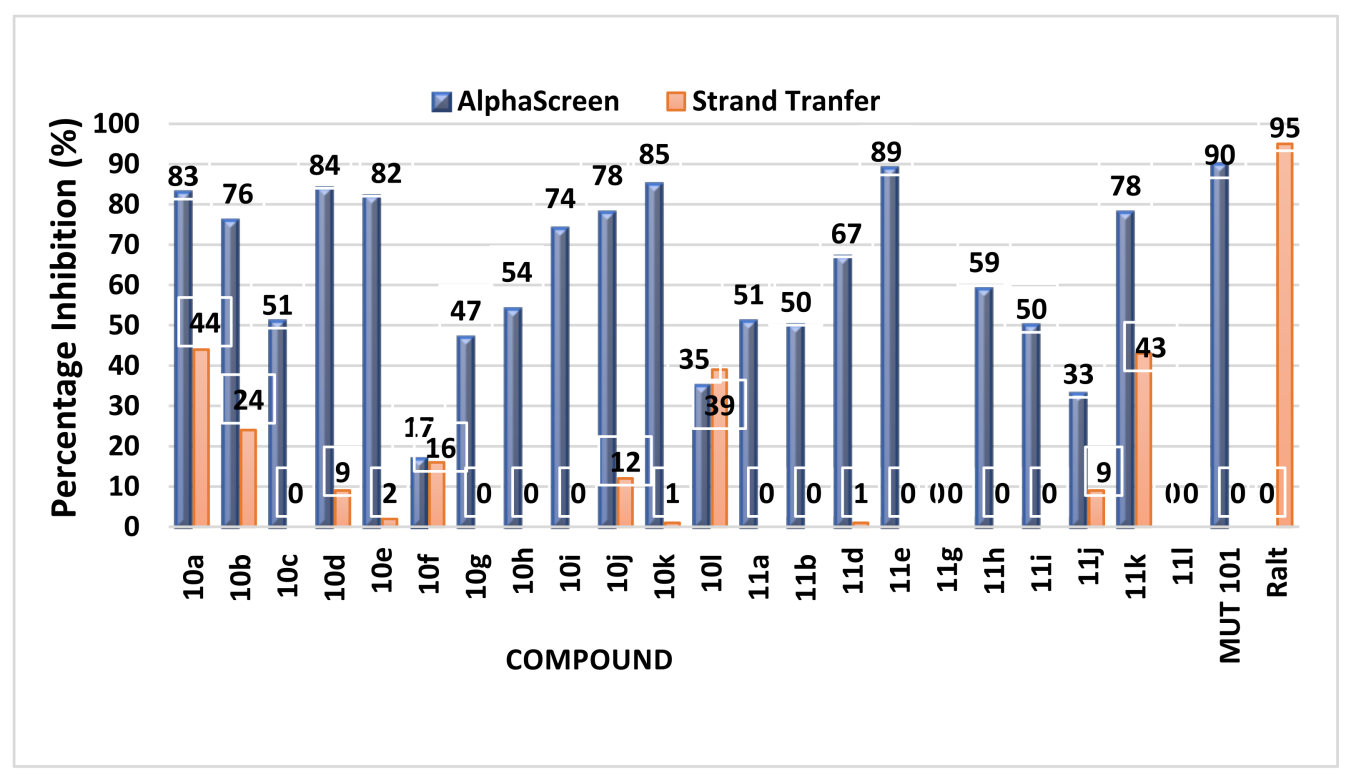

Figure 4. A comparison of carboxylic acid (10) and carbohydrazide (11) inhibition percentages in AlphaScreen $^{\mathrm{TM}}$ (blue) and ELISA (orange) assays at $100 \mu \mathrm{M}$. 


\subsubsection{Cytotoxicity and Antiviral Assays}

The newly synthesized compounds $\mathbf{1 0 a}-\mathbf{1}$ and $\mathbf{1 1 a}, \mathbf{b}, \mathbf{1 1 d}, \mathbf{e}$, and $\mathbf{1 1 g}-\mathbf{1}$ were further examined for cytotoxicity and antiviral activity using methods similar to those previously described [30]. The assays were performed in the metallothionein type 4 (MT-4) cells, a human cell line that is highly susceptible to HIV infection. Auranofin, a compound known for its toxicity to mammalian cells, was screened alongside the compounds. Cytotoxicity screening indicates the tolerance of the system to the compounds, as well as indicating the relative toxicity of these compounds to live cells [60]. Cytotoxicity results are represented in Table 4 . The data show that thirteen compounds are marginally toxic or non-toxic, having $\mathrm{CC}_{50}$ values of greater than or equal to $100 \mu \mathrm{M}$, while nine compounds exhibited slightly higher toxicity, with $\mathrm{CC}_{50}$ values of less than $100 \mu \mathrm{M}$. However, these scaffolds were not found to be overly toxic in comparison to the control, auranofin, which exhibited a $\mathrm{CC}_{50}$ value of $1.6 \mu \mathrm{M}$. The $\mathrm{CC}_{50}$ value of control compounds was comparable to the previously described $\mathrm{CC}_{50}$ values of $4.5 \mu \mathrm{M}$ against human HepG-2 human liver cells [61]. The results indicate that most of the compounds were tolerated well by the cells.

Table 4. The HIV-1 IN-LEDGF/p75 cell-based assay results for 1,5-diaryl-1H-imidazole-4-carboxylic acids 10 and 1,5-diaryl-1H-imidazole-4-carbohydrazide $\mathbf{1 1 .}$

\begin{tabular}{ccc}
\hline Compound & $\begin{array}{c}\text { Antiviral Activity at } \mathbf{1 0 0} \boldsymbol{\mu M}(\mathbf{\%}) \\
\text { HIV-1 }\end{array}$ & $\begin{array}{c}\text { Cybtype } \mathbf{C}^{\mathbf{1 *}} \\
\mathbf{C}_{\mathbf{5 0}}(\boldsymbol{\mu M} \mathbf{M})\end{array}$ \\
\hline $\mathbf{1 0 a}$ & 15 & 113.9 \\
$\mathbf{1 0 b}$ & 9 & 67.1 \\
$\mathbf{1 0 c}$ & 32 & 81.5 \\
$\mathbf{1 0 d}$ & 11 & 100.1 \\
$\mathbf{1 0 e}$ & 20 & 108.1 \\
$\mathbf{1 0 f}$ & 0 & 39.0 \\
$\mathbf{1 0 g}$ & 0 & 199.7 \\
$\mathbf{1 0 h}$ & 4 & 168.8 \\
$\mathbf{1 0 i}$ & 0 & $>200$ \\
$\mathbf{1 0 j}$ & 0 & 135.7 \\
$\mathbf{1 0 k}$ & 5 & 103.2 \\
$\mathbf{1 0 1}$ & 0 & $>200$ \\
$\mathbf{1 1 a}$ & 36 & $>200$ \\
$\mathbf{1 1 b}$ & 35 & 158.2 \\
$\mathbf{1 1 d}$ & 33 & 58.4 \\
$\mathbf{1 1 e}$ & 24 & 78.6 \\
$\mathbf{1 1 g}$ & 31 & $>200$ \\
$\mathbf{1 1 h}$ & 40 & 50.4 \\
$\mathbf{1 1 i}$ & 10 & 91.2 \\
$\mathbf{1 1 j}$ & 18 & 37.9 \\
$\mathbf{1 1 k}$ & 23 & 47.6 \\
$\mathbf{1 1 1}$ & 26 & 172.7 \\
\hline Raltegravir & 83 at $10 \mu \mathrm{M}$ & - \\
Auranofin & & 1.6 \\
\hline
\end{tabular}

1* All compounds tested at $100 \mu \mathrm{M}$ unless otherwise stated.

Finally, the compounds were evaluated for their capability to inhibit the viral outgrowth of the HIV-1 subtype C replicating in a cell-based antiviral assay at $100 \mu \mathrm{M}$ single dose concentration [62]. The antiviral percentage inhibition values of the evaluated compounds were calculated and are recorded in Table 4 . The antiviral percentage activities were found to range from low to moderate, with none found to be higher than $50 \%$ at $100 \mu \mathrm{M}$ compound concentration. Although compound $11 \mathrm{~h}$ was the best performer with an antiviral percentage of $40 \%$, its potency level was possibly induced by its toxicity of $50.4 \mu \mathrm{M}$ (Table 4). Taken together, compounds 11a, 11b, and 11g with $\mathrm{CC}_{50}$ values of $>200 \mu \mathrm{M}$, $158.4 \mu \mathrm{M}$, and $>200 \mu \mathrm{M}$, and antiviral percentage activities of $35 \%, 36 \%$, and $33 \%$, respectively, were considered to be promising scaffolds. This indicates that the selectivity of inhibition over toxicity for these compounds was favorable. Furthermore, it was interesting 
to observe that the compounds with marginal antiviral activities belong to the carbohydrazide family of compounds. Additionally, although, the antiviral percentage activities were minimal in comparison to raltegravir (tested at $10 \mu \mathrm{M}$ ), the results indicate that the inclusion of the carbohydrazide motif positively influenced the binding more than the carboxylic acid moiety.

\subsection{Multimerization Gel Assay as a Secondary Screening Assay}

Chemical covalent crosslinking of IN has been shown to stabilize the multimer forms when observed on SDS-PAGE [63]. This is particularly useful due to the disruption of these multimers due to SDS and reducing conditions in the gel. The IN cross-linking assay was performed as described previously [63]. This allowed for the capture of multimer forms and provided useful information in determining the effects that the compounds had on IN multimerization. Four compounds 11a, 11b, 11g, and 11h, exhibiting marginal antiviral percentage inhibitory activities were selected for the multimerization studies in a Western blot gel multimerization assay at concentrations of 50,100, and $200 \mu \mathrm{M}$. Compounds 11a, 11b, and 11h appear to cause an increase in higher-order oligomeric forms of IN as shown in Figure 5. There is a clear shift in the oligomeric equilibrium as a result of increasing concentrations of the compounds. These results indicate that the tested compounds cause multimerization, similar to previously described allosteric integrase inhibitors $[64,65]$.

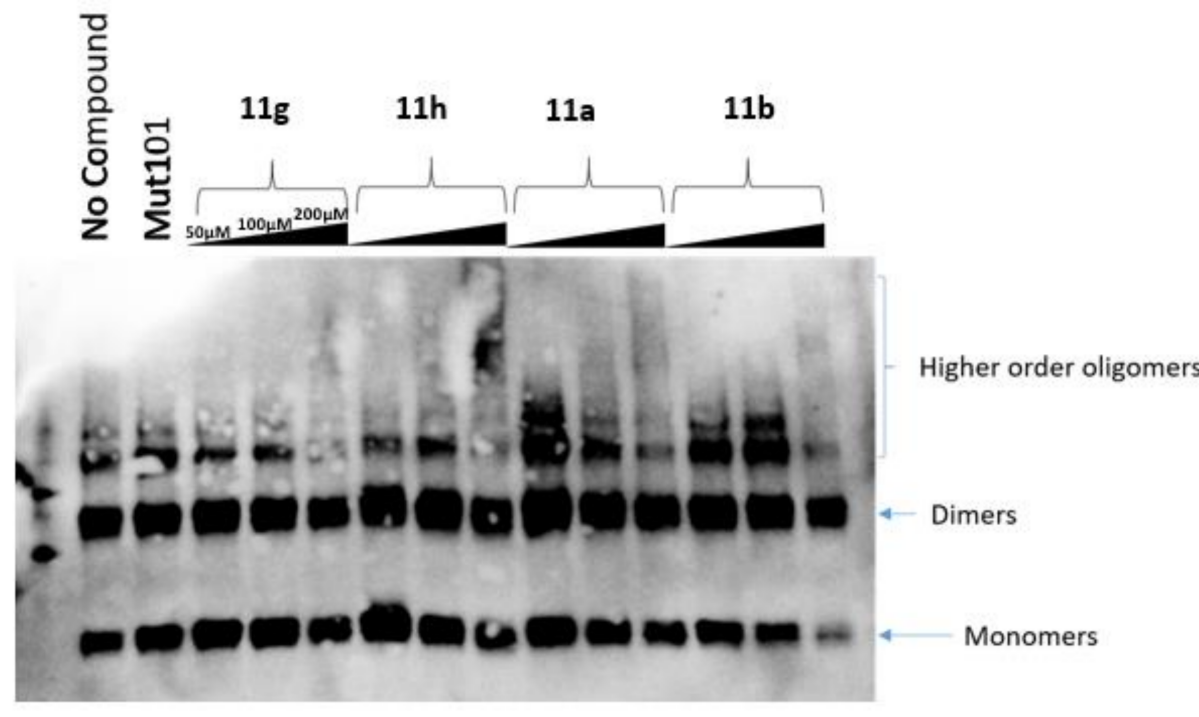

Figure 5. Western blot illustration of the multimerization caused by tested compounds. Compounds 11a, 11b, 11g, and 11h were selected for multimerization studies. Compounds were tested at $50 \mu \mathrm{M}$, $100 \mu \mathrm{M}$, and $200 \mu \mathrm{M}$. MUT101 was included as a control and tested at $50 \mu \mathrm{M}$ only. Between the no-compound control and MUT101, an increase of higher order IN forms is noticed. An increase in higher order IN oligomers is most pronounced in compounds 11a, 11b, and $\mathbf{1 1 h}$ and the equilibrium shifts to higher order forms as a factor of compound concentration.

\section{Experimental Protocols}

3.1. Chemistry

\subsubsection{Materials and Methods}

All commercially available reagents were purchased from Sigma Aldrich (Schnelldorf, Germany) and used without further purification. Dry solvents were used from an LCTech SP-1 Solvent Purification System (LC Technology Solutions Inc., Seabrook, New Hampshire, USA) and kept under argon. TLC was performed on pre-coated Merck silica gel F254 plates and viewed under UV light $(254 \mathrm{~nm})$ or following exposure to iodine vapor. Column chromatography was performed using Merck Silica gel 60 [particle size 0.040-0.063 mm (230-400 mesh)]. NMR spectra were recorded on a $400 \mathrm{MHz}$ Bruker Avance Spectrometer (Bruker BioSpin, Rheinstetten, Germany) at 298 K equipped with 
a BBI $5 \mathrm{~mm}$ probe and solvent calibrated. High-resolution mass spectra were recorded on an LC-MS system consisting of a Dionex Ultimate 3000 Rapid Separation LC system equipped with a C-18 pre-coated column and coupled to a MicrOTOF QII Bruker mass spectrometer (Bruker Daltonik GmbH, Bremen, Germany) fitted with an electrospray source and operating in positive mode. Sodium formate clusters were used for internal calibration. The chemical shifts $(\delta)$ are expressed in parts per million, according to the solvent residual peak resonances and calibrated using solvent signals $\left(7.26\left(\mathrm{CDCl}_{3}\right)\right.$ and 2.50 (DMSO- $\left.d_{6}\right)$ for ${ }^{1} \mathrm{H}$ NMR; $77.0\left(\mathrm{CDCl}_{3}\right)$ and $39.52\left(\mathrm{DMSO}-d_{6}\right)$ for ${ }^{13} \mathrm{C}$ NMR]. LC-MS grade acetonitrile and methanol were from Sigma Aldrich and water from a Milli-Q integral system. The MicrOTOF QII source parameters source were as follows: ESI source type; auto MSMS mode; mass range: $50-3000 \mathrm{Da}$; on positive polarity; endplate offset $-500 \mathrm{~V}$; capillary voltage $4500 \mathrm{~V}$; nebulizer $\mathrm{N}_{2} 1.2$ bar; dry heater $200^{\circ} \mathrm{C}$; drying $\mathrm{N}_{2}$ flow $8.0 \mathrm{~L} / \mathrm{min}$. The mass analyses were performed on Data Analysis software (Bruker Daltonics, Bremen, Germany). All melting points were obtained using a Stuart SMP10 melting point apparatus and are uncorrected.

\subsubsection{General Procedure for the Synthesis of N-Aryl-benzamides 14a-p}

To a stirred solution containing aniline $(14.4 \mathrm{mmol})$ and $\mathrm{Et}_{3} \mathrm{~N}(25.1 \mathrm{mmol})$ in EtOAc $(30 \mathrm{~mL})$ was added benzoyl chloride $(15.1 \mathrm{mmol})$ at $0{ }^{\circ} \mathrm{C}$. After addition, the resulting reaction mixture was allowed to warm to room temperature and stirred for $16 \mathrm{~h}$ (monitored by TLC). Upon completion, EtOAc $(20 \mathrm{~mL})$ was added, followed by washing with $1 \mathrm{M} \mathrm{HCl}$, saturated $\mathrm{NaHCO}_{3}$ and water. The organic layer was dried over anhydrous $\mathrm{MgSO}_{4}$, and the solvent evaporated and dried in vacuo to afford pure $\mathrm{N}$-aryl-benzamide derivatives [53].

3.1.3. General Procedure for the Synthesis of N-Aryl-benzimidoyl Chloride Intermediates 15a-n

A mixture of $N$-aryl-benzamide (1.0 molar equivalent) and thionyl chloride ( 6.0 molar equivalents) was heated to reflux until reaction completion ( $8 \mathrm{~h}$ ). Excess thionyl chloride was removed by co-evaporation with toluene to afford, after drying under high vacuum, diarylimidoyl chloride and were directly used in the next step without further purification [54-56].

N-(4-Bromophenyl)-4-fluorobenzimidoyl Chloride 15a

Yield: $2.01 \mathrm{~g}, 96 \%$ as a pale yellow solid; ${ }^{1} \mathrm{H} \mathrm{NMR}\left(400 \mathrm{MHz}, \mathrm{CDCl}_{3}\right) \delta 8.15-8.19(2 \mathrm{H}, \mathrm{m}$, $\mathrm{ArH}), 7.52(2 \mathrm{H}, \mathrm{d}, J=7.6 \mathrm{~Hz}, \mathrm{ArH}), 7.14(2 \mathrm{H}, \mathrm{d}, J=7.6 \mathrm{~Hz}, \mathrm{ArH}), 6.89(2 \mathrm{H}, \mathrm{d}, J=7.6 \mathrm{~Hz}, \mathrm{ArH})$; ${ }^{13} \mathrm{C}$ NMR $\left(101 \mathrm{MHz}, \mathrm{CDCl}_{3}\right) \delta 165.2\left(\mathrm{~d},{ }^{1} J_{\mathrm{CF}}=252 \mathrm{~Hz}, 4-\mathrm{FC}\right), 146.3,142.7(\mathrm{ArCCCl})$, $131.9(\mathrm{ArC}), 131.7\left(\mathrm{~d},{ }^{3} J_{\mathrm{CF}}=9 \mathrm{~Hz}, 2^{\prime}-\mathrm{C}\right.$ and $\left.66^{\prime}-\mathrm{C}\right), 131.3\left(\mathrm{~d},{ }^{4} J_{\mathrm{CF}}=3 \mathrm{~Hz}, 1^{\prime}-\mathrm{C}\right), 122.3$, 118.4 (ArC), $115.6\left(\mathrm{~d},{ }^{2} J_{\mathrm{CF}}=22 \mathrm{~Hz}, 3^{\prime}-\mathrm{C}\right.$ and $\left.5^{\prime}-\mathrm{C}\right)$.

$\mathrm{N}$-(4-Bromophenyl)-3-fluorobenzimidoyl Chloride $\mathbf{1 5 b}$

Yield: $1.84 \mathrm{~g}, 95 \%$ as pale yellow solid, ${ }^{1} \mathrm{H}$ NMR $\left(400 \mathrm{MHz}, \mathrm{CDCl}_{3}\right) \delta 7.94(1 \mathrm{H}$, $J=7.6 \mathrm{~Hz}, \mathrm{ArH}), 7.85(1 \mathrm{H}, J=9.6 \mathrm{~Hz}, \operatorname{ArH}), 7.52(2 \mathrm{H}, J=8.4 \mathrm{~Hz}, \mathrm{ArH}), 7.42(1 \mathrm{H}, \mathrm{dd}$, $J=7.2,7.6 \mathrm{~Hz}, \mathrm{ArH}), 7.24(1 \mathrm{H}, \mathrm{t}, J=8.0 \mathrm{~Hz}, \mathrm{ArH}), 6.90(2 \mathrm{H}, J=8.4 \mathrm{~Hz}, \mathrm{ArH}) ;{ }^{13} \mathrm{C}$ NMR $\left(101 \mathrm{MHz}, \mathrm{CDCl}_{3}\right) \delta 162.6\left(\mathrm{~d},{ }^{1} J_{\mathrm{CF}}=247 \mathrm{~Hz}, 3^{\prime}-\mathrm{CF}\right), 146.1(\mathrm{ArCCCl}), 142.2\left(\mathrm{~d},{ }^{4} J_{\mathrm{CF}}=3 \mathrm{~Hz}\right.$, $\left.6^{\prime}-\mathrm{C}\right), 137.2\left(\mathrm{~d},{ }^{3} J_{\mathrm{CF}}=8 \mathrm{~Hz}, 1^{\prime}-\mathrm{C}\right), 132.0,130.5,129.93(\mathrm{ArC}), 125.1\left(\mathrm{~d},{ }^{3} J_{\mathrm{CF}}=3 \mathrm{~Hz}, 5^{\prime}-\mathrm{C}\right)$, 122.3 (ArC), $119.2\left(\mathrm{~d},{ }^{3} J_{\mathrm{CF}}=22 \mathrm{~Hz}, 2^{\prime}-\mathrm{C}\right), 116.3\left(\mathrm{~d},{ }^{3} J_{\mathrm{CF}}=24 \mathrm{~Hz}, 4^{\prime}-\mathrm{C}\right)$.

$\mathrm{N}$-(4-Bromophenyl)-3-methoxybenzimidoyl Chloride 15c

Yield: $3.24 \mathrm{~g}, 98 \%$ as pale yellow solid; ${ }^{1} \mathrm{H}$ NMR $\left(400 \mathrm{MHz}, \mathrm{CDCl}_{3}\right) \delta 7.72(1 \mathrm{H}, \mathrm{d}$, $J=7.6 \mathrm{~Hz}, \mathrm{ArH}), 7.66(1 \mathrm{H}, \mathrm{s}, \mathrm{ArH}), 7.49(2 \mathrm{H}, \mathrm{d}, J=8.8 \mathrm{~Hz}, \mathrm{ArH}), 7.33(1 \mathrm{H}, \mathrm{t}, J=8.0 \mathrm{~Hz}$, $\mathrm{ArH}), 7.07(1 \mathrm{H}, \mathrm{d}, J=8 \mathrm{~Hz}, \mathrm{ArH}), 6.87(2 \mathrm{H}, \mathrm{d}, J=7.6 \mathrm{~Hz}, \mathrm{ArH}), 3.86\left(3 \mathrm{H}, \mathrm{s}, \mathrm{ArOCH}_{3}\right) ;{ }^{13} \mathrm{C}$ $\operatorname{NMR}\left(101 \mathrm{MHz}, \mathrm{CDCl}_{3}\right) \delta 159.6\left(\mathrm{ArCOCH}_{3}\right), 146.5,143.9(\mathrm{ArCCl}), 136.5,131.9,129.4,122.2$, 122.1, 118.7, 118.3 ( $\mathrm{ArCBr}), 114.0(\mathrm{ArC}), 55.5\left(\mathrm{ArCOCH}_{3}\right)$. 
N-(4-Bromophenyl)-3-methylbenzimidoyl Chloride 15d

Yield: $2.68 \mathrm{~g}$, $98 \%$ as pale yellow solid: ${ }^{1} \mathrm{H}$ NMR $\left(400 \mathrm{MHz}, \mathrm{CDCl}_{3}\right) \delta 7.97-8.03(2 \mathrm{H}, \mathrm{m}$, ArH) $7.56(2 \mathrm{H}, \mathrm{d}, J=8.4 \mathrm{~Hz}, \mathrm{ArH}), 7.41(2 \mathrm{H}, \mathrm{d}, J=4.0 \mathrm{~Hz}, \mathrm{ArH}), 6.943(2 \mathrm{H}, \mathrm{d}, J=8.4 \mathrm{~Hz}$, $\mathrm{ArH}), 2.24\left(3 \mathrm{H}, \mathrm{s}, \mathrm{ArCH}_{3}\right) ;{ }^{13} \mathrm{C} \mathrm{NMR}\left(101 \mathrm{MHz}, \mathrm{CDCl}_{3}\right) \delta$ 145.9, $144.2(\mathrm{ArCCl}), 138.2,135.0$, $130.4,129.8,128.9,128.3,126.7,121.9(\mathrm{ArCBr}), 24.1\left(\mathrm{ArCCH}_{3}\right)$.

$\mathrm{N}$-(4-Bromophenyl)-4-methylbenzimidoyl Chloride 15e

Yield: $2.74 \mathrm{~g}, 100 \%$ as pale yellow solid; ${ }^{1} \mathrm{H}$ NMR $\left(400 \mathrm{MHz}, \mathrm{CDCl}_{3}\right) \delta 7.98(2 \mathrm{H}, \mathrm{d}$, $J=8.4 \mathrm{~Hz}, \mathrm{ArH}), 7.45(2 \mathrm{H}, \mathrm{d}, J=8.4 \mathrm{~Hz}, \mathrm{ArH}), 7.21(2 \mathrm{H}, \mathrm{d}, J=8.0 \mathrm{~Hz}), 6.83(2 \mathrm{H}, \mathrm{d}, J=8.4 \mathrm{~Hz}$, $\mathrm{ArH}), 2.38\left(3 \mathrm{H}, \mathrm{s}, \mathrm{ArCH}_{3}\right) ;{ }^{13} \mathrm{C} \mathrm{NMR}\left(101 \mathrm{MHz}, \mathrm{CDCl}_{3}\right) \delta 146.7,144.2,143.1(\mathrm{ArCCl}), 132.0$, 131.6, 129.5, 129.3, 122.5, $118.2(\mathrm{ArC}), 21.5\left(\mathrm{ArCCH}_{3}\right)$.

$\mathrm{N}$-(4-Bromophenyl)benzimidoyl Chloride 15f

Yield: $2.56 \mathrm{~g}$, $96 \%$ as pale yellow solid: pale yellow solid; ${ }^{1} \mathrm{H}$ NMR $\left(400 \mathrm{MHz}, \mathrm{CDCl}_{3}\right)$ $\delta 8.16(2 \mathrm{H}, \mathrm{d}, J=7.6 \mathrm{~Hz}, \mathrm{ArH}), 7.47-7.59(5 \mathrm{H}, \mathrm{m}, \mathrm{ArH}), 6.91(2 \mathrm{H}, \mathrm{d}, J=8.8 \mathrm{~Hz}, \mathrm{ArH}) ;{ }^{13} \mathrm{C}$ $\operatorname{NMR}\left(101 \mathrm{MHz}, \mathrm{CDCl}_{3}\right) \delta 146.5,144.0$ (ArCCl), 135.2, 132.2, 132.0, 131.9, 129.4, 128.5, 122.3, $118.3(\operatorname{ArC})$.

$\mathrm{N}$-(4-Chlorophenyl)-4-fluorobenzimidoyl Chloride 15g

Yield: $3.00 \mathrm{~g}, 96 \%$ as pale yellow solid; ${ }^{1} \mathrm{H}$ NMR $\left(400 \mathrm{MHz}, \mathrm{CDCl}_{3}\right) \delta=8.11-8.14(2 \mathrm{H}$, $\mathrm{m}, \mathrm{ArH}), 7.33(2 \mathrm{H}, \mathrm{d}, J=8.8 \mathrm{~Hz}, \mathrm{ArH}) ; 7.09-7.13(3 \mathrm{H}, \mathrm{m}, \mathrm{ArH}) ; 7.12(1 \mathrm{H}, \mathrm{t}, J=7.8 \mathrm{~Hz}, \mathrm{ArH})$, $6.85(2 \mathrm{H}, \mathrm{d}, J=8.4 \mathrm{~Hz}, \mathrm{ArH}) ;{ }^{13} \mathrm{C} \mathrm{NMR}\left(101 \mathrm{MHz}, \mathrm{CDCl}_{3}\right) \delta=165.2\left({ }^{1} J_{\mathrm{CF}}=248 \mathrm{~Hz}, 4^{\prime}-\mathrm{FC}\right)$, $145.7,142.7(\mathrm{ArCCCl}), 131.6\left({ }^{3} J_{\mathrm{CF}}=9 \mathrm{~Hz}, 2^{\prime}-\mathrm{C}\right.$ and $\left.6^{\prime}-\mathrm{C}\right), 131.3\left({ }^{4} J_{\mathrm{CF}}=3 \mathrm{~Hz}, \mathrm{C}-1^{\prime}\right), 130.6$, $129.0,122.0,115.4\left(\mathrm{~d},{ }^{3} J_{\mathrm{CF}}=22 \mathrm{~Hz}, 3^{\prime}-\mathrm{C}\right.$ and $\left.5^{\prime}-\mathrm{C}\right)$.

$\mathrm{N}$-(4-Chlorophenyl)-3-fluorobenzimidoyl Chloride $\mathbf{1 5 h}$

Yield: $3.06 \mathrm{~g}$, $98 \%$ as pale yellow solid; ${ }^{1} \mathrm{H}$ NMR $\left(400 \mathrm{MHz}, \mathrm{CDCl}_{3}\right) \delta 8.83(2 \mathrm{H}, J=7.6 \mathrm{~Hz}$, $\mathrm{ArH}), 7.74(1 \mathrm{H}, \mathrm{d}, J=10.0 \mathrm{~Hz} \mathrm{ArH}), 7.27-7.36(3 \mathrm{H}, \mathrm{m}, \mathrm{ArH}), 6.85(2 \mathrm{H}, J=8.4 \mathrm{~Hz}, \mathrm{ArH}) ;{ }^{13} \mathrm{C}$ $\operatorname{NMR}\left(101 \mathrm{MHz}, \mathrm{CDCl}_{3}\right) \delta 162.5\left(\mathrm{~d},{ }^{1} J_{\mathrm{CF}}=247 \mathrm{~Hz}, 3^{\prime}-\mathrm{CF}\right), 146.1,142.5\left(\mathrm{~d},{ }^{4} J_{\mathrm{CF}}=3.0 \mathrm{~Hz}, 6^{\prime}-\mathrm{C}\right)$, $137.3\left(\mathrm{~d},{ }^{3} J_{\mathrm{CF}}=8 \mathrm{~Hz}, \mathrm{1}^{\prime}-\mathrm{C}\right), 132.0,130.0,129.3(\mathrm{ArC}), 125.1\left(\mathrm{~d},{ }^{3} J_{\mathrm{CF}}=3.0 \mathrm{~Hz}, 5^{\prime}-\mathrm{C}\right), 122.1(\mathrm{ArC})$, $119.1\left(\mathrm{~d},{ }^{3} J_{\mathrm{CF}}=22 \mathrm{~Hz}, 2^{\prime}-\mathrm{C}\right), 116.2\left(\mathrm{~d},{ }^{3} J_{\mathrm{CF}}=24 \mathrm{~Hz}, 4^{\prime}-\mathrm{C}\right)$.

$\mathrm{N}$-(4-Chlorophenyl)-3-methoxybenzimidoyl Chloride 15i

Yield: $3.14 \mathrm{~g}, 97 \%$ as pale yellow solid; ${ }^{1} \mathrm{H}$ NMR $\left(400 \mathrm{MHz}, \mathrm{CDCl}_{3}\right) \delta 7.70(2 \mathrm{H}$, $\mathrm{d}, J=7.6 \mathrm{~Hz}, \mathrm{ArH}), 7.66(1 \mathrm{H}, \mathrm{s}, \mathrm{ArH}), 7.32-7.34(3 \mathrm{H}, \mathrm{m}, \mathrm{ArH}), 7.05(1 \mathrm{H}, \mathrm{d}, J=8.4 \mathrm{~Hz}$, $\mathrm{ArH}), 6.92(2 \mathrm{H}, \mathrm{d}, J=7.6 \mathrm{~Hz}, \mathrm{ArH}), 3.82\left(3 \mathrm{H}, \mathrm{s}, \mathrm{ArOCH}_{3}\right) ;{ }^{13} \mathrm{C} \mathrm{NMR}\left(101 \mathrm{MHz}, \mathrm{CDCl}_{3}\right)$ $\delta 159.5\left(\mathrm{ArCOCH}_{3}\right), 145.9,143.8(\mathrm{ArCCl}), 136.4,130.4$. 129.3, 128.9, 122.0, 121.8, 118.5, $113.9(\mathrm{ArC}), 55.5\left(\mathrm{ArCOCH}_{3}\right)$.

$\mathrm{N}$-(4-Chlorophenyl)-3-methylbenzimidoyl Chloride 15j

Yield: $3.02 \mathrm{~g}, 98 \%$ as pale yellow solid; ${ }^{1} \mathrm{H}$ NMR $\left(400 \mathrm{MHz}, \mathrm{CDCl}_{3}\right): \delta=8.05(2 \mathrm{H}$, $\mathrm{t}, J=6.0 \mathrm{~Hz}, \mathrm{ArH}), 7.48-7.79(4 \mathrm{H}, \mathrm{m}, \mathrm{ArH}), 7.94(2 \mathrm{H}, \mathrm{d}, J=8.4 \mathrm{~Hz}, \mathrm{ArH}) ; 2.52(3 \mathrm{H}, \mathrm{s}$, $\mathrm{ArCH}_{3}$ ) [54].

N-(4-Chlorophenyl)-4-methylbenzimidoyl Chloride 15k

Yield: $2.93 \mathrm{~g}$, $95 \%$ as pale yellow solid; ${ }^{1} \mathrm{H}$ NMR $\left(400 \mathrm{MHz}, \mathrm{CDCl}_{3}\right): \delta=8.00(2 \mathrm{H}$, $\mathrm{d}, J=7.6 \mathrm{~Hz}, \mathrm{ArH}), 7.30(2 \mathrm{H}, \mathrm{d}, J=8.4 \mathrm{~Hz}, \mathrm{ArH}), 7.21(2 \mathrm{H}, \mathrm{d}, J=8.0, \mathrm{ArH}) ; 6.91(2 \mathrm{H}, \mathrm{d}$, $J=8.0 \mathrm{~Hz},) ; 2.39\left(3 \mathrm{H}, \mathrm{s}, \mathrm{ArCH}_{3}\right) ;{ }^{13} \mathrm{C} \mathrm{NMR}\left(101 \mathrm{MHz}, \mathrm{CDCl}_{3}\right) \delta$ 146.0, $144.0(\mathrm{ArCCl}), 142.9$, $132.4,130.3,129.4,128.9,122.0(\mathrm{ArC}), 21.4\left(\mathrm{ArCCH}_{3}\right)$.

$\mathrm{N}$-(4-Chlorophenyl)benzimidoyl Chloride 151

Yield: $2.68 \mathrm{~g}, 98 \%$ as pale yellow solid; ${ }^{1} \mathrm{H}$ NMR $\left(400 \mathrm{MHz}, \mathrm{CDCl}_{3}\right) \delta 8.19(2 \mathrm{H}, \mathrm{d}$, $J=7.6 \mathrm{~Hz}, \mathrm{ArH}), 7.39-7.60(5 \mathrm{H}, \mathrm{m}, \mathrm{ArH}), 6.99(2 \mathrm{H}, \mathrm{d}, J=8.4 \mathrm{~Hz}, \mathrm{ArH}) ;{ }^{13} \mathrm{C} \mathrm{NMR}(101 \mathrm{MHz}$, $\left.\mathrm{CDCl}_{3}\right) \delta 145.9,144.0$ (ArCCl), 135.2, 132.1, 130.5, 129.4, 128.9, 128.4, 121.9 (ArC). 
$\mathrm{N}$-(2.4-Dimethylphenyl)-4-fluorobenzimidoyl Chloride 15m

Yield: $2.95 \mathrm{~g}, 100 \%$ as pale yellow solid; ${ }^{1} \mathrm{H}$ NMR $\left(400 \mathrm{MHz}, \mathrm{CDCl}_{3}\right) \delta 8.21-8.24(2 \mathrm{H}$, $\mathrm{m}, \mathrm{ArH}), 7.10-7.20(5 \mathrm{H}, \mathrm{m}, \mathrm{ArH}), 6.8(1 \mathrm{H}, \mathrm{d}, J=8.2 \mathrm{~Hz}, \mathrm{ArH}), 2.37$ and $2.20\left(2 \times \mathrm{ArCCH}_{3}\right)$; ${ }^{13} \mathrm{C}$ NMR $\left(101 \mathrm{MHz}, \mathrm{CDCl}_{3}\right) \delta 165.2\left(\mathrm{~d},{ }^{1} J_{\mathrm{CF}}=253 \mathrm{~Hz}, 4-\mathrm{FC}\right), 143.9,141.6(\mathrm{ArCCCl}), 134.7$, $131.7\left(\mathrm{~d},{ }^{3} J_{\mathrm{CF}}=9 \mathrm{~Hz}, 2^{\prime}-\mathrm{C}\right.$ and $\left.6^{\prime}-\mathrm{C}\right), 131.1,128.4,126.8,119.29(\mathrm{ArC}), 115.9\left(\mathrm{~d},{ }^{3} J_{\mathrm{CF}}=22 \mathrm{~Hz}\right.$, $\mathrm{C}-3^{\prime}$ and $\left.\mathrm{C}-6^{\prime}\right), 20.9$ and $17.8\left(2 \times \mathrm{ArCCH}_{3}\right)$.

N-(2.4-Dimethylphenyl)-3-methoxybenzimidoyl Chloride 15n

Yield: $2.68 \mathrm{~g}, 98 \%$ as pale yellow solid; ${ }^{1} \mathrm{H}$ NMR $\left(400 \mathrm{MHz}, \mathrm{CDCl}_{3}\right) \delta 7.80(1 \mathrm{H}, \mathrm{d}$, $J=8.2 \mathrm{~Hz}, \mathrm{ArH}), 7.76(1 \mathrm{H}, \mathrm{t}, J=5.6 \mathrm{~Hz}, \mathrm{ArH}), 7.39(1 \mathrm{H}, \mathrm{t}, J=5.6 \mathrm{~Hz}, \mathrm{ArH}), 7.07-7.14(3 \mathrm{H}$, $\mathrm{m}, \mathrm{ArH}), 6.82(1 \mathrm{H}, \mathrm{d}, J=7.6 \mathrm{~Hz}, \mathrm{ArH}), 3.91\left(3 \mathrm{H}, \mathrm{s}, \mathrm{ArOCH}_{3}\right), 2.37$ and $2.20(6 \mathrm{H}, 2 \times \mathrm{s}$, $\left.2 \times \mathrm{ArCH}_{3}\right) ;{ }^{13} \mathrm{C} \mathrm{NMR}\left(101 \mathrm{MHz}, \mathrm{CDCl}_{3}\right) \delta 159.6\left(\mathrm{ArCOCH}_{3}\right), 143.9(\mathrm{ArCCl}), 143.0,136.6$, 134.6, 131.0, 129.3, 128.3, 126.8, 122.0, 119.2, 118.3, $114.0(\mathrm{ArC}), 55.4\left(\mathrm{ArCOCH}_{3}\right), 20.9$ and $17.7\left(2 \times \mathrm{ArCCH}_{3}\right)$.

3.1.4. General Procedure for the Synthesis of Ethyl 1,5-Diaryl-1H-imidazoyl Carboxylates 17a-1

A mixture of ethyl isocyanoacetate $\mathbf{1 6}(5.1 \mathrm{mmol})$ and DBU $(5.1 \mathrm{mmol})$ in anhydrous THF ( $25 \mathrm{~mL}$ ) was cooled to $-78{ }^{\circ} \mathrm{C}$ under argon. N-aryl-benzimidoyl chloride 15 (5.1 mmol) was then added under a flow of argon and the resulting reaction mixture was allowed to warm to room temperature. After $48 \mathrm{~h}$, the reaction was quenched with saturated sodium bicarbonate and extracted with EtOAc, washed with brine, dried over anhydrous $\mathrm{MgSO}_{4}$, and concentrated in vacuo. The crude product was purified by column chromatography, (eluting with EtOAc/ Hexane (1:4), followed by 100\% EtOAc) to afford the desired ethyl 1,5-diaryl-1H-imidazole carboxylate 17.

Ethyl 1-(4-Bromophenyl)-5-(4-fluorophenyl)-1H-imidazole-4-carboxylate 17a

Yield: $1.27 \mathrm{~g}, 64 \%$ as a pale yellow solid; $\mathrm{mp}: 145-147^{\circ} \mathrm{C} ;{ }^{1} \mathrm{H}$ NMR $\left(400 \mathrm{MHz}, \mathrm{CDCl}_{3}\right)$ : $\delta=7.69(1 \mathrm{H}, \mathrm{s}, 2-\mathrm{CH}), 7.44(2 \mathrm{H}, \mathrm{d}, J=8.8 \mathrm{~Hz}, \mathrm{ArH}), 7.17(2 \mathrm{H}, \mathrm{m}, \mathrm{ArH}), 6.92-6.99(4 \mathrm{H}, \mathrm{m}$, $\mathrm{ArH}), 4.23\left(2 \mathrm{H}, \mathrm{q}, J=7.2 \mathrm{~Hz}, \mathrm{OCH}_{2} \mathrm{CH}_{3}\right), 1.24\left(3 \mathrm{H}, \mathrm{t}, J=7.2 \mathrm{~Hz}, \mathrm{OCH}_{2} \mathrm{CH}_{3}\right) ;{ }^{13} \mathrm{C} \mathrm{NMR}$ $\left(101 \mathrm{MHz}, \mathrm{CDCl}_{3}\right): \delta=162.9\left(\mathrm{~d},{ }^{1} J_{\mathrm{CF}}=251 \mathrm{~Hz}, \mathrm{FC}-4^{\prime}\right), 162.7(\mathrm{C}=\mathrm{O}), 137.4(\mathrm{C}-2), 136.9,134.4$, $132.7\left(\mathrm{~d},{ }^{3} J_{\mathrm{CF}}=10 \mathrm{~Hz}, \mathrm{C}-2^{\prime}\right.$ and $\left.\mathrm{C}-6^{\prime}\right), 130.9,127.3,123.8\left(\mathrm{~d},{ }^{4} J_{\mathrm{CF}}=3 \mathrm{~Hz}, \mathrm{C}-1^{\prime}\right), 122.8(\mathrm{ArCBr})$, $115.2\left(\mathrm{~d},{ }^{3} J_{\mathrm{CF}}=22 \mathrm{~Hz}, \mathrm{C}-3^{\prime}\right.$ and $\left.\mathrm{C}-5^{\prime}\right), 60.6\left(\mathrm{OCH}_{2} \mathrm{CH}_{3}\right), 14.2\left(\mathrm{OCH}_{2} \mathrm{CH}_{3}\right)$; HRMS (ESI-TOF) $m / z:[\mathrm{M}+\mathrm{H}]^{+}$Calcd. for $\mathrm{C}_{18} \mathrm{H}_{15}{ }^{79} \mathrm{BrFN}_{2} \mathrm{O}_{2}$ 389.0295, found 389.0301.

Ethyl 1-(4-Bromophenyl)-5-(3-fluorophenyl)-1H-imidazole-4-carboxylate 17b

Yield: $1.15 \mathrm{~g}, 58 \%$ as a pale yellow solid; $\mathrm{mp}: 129-131^{\circ} \mathrm{C} ;{ }^{1} \mathrm{H} \mathrm{NMR}\left(400 \mathrm{MHz}, \mathrm{CDCl}_{3}\right)$ $\delta 7.74(1 \mathrm{H}, \mathrm{s}, 2-\mathrm{CH}), 7.48(2 \mathrm{H}, \mathrm{d}, J=8 \mathrm{~Hz}, \mathrm{ArH}), 7.28-7.31(1 \mathrm{H}, \mathrm{m}, \mathrm{ArH}), 6.98-7.08(5 \mathrm{H}$, $\mathrm{m}, \mathrm{ArH}), 4.28\left(2 \mathrm{H}, \mathrm{q}, J=7 \mathrm{~Hz}, \mathrm{OCH}_{2} \mathrm{CH}_{3}\right), 1.28\left(3 \mathrm{H}, \mathrm{t}, J=7 \mathrm{~Hz}, \mathrm{OCH}_{2} \mathrm{CH}_{3}\right) ;{ }^{13} \mathrm{C} \mathrm{NMR}$ $\left(101 \mathrm{MHz}, \mathrm{CDCl}_{3}\right) \delta 162.4(\mathrm{C}=\mathrm{O}), 161.9\left(\mathrm{~d},{ }^{1} J_{\mathrm{CF}}=247 \mathrm{~Hz}, \mathrm{FC}-3^{\prime}\right), 137.5(\mathrm{C}-2), 136.3(\mathrm{~d}$, $\left.{ }^{4} J_{\mathrm{CF}}=2 \mathrm{~Hz}, \mathrm{C}-6^{\prime}\right), 134.7,132.6,131.1,129.8\left(\mathrm{~d},{ }^{3} J_{\mathrm{CF}}=9 \mathrm{~Hz}, \mathrm{C}-5^{\prime}\right), 129.6,129.5,127.7(\mathrm{~d}$, $\left.{ }^{3} J_{C F}=3 \mathrm{~Hz}, \mathrm{C}-1^{\prime}\right), 122.7(\mathrm{ArC}), 117.7\left(\mathrm{~d},{ }^{3} J_{\mathrm{CF}}=23 \mathrm{~Hz}, \mathrm{C}-4^{\prime}\right), 115.8\left(\mathrm{~d},{ }^{3} J_{C F}=22 \mathrm{~Hz}\right.$, C-2' $), 60.5\left(\mathrm{OCH}_{2} \mathrm{CH}_{3}\right), 14.1\left(\mathrm{OCH}_{2} \mathrm{CH}_{3}\right)$; HRMS (ESI-TOF) $m / z$ : $[\mathrm{M}+\mathrm{H}]^{+}$Calcd. for $\mathrm{C}_{18} \mathrm{H}_{15}{ }^{79} \mathrm{BrFN}_{2} \mathrm{O}_{2}$ 389.0295, found 389.0301 .

Ethyl 1-(4-Bromophenyl)-5-(3-methoxyphenyl)-1H-imidazole-4-carboxylate 17c

Yield: $368 \mathrm{mg}, 18 \%$ as a yellow solid; ${ }^{1} \mathrm{H}$ NMR $\left(400 \mathrm{MHz}, \mathrm{CDCl}_{3}\right) \delta 7.70(1 \mathrm{H}, \mathrm{s}, 2-\mathrm{CH})$, $7.28(2 \mathrm{H}, \mathrm{d}, J=8.4 \mathrm{~Hz}, \mathrm{ArH}), 7.18(1 \mathrm{H}, \mathrm{t}, J=8.0 \mathrm{~Hz}, \mathrm{ArH}), 7.01(2 \mathrm{H}, \mathrm{d}, J=8.4 \mathrm{~Hz}, \mathrm{ArH})$, 6.77-6.87 (3H, m, ArH), $4.25\left(2 \mathrm{H}, \mathrm{q}, J=7.2 \mathrm{~Hz}, \mathrm{OCH}_{2} \mathrm{CH}_{3}\right), 3.70\left(3 \mathrm{H}, \mathrm{s}, \mathrm{ArOCH}_{3}\right), 1.25(3 \mathrm{H}$, $\left.\mathrm{t}, \mathrm{J}=7.0 \mathrm{~Hz}, \mathrm{OCH}_{2} \mathrm{CH}_{3}\right) ;{ }^{13} \mathrm{C} \mathrm{NMR}\left(101 \mathrm{MHz}, \mathrm{CDCl}_{3}\right) \delta 162.6(\mathrm{C}=\mathrm{O}), 159.0\left(\mathrm{ArCOCH}_{3}\right)$, 137.6 (C-2), 137.2, 134.7, 132.6, 130.9, 129.1, 127.1, 123.1, 122.5, 119.3, 116.5, 114.5 (ArC), $60.5\left(\mathrm{OCH}_{2} \mathrm{CH}_{3}\right), 55.1\left(\mathrm{ArCOCH}_{3}\right), 14.1\left(\mathrm{OCH}_{2} \mathrm{CH}_{3}\right) ; \mathrm{HRMS}$ (ESI-TOF) $m / z:[\mathrm{M}+\mathrm{H}]^{+}$ Calcd. for $\mathrm{C}_{19} \mathrm{H}_{18}{ }^{79} \mathrm{BrN}_{2} \mathrm{O}_{3}$ 401.0495, found 401.0487. 
Ethyl 1-(4-Bromophenyl)-5-(3-methylphenyl)-1H-imidazole-4-carboxylate 17d

Yield: $591 \mathrm{mg}, 30 \%$ as a white solid; $\mathrm{mp}: 185-187^{\circ} \mathrm{C} ;{ }^{1} \mathrm{H}$ NMR $\left(400 \mathrm{MHz}, \mathrm{CDCl}_{3}\right)$ $\delta 7.69(1 \mathrm{H}, \mathrm{s}, 2-\mathrm{CH}), 7.43(2 \mathrm{H}, \mathrm{d}, J=8.4 \mathrm{~Hz}, \mathrm{ArH}), 7.13-7.19(2 \mathrm{H}, \mathrm{m}, \mathrm{ArH}), 7.05(1 \mathrm{H}, \mathrm{s}$, $\mathrm{ArH}), 6.93-6.98(3 \mathrm{H}, \mathrm{m}, \mathrm{ArH}), 4.25\left(2 \mathrm{H}, \mathrm{q}, J=7.2 \mathrm{~Hz}, \mathrm{OCH}_{2} \mathrm{CH}_{3}\right), 2.27\left(3 \mathrm{H}, \mathrm{s}, \mathrm{ArCH}_{3}\right)$, $1.24\left(3 \mathrm{H}, \mathrm{t}, J=7 \mathrm{~Hz}, \mathrm{OCH}_{2} \mathrm{CH}_{3}\right) ;{ }^{13} \mathrm{C}$ NMR $\left(101 \mathrm{MHz}, \mathrm{CDCl}_{3}\right) \delta 162.6(\mathrm{C}=\mathrm{O}), 138.0$, 137.6 (C-2), 137.2, 134.6, 132.5, 131.3, 130.7, 129.7, 128.0, 127.8, 127.7, 127.1, 122.4 (ArC), $60.4\left(\mathrm{OCH}_{2} \mathrm{CH}_{3}\right), 21.3\left(\mathrm{ArCCH}_{3}\right), 14.1\left(\mathrm{OCH}_{2} \mathrm{CH}_{3}\right) ; \mathrm{HRMS}$ (ESI-TOF) $\mathrm{m} / z:[\mathrm{M}+\mathrm{H}]^{+}$Calcd. for $\mathrm{C}_{19} \mathrm{H}_{18}{ }^{79} \mathrm{BrN}_{2} \mathrm{O}_{2}$ 385.0546, found 385.0557.

Ethyl 1-(4-Bromophenyl)-5-(4-methylphenyl)- $1 \mathrm{H}$-imidazole-4-carboxylate 17e

Yield: $690 \mathrm{mg}, 35 \%$ as a yellow solid; mp: $142-144{ }^{\circ} \mathrm{C} ;{ }^{1} \mathrm{H}$ NMR $\left(400 \mathrm{MHz}, \mathrm{CDCl}_{3}\right) \delta$ $7.69(1 \mathrm{H}, \mathrm{s}, 2-\mathrm{CH}), 7.28(2 \mathrm{H}, \mathrm{d}, J=9.0 \mathrm{~Hz}, \mathrm{ArH}), 7.10(4 \mathrm{H}, \mathrm{m}, \mathrm{ArH}), 6.99(2 \mathrm{H}, \mathrm{d}, J=8.0 \mathrm{~Hz}$, $\mathrm{ArH}), 4.26\left(2 \mathrm{H}, \mathrm{q}, J=7.0 \mathrm{~Hz}, \mathrm{OCH}_{2} \mathrm{CH}_{3}\right), 2.32\left(3 \mathrm{H}, \mathrm{s}, \mathrm{ArCH}_{3}\right), 1.27(3 \mathrm{H}, \mathrm{t}, J=7.0 \mathrm{~Hz}$, $\left.\mathrm{OCH}_{2} \mathrm{CH}_{3}\right) ;{ }^{13} \mathrm{C}$ NMR $\left(101 \mathrm{MHz}, \mathrm{CDCl}_{3}\right) \delta 162.7(\mathrm{C}=\mathrm{O}), 139.5,138.1(\mathrm{ArC}), 137.6(\mathrm{C}-2)$, 134.7, 132.0, 131.4, 130.8, 129.8, 127.8, 127.1, $122.4(\mathrm{ArC}), 60.4\left(\mathrm{OCH}_{2} \mathrm{CH}_{3}\right), 21.3$ (ArCCH3), $14.2\left(\mathrm{OCH}_{2} \mathrm{CH}_{3}\right)$; HRMS (ESI-TOF) $m / z$ : $[\mathrm{M}+\mathrm{H}]^{+}$Calcd. for $\mathrm{C}_{18} \mathrm{H}_{18}{ }^{79} \mathrm{BrFN}_{2} \mathrm{O}_{2}$ calc. 385.0546, found. 385.0548 .

Ethyl 1-(4-Bromophenyl)-5-phenyl-1H-imidazole-4-carboxylate 17f

Yield: $417 \mathrm{mg}, 22 \%$ as a white solid; $\mathrm{mp}: 138-140{ }^{\circ} \mathrm{C} ;{ }^{1} \mathrm{H} \mathrm{NMR}\left(400 \mathrm{MHz}, \mathrm{CDCl}_{3}\right) \delta$ $7.70(1 \mathrm{H}, \mathrm{s}, 2-\mathrm{CH}), 7.46(2 \mathrm{H}, \mathrm{d}, J=8.4 \mathrm{~Hz}, \mathrm{ArH}), 7.28-7.33(3 \mathrm{H}, \mathrm{m}, \mathrm{ArH}), 7.21-7.23(2 \mathrm{H}, \mathrm{d}$, $J=6.8 \mathrm{~Hz}, \mathrm{ArH}), 6.93(2 \mathrm{H}, \mathrm{d}, \mathrm{J}=8.4 \mathrm{~Hz}, \mathrm{ArH}), 4.26\left(2 \mathrm{H}, \mathrm{q}, J=7.2 \mathrm{~Hz}, \mathrm{OCH}_{2} \mathrm{CH}_{3}\right), 1.25(3 \mathrm{H}, \mathrm{t}$, $\left.J=7.2 \mathrm{~Hz}, \mathrm{OCH}_{2} \mathrm{CH}_{3}\right) ;{ }^{13} \mathrm{C}$ NMR $\left(101 \mathrm{MHz}, \mathrm{CDCl}_{3}\right) \delta 162.7(\mathrm{C}=\mathrm{O}), 137.9(\mathrm{C}-2), 137.3,134.6$, 132.6, 130.8, 130.7, 129.0, 128.0, 127.9, 127.2, $122.5(\mathrm{ArC}), 60.5\left(\mathrm{OCH}_{2} \mathrm{CH}_{3}\right), 14.2\left(\mathrm{OCH}_{2} \mathrm{CH}_{3}\right)$; HRMS (ESI-TOF) $m / z$ : [M+H] ${ }^{+}$Calcd. for $\mathrm{C}_{16} \mathrm{H}_{16}{ }^{79} \mathrm{BrN}_{2} \mathrm{O}_{2} 371.0390$, found 371.0398.

Ethyl 1-(4-Chlorophenyl)-5-(4-fluorophenyl)-1 $\mathrm{H}$-imidazole-4-carboxylate $\mathbf{1 7 g}$

Yield: $1.28 \mathrm{~g}, 72 \%$ as a yellow solid; $\mathrm{mp}: 146-148{ }^{\circ} \mathrm{C} ;{ }^{1} \mathrm{H} \mathrm{NMR}\left(400 \mathrm{MHz}, \mathrm{CDCl}_{3}\right) \delta$ $7.69(1 \mathrm{H}, \mathrm{s}, 2-\mathrm{CH}), 7.29(2 \mathrm{H}, \mathrm{d}, J=8.0 \mathrm{~Hz}, \mathrm{ArH}), 7.18(2 \mathrm{H}, J=7.0 \mathrm{~Hz}, \mathrm{ArH}), 6.96-7.00(4 \mathrm{H}$, $\mathrm{m}, \mathrm{ArH}), 4.25\left(2 \mathrm{H}, \mathrm{q}, J=7.0 \mathrm{~Hz}, \mathrm{OCH}_{2} \mathrm{CH}_{3}\right), 1.26\left(3 \mathrm{H}, \mathrm{t}, J=7.0 \mathrm{~Hz}, \mathrm{OCH}_{2} \mathrm{CH}_{3}\right) ;{ }^{13} \mathrm{C}$ NMR $\left(101 \mathrm{MHz}, \mathrm{CDCl}_{3}\right) \delta 162.8\left(\mathrm{~d},{ }^{1} J_{\mathrm{CF}}=251 \mathrm{~Hz}, \mathrm{FC}-4^{\prime}\right), 162.6(\mathrm{C}=\mathrm{O}), 137.4(\mathrm{C}-2), 136.9,134.7$, 133.8 (ArC), $132.7\left(\mathrm{~d},{ }^{3} J_{\mathrm{CF}}=9 \mathrm{~Hz}, \mathrm{C}-2^{\prime}\right.$ and $\left.\mathrm{C}-6^{\prime}\right), 130.8,129.7,126.9(\mathrm{ArC}), 123.8\left(\mathrm{C}-1^{\prime}\right)$, $115.2\left(\mathrm{~d},{ }^{3} J_{\mathrm{CF}}=24 \mathrm{~Hz}, \mathrm{C}-3^{\prime}\right.$ and $\left.\mathrm{C}-5^{\prime}\right), 60.5\left(\mathrm{OCH}_{2} \mathrm{CH}_{3}\right), 14.1\left(\mathrm{OCH}_{2} \mathrm{CH}_{3}\right) ;$ HRMS (ESI-TOF) $m / z:[\mathrm{M}+\mathrm{H}]^{+}$Calcd. for $\mathrm{C}_{18} \mathrm{H}_{15} \mathrm{ClFN}_{2} \mathrm{O}_{2}$ 345.0801, found: 345.0810 .

Ethyl 1-(4-Chlorophenyl)-5-(3-fluorophenyl)-1H-imidazole-4-carboxylate $\mathbf{1 7 h}$

Yield: $1.19 \mathrm{~g}, 67 \%$ as a pale yellow solid; $\mathrm{mp}: 118-120{ }^{\circ} \mathrm{C} ;{ }^{1} \mathrm{H}$ NMR $\left(400 \mathrm{MHz}, \mathrm{CDCl}_{3}\right)$ $\delta 7.74(1 \mathrm{H}, \mathrm{s}, 2-\mathrm{CH}), 7.33(2 \mathrm{H}, \mathrm{d}, J=8.0 \mathrm{~Hz}, \mathrm{ArH}), 7.28-7.32(1 \mathrm{H}, \mathrm{m}, \mathrm{ArH}), 6.99-7.07(5 \mathrm{H}$, $\mathrm{m}, \mathrm{ArH}), 4.28\left(2 \mathrm{H}, \mathrm{q}, J=7.0 \mathrm{~Hz}, \mathrm{OCH}_{2} \mathrm{CH}_{3}\right), 1.28\left(3 \mathrm{H}, \mathrm{t}, J=7.0 \mathrm{~Hz}, \mathrm{OCH}_{2} \mathrm{CH}_{3}\right) ;{ }^{13} \mathrm{C} \mathrm{NMR}$ $\left(101 \mathrm{MHz}, \mathrm{CDCl}_{3}\right) \delta 162.4(\mathrm{C}=\mathrm{O}), 161.9\left(\mathrm{~d},{ }^{1} J_{\mathrm{CF}}=247 \mathrm{~Hz}, \mathrm{FC}-3^{\prime}\right), 137.5(\mathrm{C}-2), 136.3(\mathrm{~d}$, $\left.{ }^{4} J_{C F}=2 \mathrm{~Hz}, \mathrm{C}-6^{\prime}\right), 134.7,133.6,131.0,129.9,29.8(\mathrm{ArC}), 129.4\left(\mathrm{~d},{ }^{3} \mathrm{~J}_{\mathrm{CF}}=9 \mathrm{~Hz}, \mathrm{C}-5^{\prime}\right), 126.8$, $(\mathrm{ArC}), 126.4\left(\mathrm{~d},{ }^{3} J_{C F}=3 \mathrm{~Hz}, \mathrm{C}-1^{\prime}\right), 117.9\left(\mathrm{~d},{ }^{3} J_{C F}=22 \mathrm{~Hz}, \mathrm{C}-4^{\prime}\right), 116.0\left(\mathrm{~d},{ }^{3} J_{C F}=21 \mathrm{~Hz}\right.$, C-2' $), 60.5\left(\mathrm{OCH}_{2} \mathrm{CH}_{3}\right), 14.1\left(\mathrm{OCH}_{2} \mathrm{CH}_{3}\right)$; HRMS (ESI-TOF) $m / z$ : $[\mathrm{M}+\mathrm{H}]^{+}$Calcd. for $\mathrm{C}_{18} \mathrm{H}_{15} \mathrm{ClFN}_{2} \mathrm{O}_{2}$ 345.0801, found: 345.0804 .

Ethyl 1-(4-Chlorophenyl)-5-(3-methoxyphenyl)-1H-imidazole-4-carboxylate 17i

Yield: $582 \mathrm{mg}, 32 \%$ as a yellow solid; $\mathrm{mp}: 127-129{ }^{\circ} \mathrm{C} ;{ }^{1} \mathrm{H}$ NMR $\left(400 \mathrm{MHz}, \mathrm{CDCl}_{3}\right) \delta$ $7.69(1 \mathrm{H}, \mathrm{s}, 2-\mathrm{CH}), 7.28(2 \mathrm{H}, \mathrm{d}, J=9.0 \mathrm{~Hz}, \mathrm{ArH}), 7.17(1 \mathrm{H}, \mathrm{t}, J=6.0 \mathrm{~Hz}, \mathrm{ArH}), 7.01(2 \mathrm{H}, \mathrm{d}$, $J=9.0 \mathrm{~Hz}, \mathrm{ArH}), 6.77-6.87(3 \mathrm{H}, \mathrm{m}, \mathrm{ArH}), 4.25\left(2 \mathrm{H}, \mathrm{q}, J=7.2 \mathrm{~Hz}, \mathrm{OCH}_{2} \mathrm{CH}_{3}\right), 3.69(3 \mathrm{H}, \mathrm{s}$, $\left.\mathrm{ArOCH}_{3}\right), 1.25\left(3 \mathrm{H}, \mathrm{t}, J=7.0 \mathrm{~Hz}, \mathrm{OCH}_{2} \mathrm{CH}_{3}\right) ;{ }^{13} \mathrm{C} \mathrm{NMR}\left(101 \mathrm{MHz}, \mathrm{CDCl}_{3}\right) \delta 162.6(\mathrm{C}=\mathrm{O})$, $158.9\left(\mathrm{ArCOCH}_{3}\right), 137.7(\mathrm{C}-2), 137.3,134.5,134.1,130.8,129.9,129.6,129.0,126.8,123.1$, 116.5, $114.5(\mathrm{ArC}), 60.5\left(\mathrm{OCH}_{2} \mathrm{CH}_{3}\right), 55.1\left(\mathrm{ArCOCH}_{3}\right), 14.2\left(\mathrm{OCH}_{2} \mathrm{CH}_{3}\right)$; HRMS (ESI-TOF) $m / z:[\mathrm{M}+\mathrm{H}]^{+}$Calcd. for $\mathrm{C}_{19} \mathrm{H}_{18} \mathrm{ClN}_{2} \mathrm{O}_{3}$ 357.1000, found: 357.1007. 
Ethyl 1-(4-Chlorophenyl)-5-(3-methylphenyl)-1H-imidazole-4-carboxylate 17j

Yield: $713 \mathrm{mg}, 41 \%$ as a yellow solid; mp: $144-146{ }^{\circ} \mathrm{C} ;{ }^{1} \mathrm{H} \mathrm{NMR}\left(400 \mathrm{MHz}, \mathrm{CDCl}_{3}\right) \delta$ $=7.69(1 \mathrm{H}, \mathrm{s}, 2-\mathrm{CH}), 7.28(2 \mathrm{H}, \mathrm{d}, J=9.0 \mathrm{~Hz}, \mathrm{ArH}), 7.12-7.22(2 \mathrm{H}, \mathrm{m}, \mathrm{ArH}), 7.05-7.17(4 \mathrm{H}$, $\mathrm{m}, \mathrm{ArH}), 4.25\left(2 \mathrm{H}, \mathrm{q}, J=7.0 \mathrm{~Hz}, \mathrm{OCH}_{2} \mathrm{CH}_{3}\right), 2.27\left(3 \mathrm{H}, \mathrm{s}, \mathrm{ArCH}_{3}\right), 1.25(3 \mathrm{H}, \mathrm{t}, J=7.0 \mathrm{~Hz}$, $\left.\mathrm{OCH}_{2} \mathrm{CH}_{3}\right) ;{ }^{13} \mathrm{C} \mathrm{NMR}\left(101 \mathrm{MHz}, \mathrm{CDCl}_{3}\right) \delta 162.7(\mathrm{C}=\mathrm{O}), 138.2,137.6(\mathrm{C}-2), 137.2,134.5,134.2$, $131.2,130.7,129.8,129.6,127.9,127.8,127.7,126.9(\mathrm{ArC}), 60.4\left(\mathrm{OCH}_{2} \mathrm{CH}_{3}\right), 21.3\left(\mathrm{ArCCH}_{3}\right)$, 14.2 $\left(\mathrm{OCH}_{2} \mathrm{CH}_{3}\right)$; HRMS (ESI-TOF) $m / z:[\mathrm{M}+\mathrm{H}]^{+}$Calcd. for $\mathrm{C}_{19} \mathrm{H}_{18} \mathrm{ClN}_{2} \mathrm{O}_{2} 341.1051$, found: 341.1058 .

Ethyl 1-(4-Chlorophenyl)-5-(4-methylphenyl)-1H-imidazole-4-carboxylate 17k

Yield: $661 \mathrm{mg}, 38 \%$ as a pale yellow solid; mp: $161-163{ }^{\circ} \mathrm{C} ;{ }^{1} \mathrm{H}$ NMR $\left(400 \mathrm{MHz}, \mathrm{CDCl}_{3}\right)$ $\delta 7.68(1 \mathrm{H}, \mathrm{s}, 2-\mathrm{CH}), 7.28(2 \mathrm{H}, \mathrm{d}, J=9.0 \mathrm{~Hz}, \mathrm{ArH}), 7.09(4 \mathrm{H}, \mathrm{m}, \mathrm{ArH}), 6.99-7.02(2 \mathrm{H}, \mathrm{m}, \mathrm{ArH})$, $4.26\left(2 \mathrm{H}, \mathrm{q}, J=8.0 \mathrm{~Hz}, \mathrm{OCH}_{2} \mathrm{CH}_{3}\right), 2.31\left(3 \mathrm{H}, \mathrm{s}, \mathrm{ArCH}_{3}\right), 1.27\left(3 \mathrm{H}, \mathrm{t}, J=7.0 \mathrm{~Hz}, \mathrm{OCH}_{2} \mathrm{CH}_{3}\right)$; ${ }^{13} \mathrm{C}$ NMR $\left(101 \mathrm{MHz}, \mathrm{CDCl}_{3}\right) \delta 162.7(\mathrm{C}=\mathrm{O}), 138.9,138.2(\mathrm{C}-2), 137.2,134.4,134.1,130.5$, 130.2, 129.6, 128.7, 126.7, 124.7 (ArC), $60.5\left(\mathrm{OCH}_{2} \mathrm{CH}_{3}\right), 21.3\left(\mathrm{ArCCH}_{3}\right), 14.2\left(\mathrm{OCH}_{2} \mathrm{CH}_{3}\right)$; HRMS (ESI-TOF) $m / z$ : $[\mathrm{M}+\mathrm{H}]^{+}$Calcd for $\mathrm{C}_{18} \mathrm{H}_{15} \mathrm{ClFN}_{2} \mathrm{O}_{2}$ 341.1051, found: 341.1052 .

Ethyl 1-(4-Chlorophenyl)-5-phenyl-1H-imidazole-4-carboxylate 171

Yield: $534 \mathrm{mg}, 32 \%$ as a yellow solid; $\mathrm{mp}: 133-135{ }^{\circ} \mathrm{C} ;{ }^{1} \mathrm{H}$ NMR $\left(400 \mathrm{MHz}, \mathrm{CDCl}_{3}\right)$ $\delta 7.66(1 \mathrm{H}, \mathrm{s}, 2-\mathrm{CH}), 7.23-7.25(5 \mathrm{H}, \mathrm{m}, \mathrm{ArH}), 7.16(2 \mathrm{H}, \mathrm{d}, J=7.2 \mathrm{~Hz}, \mathrm{ArH}), 6.95(2 \mathrm{H}, \mathrm{d}$, $J=8.8 \mathrm{~Hz}, \mathrm{ArH}), 4.20\left(2 \mathrm{H}, \mathrm{q}, J=7.0 \mathrm{~Hz}, \mathrm{OCH}_{2} \mathrm{CH}_{3}\right), 1.20\left(3 \mathrm{H}, \mathrm{t}, J=7.0 \mathrm{~Hz}, \mathrm{OCH}_{2} \mathrm{CH}_{3}\right) ;{ }^{13} \mathrm{C}$ $\operatorname{NMR}\left(101 \mathrm{MHz}, \mathrm{CDCl}_{3}\right) \delta 162.6(\mathrm{C}=\mathrm{O}), 137.9(\mathrm{C}-2), 137.3,134.5,134.0,130.6,130.6,129.6$, $128.9,128.0,127.8,126.9(\mathrm{ArC}), 60.5\left(\mathrm{OCH}_{2} \mathrm{CH}_{3}\right), 14.2\left(\mathrm{OCH}_{2} \mathrm{CH}_{3}\right)$; HRMS (ESI-TOF) $m / z$ : $[\mathrm{M}+\mathrm{H}]^{+}$Calcd for $\mathrm{C}_{18} \mathrm{H}_{15} \mathrm{ClFN}_{2} \mathrm{O}_{2}$ 327.0895, found: 327.0898 .

3.1.5. General Synthetic Procedure for the Preparation of 1,5-Diaryl-1H-imidazole-4-carboxylic Acids 10a-1

$\mathrm{NaOH}$ (4 mmol) was added to a solution of ethyl 1,5-diaryl-1H-imidazoyl carboxylate $17(2 \mathrm{mmol})$ in $\mathrm{MeOH}(10 \mathrm{~mL})$ and $\mathrm{H}_{2} \mathrm{O}(10 \mathrm{~mL})$. The resulting reaction mixture was heated under reflux until the disappearance of the starting material (monitored by TLC). $\mathrm{MeOH}$ solvent was then removed in vacuo and the remaining aqueous crude material was slowly neutralized with $1 \mathrm{M} \mathrm{HCl}$, followed by extraction with EtOAc $(2 \times 20 \mathrm{~mL})$. The organic layer was then washed with brine, dried over $\mathrm{MgSO}_{4}$, and the solvent was removed in vacuo to produce the desired novel 1,5-diaryl- $1 \mathrm{H}$-imidazole-4-carboxylic acids $\mathbf{1 0}$.

1-(4-Bromophenyl)-5-(4-fluorophenyl)-1H-imidazole-4-carboxylic Acid 10a

Yield: $491 \mathrm{mg}, 68 \%$ as a pale yellow solid; ${ }^{1} \mathrm{H}$ NMR $\left(400 \mathrm{MHz}\right.$, DMSO- $\left.d_{6}\right) \delta 12.3(1 \mathrm{H}, \mathrm{br}$ s, $\mathrm{COOH}), 8.06(1 \mathrm{H}, \mathrm{s}, 2-\mathrm{CH}), 7.59(2 \mathrm{H}, \mathrm{d}, J=8.4 \mathrm{~Hz}, \mathrm{ArH}), 7.28(2 \mathrm{H}, \mathrm{t}, J=7.2 \mathrm{~Hz}), 7.13-7.19(4 \mathrm{H}$, $\mathrm{m}, \mathrm{ArH}),{ }^{13} \mathrm{C}$ NMR $\left(101 \mathrm{MHz}, \mathrm{DMSO}-d_{6}\right) \delta 163.7(\mathrm{C}=\mathrm{O}), 162.1\left(\mathrm{~d},{ }^{1} J_{\mathrm{CF}}=246.1 \mathrm{~Hz}, \mathrm{FC}-4^{\prime}\right)$, $138.2(\mathrm{C}-2), 136.2,134.7,(\mathrm{ArC}), 133.1\left(\mathrm{~d},{ }^{3} J_{\mathrm{CF}}=9 \mathrm{~Hz}, \mathrm{C}-2^{\prime}\right.$ and $\left.\mathrm{C}^{-} 6^{\prime}\right), 132.3,130.7,128.4$, 128.2 (ArC), $125.0\left(\mathrm{~d},{ }^{4} J_{C F}=3 \mathrm{~Hz}, \mathrm{C}-1^{\prime}\right) ; 121.7(\mathrm{ArC}), 114.8\left(\mathrm{~d},{ }^{3} J_{C F}=21 \mathrm{~Hz}, \mathrm{C}-2^{\prime}\right.$ and $\left.\mathrm{C}-5^{\prime}\right)$; HRMS (ESI-TOF) $m / z:[\mathrm{M}+\mathrm{H}]^{+}$Calcd, for $\mathrm{C}_{16} \mathrm{H}_{11}{ }^{79} \mathrm{BrFN}_{2} \mathrm{O}_{2} 360.9982$, found 360.9991 .

1-(4-Bromophenyl)-5-(3-fluorophenyl)-1H-imidazole-4-carboxylic Acid 10b

Yield: $520 \mathrm{mg}, 72 \%$ as a pale yellow solid; ${ }^{1} \mathrm{H}$ NMR $\left(400 \mathrm{MHz}, \mathrm{DMSO}-d_{6}\right) \delta 12.3(1 \mathrm{H}$, br s, $\mathrm{COOH}), 8.08(1 \mathrm{H}, \mathrm{s}, 2-\mathrm{CH}), 7.60(2 \mathrm{H}, \mathrm{d}, J=8.8 \mathrm{~Hz}, \mathrm{ArH}), 7.32(1 \mathrm{H}, \mathrm{d}, J=6.8 \mathrm{~Hz}, \mathrm{ArH})$, 7.16-7.22 $(4 \mathrm{H}, \mathrm{m}, \mathrm{ArH}), 7.01(1 \mathrm{H}, \mathrm{d}, J=7.6 \mathrm{~Hz}, \mathrm{ArH}) ;{ }^{13} \mathrm{C}$ NMR $\left(101 \mathrm{MHz}, \mathrm{DMSO}-d_{6}\right) \delta$ $163.6(\mathrm{C}=\mathrm{O}), 161.3\left(\mathrm{~d},{ }^{1} J_{\mathrm{CF}}=244 \mathrm{~Hz}, \mathrm{FC}-3^{\prime}\right), 138.4(\mathrm{C}-2), 135.8,136.3\left(\mathrm{~d},{ }^{4} J_{\mathrm{CF}}=2 \mathrm{~Hz}, \mathrm{C}-6^{\prime}\right)$, 132.3 (ArC), $130.8\left(\mathrm{~d}^{3}{ }^{3} J_{\mathrm{CF}}=9 \mathrm{~Hz}, \mathrm{C}-5^{\prime}\right), 129.7\left(\mathrm{~d},{ }^{3} J_{\mathrm{CF}}=9 \mathrm{~Hz}, \mathrm{C}-1^{\prime}\right), 128.4,127.7,127.0(\mathrm{ArC})$, $117.9\left(\mathrm{~d},{ }^{3} J_{C F}=23 \mathrm{~Hz}, \mathrm{C}-4^{\prime}\right), 115.4\left(\mathrm{~d},{ }^{3} J_{C F}=22 \mathrm{~Hz}, \mathrm{C}-2^{\prime}\right)$; HRMS (ESI-TOF) $m / z:[\mathrm{M}+\mathrm{H}]^{+}$ Calcd for $\mathrm{C}_{16} \mathrm{H}_{11}{ }^{79} \mathrm{BrFN}_{2} \mathrm{O}_{2} 360.9982$, found 360.9987 . 
1-(4-Bromophenyl)-5-(3-methoxyphenyl)-1H-imidazole-4-carboxylic Acid 10c

Yield: $582 \mathrm{mg}, 78 \%$ as a pale yellow solid; pale yellow solid; ${ }^{1} \mathrm{H}$ NMR $(400 \mathrm{MHz}$, DMSO- $\left.d_{6}\right) \delta 12.3(1 \mathrm{H}$, br s, COOH$), 8.05(1 \mathrm{H}, \mathrm{s}, 2-\mathrm{CH}), 7.59(2 \mathrm{H}, \mathrm{d}, J=8.0 \mathrm{~Hz}, \mathrm{ArH})$, $7.18(2 \mathrm{H}, \mathrm{t}, J=6.6 \mathrm{~Hz}, \mathrm{ArH}), 6.87(2 \mathrm{H}, \mathrm{d}, J=10.0 \mathrm{~Hz}, \mathrm{ArH}), 6.75(2 \mathrm{H}, \mathrm{d}, J=7.6 \mathrm{~Hz}, \mathrm{ArH})$ $3.66\left(3 \mathrm{H}, \mathrm{s}, \mathrm{ArOCH}_{3}\right) ;{ }^{13} \mathrm{C}$ NMR $\left(101 \mathrm{MHz}, \mathrm{DMSO}-d_{6}\right) \delta 163.7(\mathrm{C}=\mathrm{O}), 158.4\left(\mathrm{ArCOCH}_{3}\right)$, 138.1 (C-2), 136.9, 134.9, 132.2, 130.5, 129.8, 128.9, 128.3, 123.1, 121.6, 116.8, 144.0, (ArC), $55.0\left(\mathrm{ArCOCH}_{3}\right)$; H.RMS (ESI-TOF) $\mathrm{m} / z$ : $[\mathrm{M}+\mathrm{H}]^{+}$Calcd for $\mathrm{C}_{17} \mathrm{H}_{14}{ }^{79} \mathrm{BrN}_{2} \mathrm{O}_{3} 373.0182$, Found 373.0201.

1-(4-Bromophenyl)-5-(3-methylphenyl)-1H-imidazole-4-carboxylic Acid 10d

Yield: $536 \mathrm{mg}, 75 \%$ as a white solid; ${ }^{1} \mathrm{H}$ NMR $\left(400 \mathrm{MHz}\right.$, DMSO- $\left.d_{6}\right) \delta 12.2(1 \mathrm{H}, \mathrm{br} \mathrm{s}$, $\mathrm{COOH}), 8.04(1 \mathrm{H}, \mathrm{s}, 2-\mathrm{CH}), 7.58(2 \mathrm{H}, \mathrm{d}, J=8.4 \mathrm{~Hz}, \mathrm{ArH}), 7.10-7.19(5 \mathrm{H}, \mathrm{m}, \mathrm{ArH}), 6.97(1 \mathrm{H}$, $\mathrm{d}, J=7.2 \mathrm{~Hz}, \mathrm{ArH}), 2.22\left(3 \mathrm{H}, \mathrm{s}, \mathrm{ArCH}_{3}\right) ;{ }^{13} \mathrm{C} \mathrm{NMR}\left(101 \mathrm{MHz}, \mathrm{DMSO}-d_{6}\right) \delta 163.7(\mathrm{C}=\mathrm{O})$, 138.1 (C-2), 137.2, 136.8, 134.8, 132.2, 131.4, 130.5, 129.2, 128.5, 128.3, 127.8, 127.6, (ArC), 121.5 (ArCBr), $20.9\left(\mathrm{ArCCH}_{3}\right)$; HRMS (ESI-TOF) $m / z:[\mathrm{M}+\mathrm{H}]^{+}$Calcd for $\mathrm{C}_{17} \mathrm{H}_{14}{ }^{79} \mathrm{BrN}_{2} \mathrm{O}_{2}$ 357.0233, found 357.0244.

1-(4-Bromophenyl)-5-(4-methylphenyl)-1H-imidazole-4-carboxylic Acid 10e

Yield: $500 \mathrm{mg}, 70 \%$ as a pale yellow solid; ${ }^{1} \mathrm{H}$ NMR $\left(400 \mathrm{MHz}\right.$, DMSO- $\left.d_{6}\right) \delta 12.2(1 \mathrm{H}, \mathrm{br} \mathrm{s}$, $\mathrm{COOH}), 8.04(1 \mathrm{H}, \mathrm{s}, 2-\mathrm{CH}), 7.43(2 \mathrm{H}, \mathrm{d}, J=8.6 \mathrm{~Hz}, \mathrm{ArH}), 7.23(2 \mathrm{H}, \mathrm{d}, J=8.5 \mathrm{~Hz}, \mathrm{ArH}), 7.10(4 \mathrm{H}$, $\mathrm{m}, \mathrm{ArH}), 2.26\left(3 \mathrm{H}, \mathrm{s}, \mathrm{ArCH}_{3}\right) ;{ }^{13} \mathrm{C}$ NMR (101 MHz, DMSO- $\left.d_{6}\right) \delta 163.8(\mathrm{C}=\mathrm{O}), 138.1(\mathrm{C}-2), 137.9$, 137.3, 134.5, 133.1, 130.7, 130.4, 129.3, 128.4, 128.1, $125.6(\mathrm{ArC}), 20.9\left(\mathrm{ArCCH}_{3}\right)$; HRMS (ESITOF) $m / z:[\mathrm{M}+\mathrm{H}]^{+}$Calcd for $\mathrm{C}_{17} \mathrm{H}_{14}{ }^{79} \mathrm{BrN}_{2} \mathrm{O}_{2}$ 357.0233, found 357.0246.

1-(4-Bromophenyl)-5-phenyl-1 $H$-imidazole-4-carboxylic Acid 10f

Yield: $432 \mathrm{mg}, 63 \%$ as a white solid; ${ }^{1} \mathrm{H}$ NMR $\left(400 \mathrm{MHz}, \mathrm{DMSO}-d_{6}\right) \delta 12.2(1 \mathrm{H}, \mathrm{br}$ $\mathrm{s}, \mathrm{COOH}), 8.06(1 \mathrm{H}, \mathrm{s}, 2-\mathrm{CH}), 7.57(2 \mathrm{H}, \mathrm{d}, J=8.0 \mathrm{~Hz}, \mathrm{ArH}), 7.15-7.31(7 \mathrm{H}, \mathrm{m}, \mathrm{ArH}) ;{ }^{13} \mathrm{C}$ NMR (101 MHz, DMSO- $\left.d_{6}\right) \delta 163.7$ (C=O), 138.2 (C-2), 137.1, 134.8, 132.2, 130.8, 130.5, $128.9,128.5,128.3,127.8$ (ArC), 121.5 (ArCBr); HRMS (ESI-TOF) $m / z:[\mathrm{M}+\mathrm{H}]^{+}$Calcd for $\mathrm{C}_{16} \mathrm{H}_{12}{ }^{79} \mathrm{BrN}_{2} \mathrm{O}_{2}$ 343.0077, found 343.0089.

1-(4-Chlorophenyl)-5-(4-fluorophenyl)-1H-imidazole-4-carboxylic Acid 10g

Yield: $437 \mathrm{mg}, 69 \%$ as a pale yellow solid; ${ }^{1} \mathrm{H}$ NMR $\left(400 \mathrm{MHz}, \mathrm{DMSO}-d_{6}\right) \delta 8.10(1 \mathrm{H}$, $\mathrm{s}, 2-\mathrm{CH}), 7.46(2 \mathrm{H}, \mathrm{d}, J=8.4 \mathrm{~Hz}, \mathrm{ArH}), 7.25-7.32(4 \mathrm{H}, \mathrm{m}, \mathrm{ArH}), 7.13(2 \mathrm{H}, \mathrm{t}, J=8.7 \mathrm{~Hz}$, ArH), ${ }^{13} \mathrm{C}$ NMR $\left(101 \mathrm{MHz}, \mathrm{DMSO}-d_{6}\right) \delta 163.4(\mathrm{C}=\mathrm{O}), 162.2\left(\mathrm{~d},{ }^{1} J_{\mathrm{CF}}=246.1 \mathrm{~Hz}, \mathrm{FC}-4^{\prime}\right)$, 138.3 (C-2), 136.3, 134.1, 133,3, (ArC), $133.2\left(\mathrm{~d}^{3}{ }^{3} \mathrm{~J}_{\mathrm{CF}}=8 \mathrm{~Hz}, \mathrm{C}-2^{\prime}\right.$ and $\left.\mathrm{C}-6^{\prime}\right), 131.8,131.6,129.4$, 128.2 (ArC), $124.7\left(\mathrm{~d},{ }^{4} J_{\mathrm{CF}}=3 \mathrm{~Hz}, \mathrm{C}-1^{\prime}\right) ; 114.8\left(\mathrm{~d},{ }^{3} J_{\mathrm{CF}}=22.1 \mathrm{~Hz}, \mathrm{C}-3^{\prime}\right.$ and $\left.\mathrm{C}-5^{\prime}\right)$; HRMS (ESI-TOF) $m / z:[\mathrm{M}+\mathrm{H}]^{+}$Calcd, for $\mathrm{C}_{16} \mathrm{H}_{11} \mathrm{ClFN}_{2} \mathrm{O}_{2}$ 317.0488, found 317.0499.

1-(4-Chlorophenyl)-5-(3-fluorophenyl)-1H-imidazole-4-carboxylic Acid 10h

Yield: $443 \mathrm{mg}, 70 \%$ as a pale yellow solid; ${ }^{1} \mathrm{H}$ NMR $\left(400 \mathrm{MHz}, \mathrm{DMSO}-d_{6}\right) \delta 7.93(1 \mathrm{H}$, $\mathrm{s}, 2-\mathrm{CH}), 7.44(2 \mathrm{H}, \mathrm{d}, J=7.6 \mathrm{~Hz}, \mathrm{ArH}), 7.17-7.19(4 \mathrm{H}, \mathrm{m}, \mathrm{ArH}), 6.90-7.06(2 \mathrm{H}, \mathrm{m}, \mathrm{ArH})$, ${ }^{13} \mathrm{C}$ NMR $\left(101 \mathrm{MHz}, \mathrm{DMSO}-d_{6}\right) \delta 161.4(\mathrm{C}=\mathrm{O}), 161.2\left(\mathrm{~d},{ }^{1} J_{\mathrm{CF}}=244 \mathrm{~Hz}, \mathrm{FC}-3^{\prime}\right), 138.0(\mathrm{C}-2)$, 134.7 (ArC), $132.4\left(\mathrm{~d},{ }^{3} \mathrm{~J}_{\mathrm{CF}}=4 \mathrm{~Hz}, \mathrm{C}-6^{\prime}\right), 132.1,132.2(\mathrm{ArC}), 129.2\left(\mathrm{~d},{ }^{3} J_{\mathrm{CF}}=9 \mathrm{~Hz}, \mathrm{C}-5^{\prime}\right)$, $129.4\left(\mathrm{~d},{ }^{3} J_{\mathrm{CF}}=8 \mathrm{~Hz}, \mathrm{C}-1^{\prime}\right), 128.2,127.0,121.5(\mathrm{ArC}), 118.1\left(\mathrm{~d},{ }^{3} J_{C F}=23 \mathrm{~Hz}, \mathrm{C}-4^{\prime}\right), 115.1(\mathrm{~d}$, ${ }^{3} J_{C F}=21 \mathrm{~Hz}, \mathrm{C}-2^{\prime}$ ); HRMS (ESI-TOF) $m / z:[\mathrm{M}+\mathrm{H}]^{+}$Calcd, for $\mathrm{C}_{16} \mathrm{H}_{11} \mathrm{ClFN}_{2} \mathrm{O}_{2}$ 317.0488, found 317.0497.

1-(4-Chlorophenyl)-5-(3-methoxyphenyl)-1H-imidazole-4-carboxylic Acid 10i

Yield: $526 \mathrm{mg}, 80 \%$ as a white solid; ${ }^{1} \mathrm{H}$ NMR $\left(400 \mathrm{MHz}\right.$, DMSO- $\left.d_{6}\right) \delta 11.9(1 \mathrm{H}, \mathrm{br} \mathrm{s}$, $\mathrm{COOH}), 9.23(1 \mathrm{H}, \mathrm{s}, 2-\mathrm{CH}), 7.52(2 \mathrm{H}, \mathrm{d}, J=8.4 \mathrm{~Hz}, \mathrm{ArH}), 7.41(2 \mathrm{H}, \mathrm{d}, J=8.4 \mathrm{~Hz}, \mathrm{ArH})$, $7.22(1 \mathrm{H}, \mathrm{t}, J=8.0 \mathrm{~Hz}, \mathrm{ArH}), 6.93(2 \mathrm{H}, \mathrm{d}, J=6.2 \mathrm{~Hz}, \mathrm{ArH}), 6.84(2 \mathrm{H}, \mathrm{d}, J=6.2 \mathrm{~Hz}, \mathrm{ArH})$, $3.65\left(3 \mathrm{H}, \mathrm{s}, \mathrm{ArOCH}_{3}\right) ;{ }^{13} \mathrm{C}$ NMR $\left(101 \mathrm{MHz}, \mathrm{DMSO}-d_{6}\right) \delta 160.6(\mathrm{C}=\mathrm{O}), 158.5\left(\mathrm{ArCOCH}_{3}\right)$, 138.0 (C-2), 137.3, 134.4, 133.1, 129.4, 129.2, 128.7, 127.2, 124.7, 123.1, 117.0, 115.1 (ArC), 
55.1 $\left(\mathrm{ArCOCH}_{3}\right)$; HRMS (ESI-TOF) $m / z:[\mathrm{M}+\mathrm{H}]^{+}$Calcd, for $\mathrm{C}_{17} \mathrm{H}_{14} \mathrm{ClN}_{2} \mathrm{O}_{3}$ 329.0687, found 329.0693 .

\section{1-(4-Chlorophenyl)-5-(3-methylphenyl)-1H-imidazole-4-carboxylic Acid 10j}

Yield: $519 \mathrm{mg}, 83 \%$ as a pale yellow solid; ${ }^{1} \mathrm{H}$ NMR $\left(400 \mathrm{MHz}, \mathrm{DMSO}-d_{6}\right) \delta 8.05(1 \mathrm{H}$, $\mathrm{s}, 2-\mathrm{CH}), 7.44(2 \mathrm{H}, \mathrm{d}, J=8.7 \mathrm{~Hz}, \mathrm{ArH}), 7.23(2 \mathrm{H}, \mathrm{d}, J=8.7 \mathrm{~Hz}, \mathrm{ArH}), 7.09(3 \mathrm{H}, \mathrm{m}, \mathrm{ArH})$, $6.98(1 \mathrm{H}, \mathrm{d}, J=7.4 \mathrm{~Hz}, \mathrm{ArH}), 2.22\left(3 \mathrm{H}, \mathrm{s}, \mathrm{ArCH}_{3}\right) ;{ }^{13} \mathrm{C} \mathrm{NMR}\left(101 \mathrm{MHz}, \mathrm{DMSO}-d_{6}\right) \delta$ 163.7 (C=O), 138.1 (C-2), 137.3, 136.8, 134.4, 133.1, 131.4, 130.3, 130.4, 129.2, 128.5, 128.0, 127.9, 127.6 (ArC), $20.9\left(\mathrm{ArCCH}_{3}\right)$; HRMS (ESI-TOF) $m / z$ : [M + H] ${ }^{+}$Calcd, for $\mathrm{C}_{17} \mathrm{H}_{14} \mathrm{ClN}_{2} \mathrm{O}_{2}$ 313.0738 , found 313.0744 .

1-(4-Chlorophenyl)-5-(4-methylphenyl)-1H-imidazole-4-carboxylic Acid 10k

Yield: $494 \mathrm{mg}, 79 \%$ as a pale yellow solid; ${ }^{1} \mathrm{H}$ NMR $\left(400 \mathrm{MHz}\right.$, DMSO- $\left.d_{6}\right) \delta 12.0(1 \mathrm{H}$, br s, $\mathrm{COOH}), 9.38(1 \mathrm{H}, \mathrm{s}, 2-\mathrm{CH}), 7.51(2 \mathrm{H}, \mathrm{d}, J=8.5 \mathrm{~Hz}, \mathrm{ArH}), 7.41(2 \mathrm{H}, \mathrm{d}, J=8.5 \mathrm{~Hz}, \mathrm{ArH})$, $7.19(2 \mathrm{H}, \mathrm{d}, J=8.0 \mathrm{~Hz}, \mathrm{ArH}), 7.13(2 \mathrm{H}, \mathrm{d}, J=8.0 \mathrm{~Hz}, \mathrm{ArH}), 2.26\left(3 \mathrm{H}, \mathrm{s}, \mathrm{ArCH}_{3}\right) ;{ }^{13} \mathrm{C} \mathrm{NMR}$ $\left(101 \mathrm{MHz}, \mathrm{DMSO}-d_{6}\right) \delta 160.3(\mathrm{C}=\mathrm{O}), 139.5,138.0(\mathrm{C}-2), 137.9,134.5,133.0,131.0,129.4$, $128.8,128.7,123.9,122.7(\mathrm{ArC}), 20.9\left(\mathrm{ArCCH}_{3}\right)$; HRMS (ESI-TOF) $m / z:[\mathrm{M}+\mathrm{H}]^{+}$Calcd, for $\mathrm{C}_{17} \mathrm{H}_{14} \mathrm{ClN}_{2} \mathrm{O}_{2}$ 313.0738, found 313.0747.

1-(4-Chlorophenyl)-5-phenyl-1H-imidazole-4-carboxylic Acid 101

Yield: $460 \mathrm{mg}, 77 \%$ as a white solid; ${ }^{1} \mathrm{H}$ NMR $\left(400 \mathrm{MHz}, \mathrm{DMSO}-\mathrm{d}_{6}\right) \delta 8.75(1 \mathrm{H}$, $\mathrm{s}, 2-\mathrm{CH}), 7.46(2 \mathrm{H}, \mathrm{d}, J=10 \mathrm{~Hz}, \mathrm{ArH}), 7.26-7.36(7 \mathrm{H}, \mathrm{m}, \mathrm{ArH}) ;{ }^{13} \mathrm{C} \mathrm{NMR}(101 \mathrm{MHz}$, DMSO- $\left.d_{6}\right) \delta 162.1(\mathrm{C}=\mathrm{O}), 138.3(\mathrm{C}-2), 137.9,134.4,133.7,131.2,129.7,128.7,128.4,128.3$, 127.1, 126.9 (ArC); HRMS (ESI-TOF) $m / z$ : $[\mathrm{M}+\mathrm{H}]^{+}$Calcd, for $\mathrm{C}_{16} \mathrm{H}_{12} \mathrm{ClN}_{2} \mathrm{O}_{2}$ 299.0582, found 299.0587 .

3.1.6. General Procedure for the Synthesis of 1,5-diaryl- $1 \mathrm{H}$-imidazole-4-carbohydrazide Derivatives 11a-b, 11d-e, 11g-1

Ethyl 1,5-diaryl- $1 \mathrm{H}$-imidazole-4-carboxylate derivative 17 (2.55 $\mathrm{mmol})$ was placed in a $25 \mathrm{~mL}$ carousel vessel followed by the addition of ethanol $(15 \mathrm{~mL})$ and hydrazine hydrate monohydrate $(33.2 \mathrm{mmol})$. The resulting reaction mixture was heated at reflux using a Carousel 12 Plus Reaction Station ${ }^{\mathrm{TM}}$ set at $100{ }^{\circ} \mathrm{C}$ with stirring. After $24 \mathrm{~h}$, the solution was allowed to cool to room temperature to form a precipitated solid which was collected by filtration and washed with a small amount of cooled ethyl alcohol and dried under vacuum to afford 1,5-diaryl-1H-imidazole-4- carbohydrazide derivative $\mathbf{1 1}$.

1-(4-Bromophenyl)-5-(4-fluorophenyl)-1H-imidazole-4-carbohydrazide 11a

Yield: $727 \mathrm{mg}, 76 \%$ as a white solid; ${ }^{1} \mathrm{H}$ NMR $\left(400 \mathrm{MHz}, \mathrm{DMSO}-d_{6}\right) \delta 9.24(1 \mathrm{H}, \mathrm{br}$ s, NH), $8.06(1 \mathrm{H}, \mathrm{s}, 2-\mathrm{CH}), 7.63(2 \mathrm{H}, \mathrm{d}, J=8.8 \mathrm{~Hz}, \mathrm{ArH}), 7.26(2 \mathrm{H}, \mathrm{t}, J=8.7 \mathrm{~Hz}, \mathrm{ArH})$. 7.10-7.19 $(4 \mathrm{H}, \mathrm{m}, \mathrm{ArH}), 4.42\left(1 \mathrm{H}, \mathrm{br} \mathrm{s}, \mathrm{NH}_{2}\right) ;{ }^{13} \mathrm{C} \mathrm{NMR}\left(101 \mathrm{MHz}, \mathrm{DMSO}-d_{6}\right) \delta 161.4(\mathrm{C}=\mathrm{O})$, $161.9\left(\mathrm{~d},{ }^{1} J_{C F}=244 \mathrm{~Hz}, \mathrm{FC}-3^{\prime}\right), 137.7(\mathrm{C}-2), 134.8,133.2(\mathrm{ArC}), 133.2\left(\mathrm{~d},{ }^{3} J_{C F}=9 \mathrm{~Hz}, \mathrm{C}-2^{\prime}\right.$ and $\left.\mathrm{C}-6^{\prime}\right), 132.6,132.3,132.0,128.2(\mathrm{ArC}), 124.7\left(\mathrm{~d},{ }^{4} J_{C F}=3 \mathrm{~Hz}, \mathrm{C}-1^{\prime}\right) ; 121.5(\operatorname{ArC}), 114.5(\mathrm{~d}$, $\left.{ }^{3} J_{C F}=22 \mathrm{~Hz}, \mathrm{C}-4^{\prime}\right)$; HRMS (ESI-TOF) $m / z:[\mathrm{M}+\mathrm{H}]^{+}$Calcd for $\mathrm{C}_{16} \mathrm{H}_{13} \mathrm{~F}^{79} \mathrm{BrN}_{4} \mathrm{O} 375.0251$, measured 375.0255.

1-(4-Bromophenyl)-5-(3-fluorophenyl)-1H-imidazole-4-carbohydrazide $\mathbf{1 1 b}$

Yield: $698 \mathrm{mg}, 73 \%$ as a white solid; ${ }^{1} \mathrm{H}$ NMR $\left(400 \mathrm{MHz}, \mathrm{DMSO}-d_{6}\right) \delta 9.25(1 \mathrm{H}, \mathrm{br}$ $\mathrm{s}, \mathrm{NH}), 8.08(1 \mathrm{H}, \mathrm{s}, 2-\mathrm{CH}), 7.61(2 \mathrm{H}, \mathrm{d}, J=7.6 \mathrm{~Hz}, \mathrm{ArH}), 7.27(2 \mathrm{H}, \mathrm{d}, J=8.0 \mathrm{~Hz}, \mathrm{ArH})$, 7.12-7.22 $(4 \mathrm{H}, \mathrm{m}, \mathrm{ArH}), 6.96(2 \mathrm{H}, \mathrm{d}, J=8.0 \mathrm{~Hz}, \mathrm{ArH}), 4.42\left(1 \mathrm{H}, \mathrm{br} \mathrm{s}, \mathrm{NH}_{2}\right) ;{ }^{13} \mathrm{C} \mathrm{NMR}$ $\left(101 \mathrm{MHz}, \mathrm{DMSO}-d_{6}\right) \delta 161.4(\mathrm{C}=\mathrm{O}), 161.2\left(\mathrm{~d},{ }^{1} J_{C F}=244 \mathrm{~Hz}, \mathrm{FC}-3^{\prime}\right), 137.9(\mathrm{C}-2), 134.7,132.4$, $133.2\left(\mathrm{~d},{ }^{4} \mathrm{~J}_{\mathrm{CF}}=3 \mathrm{~Hz}, \mathrm{C}-6^{\prime}\right), 132.1(\mathrm{ArC}), 130.6\left(\mathrm{~d},{ }^{3} J_{\mathrm{CF}}=9 \mathrm{~Hz}, \mathrm{C}-1^{\prime}\right), 129.4\left(\mathrm{~d},{ }^{3} J_{\mathrm{CF}}=8 \mathrm{~Hz}\right.$, C-5') $128.2,126.9,121.5(\mathrm{ArC}), 118.1\left(\mathrm{~d},{ }^{3} J_{\mathrm{CF}}=23 \mathrm{~Hz}, \mathrm{C}-2^{\prime}\right), 115.1\left(\mathrm{~d},{ }^{3} J_{\mathrm{CF}}=21 \mathrm{~Hz}, \mathrm{C}-4^{\prime}\right)$; HRMS (ESI-TOF) $m / z$ : $[\mathrm{M}+\mathrm{H}]^{+}$Calcd for $\mathrm{C}_{16} \mathrm{H}_{13} \mathrm{~F}^{79} \mathrm{BrN}_{4} \mathrm{O}$ 375.0251, measured 375.0250. 
1-(4-Bromophenyl)-5-(3-methylphenyl)-1H-imidazole-4-carbohydrazide 11d

Yield: $644 \mathrm{mg}, 68 \%$ as a white solid; ${ }^{1} \mathrm{H}$ NMR $\left(400 \mathrm{MHz}\right.$, DMSO- $\left.d_{6}\right) \delta 9.20(1 \mathrm{H}, \mathrm{br} \mathrm{s}$, $\mathrm{NH}), 8.07(1 \mathrm{H}, \mathrm{s}, 2-\mathrm{CH}), 7.62(2 \mathrm{H}, \mathrm{d}, J=8.8 \mathrm{~Hz}, \mathrm{ArH}), 7.16-7.20(5 \mathrm{H}, \mathrm{m}, \mathrm{ArH}), 6.96(1 \mathrm{H}$, $\mathrm{d}, J=4.4 \mathrm{~Hz}, \mathrm{ArH}), 4.42\left(2 \mathrm{H}, \mathrm{br} \mathrm{s}, \mathrm{NH}_{2}\right), 2.26\left(3 \mathrm{H}, \mathrm{s}, \mathrm{ArCH}_{3}\right) ;{ }^{13} \mathrm{C} \mathrm{NMR}(101 \mathrm{MHz}$, DMSO- $\left.d_{6}\right) \delta 161.6(\mathrm{C}=\mathrm{O}), 137.6(\mathrm{C}-2), 136.6,135.0,133.6,132.2,131.9,131.6,128.9,128.2$, 128.1, 127.8, 127.5, $121.3(\mathrm{ArC}), 21.0\left(\mathrm{ArCCH}_{3}\right)$; HRMS (ESI-TOF) $m / z:[\mathrm{M}+\mathrm{H}]^{+}$Calcd for $\mathrm{C}_{17} \mathrm{H}_{16}{ }^{79} \mathrm{BrN}_{4} \mathrm{O} 371.0502$, measured 371.0499 .

1-(4-Bromophenyl)-5-(4-methylphenyl)-1H-imidazole-4-carbohydrazide 11e

Yield: $606 \mathrm{mg}, 64 \%$ as a white solid; ${ }^{1} \mathrm{H}$ NMR $\left(400 \mathrm{MHz}, \mathrm{DMSO}-d_{6}\right) \delta 9.16(1 \mathrm{H}, \mathrm{br}$ $\mathrm{s}, \mathrm{NH}), 8.05(1 \mathrm{H}, \mathrm{s}, 2-\mathrm{CH}), 7.49(2 \mathrm{H}, \mathrm{d}, J=8.5 \mathrm{~Hz}, \mathrm{ArH}), 7.24(2 \mathrm{H}, \mathrm{d}, J=8.5 \mathrm{~Hz}, \mathrm{ArH})$, 7.09-7.15 (4H, m, ArH), $4.34\left(2 \mathrm{H}, \mathrm{s}, \mathrm{NH}_{2}\right), 2.29\left(3 \mathrm{H}, \mathrm{s}, \mathrm{ArCH}_{3}\right) ;{ }^{13} \mathrm{C}$ NMR (101 MHz, DMSO$\left.d_{6}\right) \delta 161.7(\mathrm{C}=\mathrm{O}), 137.6(\mathrm{C}-2), 137.6,134.6,133.6,132.9,131.8,130.8,129.3,128.2,127.9$, 125.3 (ArC), $20.8\left(\mathrm{ArCCH}_{3}\right)$; HRMS (ESI-TOF) $\mathrm{m} / z$ : $[\mathrm{M}+\mathrm{H}]^{+}$Calcd for $\mathrm{C}_{17} \mathrm{H}_{16}{ }^{79} \mathrm{BrN}_{4} \mathrm{O}$ 371.0502, measured 371.0504.

1-(4-Chlorophenyl)-5-(4-fluorophenyl)-1H-imidazole-4-carbohydrazide 11g

Yield: $557 \mathrm{mg}, 66 \%$ as a white solid; ${ }^{1} \mathrm{H}$ NMR $\left(400 \mathrm{MHz}, \mathrm{DMSO}-d_{6}\right) \delta 9.23(1 \mathrm{H}, \mathrm{br} \mathrm{s}$, $\mathrm{NH}), 8.06(1 \mathrm{H}, \mathrm{s}, 2-\mathrm{CH}), 7.47(2 \mathrm{H}, \mathrm{d}, J=8.8 \mathrm{~Hz}, \mathrm{ArH}), 7.23-7.31(4 \mathrm{H}, \mathrm{m}, \mathrm{ArH}), 7.11(2 \mathrm{H}$, $\mathrm{t}, J=8.7 \mathrm{~Hz}, \mathrm{ArH}), 4.37\left(1 \mathrm{H}, \mathrm{br} \mathrm{s}, \mathrm{NH}_{2}\right) ;{ }^{13} \mathrm{C}$ NMR $\left(101 \mathrm{MHz}, \mathrm{DMSO}-d_{6}\right) \delta 163.1(\mathrm{C}=\mathrm{O})$, $160.1\left(\mathrm{~d},{ }^{1} \mathrm{~J}_{\mathrm{CF}}=246 \mathrm{~Hz}, \mathrm{FC}-4^{\prime}\right), 137.7(\mathrm{C}-2), 134.3(\mathrm{ArC}), 133.2\left(\mathrm{~d},{ }^{3} \mathrm{~J}_{\mathrm{CF}}=8 \mathrm{~Hz}, \mathrm{C}-2^{\prime}\right.$ and C-6' $), 133.0,129.4,132.6,132.0,129.4,128.0(\mathrm{ArC}), 124.7\left(\mathrm{~d},{ }^{4} J_{C F}=4 \mathrm{~Hz}, \mathrm{C}-1^{\prime}\right) ; 114.5(\mathrm{~d}$, ${ }^{3} J_{C F}=21 \mathrm{~Hz}, \mathrm{C}-3^{\prime}$ and $\mathrm{C}-5^{\prime}$ ); HRMS (ESI-TOF) $m / z:[\mathrm{M}+\mathrm{H}]^{+}$Calcd for $\mathrm{C}_{16} \mathrm{H}_{13} \mathrm{FClN}_{4} \mathrm{O}$ 331.0756, measured 331.0850.

1-(4-Chlorophenyl)-5-(3-fluorophenyl)-1H-imidazole-4-carbohydrazide $\mathbf{1 1 h}$

Yield: $615 \mathrm{mg}, 73 \%$ as a white solid; ${ }^{1} \mathrm{H}$ NMR $\left(400 \mathrm{MHz}, \mathrm{DMSO}-d_{6}\right) \delta 9.26(1 \mathrm{H}, \mathrm{br} \mathrm{s}$, $\mathrm{NH}), 8.08(1 \mathrm{H}, \mathrm{s}, 2-\mathrm{CH}), 7.48(2 \mathrm{H}, \mathrm{d}, J=8 \mathrm{~Hz}, \mathrm{ArH}), 7.26(3 \mathrm{H}, \mathrm{t}, J=8 \mathrm{~Hz}, \mathrm{ArH}), 7.15(2 \mathrm{H}, \mathrm{dd}$, $J=8 \mathrm{~Hz}, \mathrm{ArH}), 6.95(1 \mathrm{H}, \mathrm{d}, J=8 \mathrm{~Hz}, \mathrm{ArH}), 4.37\left(1 \mathrm{H}, \mathrm{br} \mathrm{s}, \mathrm{NH}_{2}\right) ;{ }^{13} \mathrm{C}$ NMR $(101 \mathrm{MHz}, \mathrm{DMSO}-$ $\left.d_{6}\right) \delta 162.1(\mathrm{C}=\mathrm{O}), 161.9\left(\mathrm{~d},{ }^{1} J_{C F}=244 \mathrm{~Hz}, \mathrm{FC}-3^{\prime}\right), 138.72(\mathrm{C}-2), 134.3,134.1,133.0,132.2(\mathrm{~d}$, $\left.{ }^{4} J_{C F}=3 \mathrm{~Hz}, \mathrm{C}-6^{\prime}\right), 130.6\left(\mathrm{~d},{ }^{3} J_{C F}=8 \mathrm{~Hz}, \mathrm{C}-1^{\prime}\right), 129.3\left(\mathrm{~d},{ }^{3} \mathrm{~J}_{\mathrm{CF}}=8 \mathrm{~Hz}, \mathrm{C}-5^{\prime}\right), 128.2,128.0$, 127.0 (ArC), $118.1\left(\mathrm{~d},{ }^{3} J_{C F}=22 \mathrm{~Hz}, \mathrm{C}-2^{\prime}\right), 115.5\left(\mathrm{~d},{ }^{3} J_{C F}=20 \mathrm{~Hz}, \mathrm{C}-4^{\prime}\right)$; HRMS (ESI-TOF) $m / z:[\mathrm{M}+\mathrm{H}]^{+}$Calcd for $\mathrm{C}_{16} \mathrm{H}_{13} \mathrm{FClN}_{4} \mathrm{O}$ 331.0756, measured 331.0767.

1-(4-Chlorophenyl)-5-(3-methoxyphenyl)-1H-imidazole-4-carbohydrazide 11i

Yield: $594 \mathrm{mg}, 68 \%$ as a white solid; ${ }^{1} \mathrm{H}$ NMR $\left(400 \mathrm{MHz}\right.$, DMSO- $\left.d_{6}\right) \delta 9.19(1 \mathrm{H}, \mathrm{br}$ $\mathrm{s}, \mathrm{NH}), 8.05(1 \mathrm{H}, \mathrm{s}, 2-\mathrm{CH}), 7.48(2 \mathrm{H}, \mathrm{d}, J=2.0 \mathrm{~Hz}, \mathrm{ArH}), 7.46(2 \mathrm{H}, \mathrm{d}, J=2.0 \mathrm{~Hz}, \mathrm{ArH})$, 7.15-6.90 (4H, m, ArH), $4.34\left(2 \mathrm{H}, \mathrm{br} \mathrm{s}, \mathrm{NH}_{2}\right), 3.66\left(3 \mathrm{H}, \mathrm{s}, \mathrm{ArOCH}_{3}\right) ;{ }^{13} \mathrm{C} \mathrm{NMR}(101 \mathrm{MHz}$, DMSO- $\left.d_{6}\right) \delta 161.6(\mathrm{C}=\mathrm{O}), 158.3\left(\mathrm{ArCOCH}_{3}\right), 137.7(\mathrm{C}-2), 134.6,133.3,132.9,132.0,129.5$, 129.3, 128.6, 127.9, 123.1, 116.9, $113.8(\mathrm{ArC}), 54.9\left(\mathrm{ArCOCH}_{3}\right)$; HRMS (ESI-TOF) $m / z$ : $[\mathrm{M}+\mathrm{H}]^{+}$Calcd for $\mathrm{C}_{17} \mathrm{H}_{16} \mathrm{ClN}_{4} \mathrm{O}_{2}$ 343.0956, measured 343.0957.

1-(4-Chlorophenyl)-5-(3-methylphenyl)-1H-imidazole-4-carbohydrazide 11j

Yield: $517 \mathrm{mg}, 62 \%$ as a white solid; ${ }^{1} \mathrm{H}$ NMR $\left(400 \mathrm{MHz}, \mathrm{DMSO}-d_{6}\right) \delta 9.18(1 \mathrm{H}, \mathrm{br} \mathrm{s}$, $\mathrm{NH}), 8.06(1 \mathrm{H}, \mathrm{s}, 2-\mathrm{CH}), 7.47(2 \mathrm{H}, \mathrm{d}, J=8.8 \mathrm{~Hz}, \mathrm{ArH}), 7.23(2 \mathrm{H}, \mathrm{d}, J=8.8 \mathrm{~Hz}, \mathrm{ArH}), 7.16(3 \mathrm{H}$, $\mathrm{m}, \mathrm{ArH}), 7.13(1 \mathrm{H}, \mathrm{d}, J=4.4 \mathrm{~Hz}, \mathrm{ArH}), 4.47\left(2 \mathrm{H}, \mathrm{br} \mathrm{s}, \mathrm{NH}_{2}\right), 2.24\left(3 \mathrm{H}, \mathrm{s}, \mathrm{ArCH}_{3}\right) ;{ }^{13} \mathrm{C} \mathrm{NMR}$ $\left(101 \mathrm{MHz}, \mathrm{DMSO}-d_{6}\right) \delta 161.6(\mathrm{C}=\mathrm{O}), 137.6$ (C-2), 136.6, 134.6, 133.7, 132.9, 132.0, 131.9, 131.7, 129.3, 128.9, 128.3, 127.9, $127.5(\mathrm{ArC}), 21.0\left(\mathrm{ArCCH}_{3}\right)$. HRMS (ESI-TOF) $m / z:[\mathrm{M}+\mathrm{H}]^{+}$ Calcd for $\mathrm{C}_{17} \mathrm{H}_{16} \mathrm{ClN}_{4} \mathrm{O}$ 327.1007, measured 327.1013.

1-(4-Chlorophenyl)-5-(4-methylphenyl)-1 $\mathrm{H}$-imidazole-4-carbohydrazide 11k

Yield: $528 \mathrm{mg}, 63 \%$ as a white solid; ${ }^{1} \mathrm{H}$ NMR $\left(400 \mathrm{MHz}, \mathrm{DMSO}-d_{6}\right): \delta=9.13(1 \mathrm{H}$, br s, NH), $8.02(1 \mathrm{H}, \mathrm{s}, 2-\mathrm{CH}), 7.46(2 \mathrm{H}, \mathrm{d}, J=8.8 \mathrm{~Hz}, \mathrm{ArH}), 7.21(2 \mathrm{H}, \mathrm{d}, J=8.4 \mathrm{~Hz}, \mathrm{ArH})$, 7.07-7.13 (4H, m, ArH), $4.31\left(2 \mathrm{H}, \mathrm{br} \mathrm{s}, \mathrm{NH}_{2}\right), 2.28\left(3 \mathrm{H}, \mathrm{s}, \mathrm{ArCH}_{3}\right) ;{ }^{13} \mathrm{C} \mathrm{NMR}(101 \mathrm{MHz}$, 
DMSO- $\left.d_{6}\right) \delta 161.7(\mathrm{C}=\mathrm{O}), 137.6(\mathrm{C}-2), 137.5,134.6,133.6,132.9,131.8,130.8,129.3,128.2$, $127.9,125.3$ (ArC), $20.8\left(\mathrm{ArCCH}_{3}\right)$; HRMS (ESI-TOF) $m / z:[\mathrm{M}+\mathrm{H}]^{+}$Calcd for $\mathrm{C}_{17} \mathrm{H}_{16} \mathrm{ClN}_{4} \mathrm{O}$ 327.1007, measured 327.1011.

1-(4-Chlorophenyl)-5-phenyl-1H-imidazole-4-carbohydrazide 111

Yield: $463 \mathrm{mg}, 58 \%$ as a white solid; ${ }^{1} \mathrm{H}$ NMR (400 MHz, DMSO- $\left.d_{6}\right) \delta 9.18(1 \mathrm{H}$, br s, $\mathrm{NH}), 8.06(1 \mathrm{H}, \mathrm{s}, 2-\mathrm{CH}), 7.45(2 \mathrm{H}, \mathrm{d}, J=8.8 \mathrm{~Hz}, \mathrm{ArH}), 7.22-7.30(7 \mathrm{H}, \mathrm{m}, \mathrm{ArH}), 4.33(2 \mathrm{H}$, br s, $\left.\mathrm{NH}_{2}\right) ;{ }^{13} \mathrm{C}$ NMR (101 MHz, DMSO- $\left.d_{6}\right) \delta 161.6(\mathrm{C}=\mathrm{O}), 137.7(\mathrm{C}-2), 134.5,133.5,132.9$, 132.0, 130.9, 129.3, 128.3, 128.2, 127.9, 127.6 (ArC). HRMS (ESI-TOF) $m / z:[\mathrm{M}+\mathrm{H}]^{+}$Calcd for $\mathrm{C}_{16} \mathrm{H}_{14} \mathrm{ClN}_{4} \mathrm{O} 313.0851$, measured 313.0841.

\subsection{Modeling Protocols}

The X-ray crystal structure of HIV-1 IN dimer (PDB code: 4NYF) in complex with the small molecule, BI 224436 (2) was used for a better understanding of binding interactions of the tested ligands [27]. The HIV-1 IN protein used in the modeling was prepared using the "Protein Preparation Wizard" in Maestro (Schrodinger suite, Schrödinger, Inc, Cambridge, MA, USA) [66]. This protocol involves the addition of hydrogen atoms, bond order assignment, and optimization of bond lengths, bond angles, torsion angles, and non-bonded interactions using the OPLS force field. Furthermore, missing loops and side chains were filled in using Prime with a length of axes set to $30 \AA$ and a value of the scaling factor chosen to be 1.00. Docking grids were produced with the default settings in Glide utilizing the co-crystalized ligand, BI-224436 binding site to express the focus of the grid box. Before docking, structures were minimized to their lowest energy and all possible 3D structure of molecules were created utilizing Ligprep protocol in Maestro [67]. The protocol encompasses the addition of hydrogen, transforming 2D structures to 3D, creating stereoisomers, neutralizing charges, and forecasting the probable ionization state using an OPLS3 force field. The scaffolds were then primarily positioned to the LEDGF/p75 binding site in HIV-1 integrase using the Schrödinger Glide protocol with the standard precision (SP) mode, which resulted in the generation of hundreds for poses of each compound [68].

\subsection{Biological Evaluation Protocols}

\subsubsection{HIV-1 IN-LEDGF/p75 AlphaScreen ${ }^{\mathrm{TM}}$ Assay}

An AlphaScreen ${ }^{\mathrm{TM}}$ assay was developed and used to determine the percentage inhibition of the newly synthesized 1,5-diaryl- $1 H$-imidazole-4-carboxylic acids 10 and 1,5diaryl- $1 H$-imidazole-4-carbohydrazide derivatives 11. Assay buffer (50 mM Tris pH 7.4, $1 \mathrm{mM} \mathrm{MgCl} 2,1 \mathrm{mM}$ DTT, $0.01 \%$ Tween 20, and 2.5\% Glycerol) was used to make $10 \times$ working stocks of FLAG-IN, His-LEDGF/p75 and test compounds with concentrations of $1 \mu \mathrm{M}, 5 \mu \mathrm{M}$, and $1 \mathrm{mM}$, respectively. Total reaction volumes were $50 \mu \mathrm{L}$. First, $35 \mu \mathrm{L}$ of assay buffer was added to wells of a $1 / 2$ area optiplate. Then, $5 \mu \mathrm{L}$ of a working stock of FLAG-tagged IN was added to each well containing assay buffer, except for control wells. Then, $5 \mu \mathrm{L}$ of test compounds were added to each well containing FLAG-IN and assay buffer, except for control wells. Plates were incubated for $30 \mathrm{~min}$ at room temperature with gentle shaking. Subsequently, $5 \mu \mathrm{L}$ of His-tagged LEDGF/p75 was added to each test well, except to control wells, and incubated for $1 \mathrm{~h}$ at $30{ }^{\circ} \mathrm{C}$ with gentle shaking. A final concentration of $10 \mu \mathrm{g} / \mathrm{mL}$ nickel chelating acceptor beads (Perkin Elmer, MA, USA) and Anti-FLAG donor beads (Perkin Elmer, MA, USA) were added and incubated in the dark at $30{ }^{\circ} \mathrm{C}$ with gentle shaking. The plate was subsequently read between $520-620 \mathrm{~nm}$ on the EnSpire $^{\circledR}$ plate reader (Perkin Elmer, MA, USA). The control (3) ran on the plate to ensure accurate reading of the compounds effects were: beads alone, FLAG-IN plus beads alone, His-LEDGF/p75 plus beads alone, FLAG-IN, and His-LEDGF/p75 alone. 


\subsubsection{Strand Transfer Assay}

Reaction buffer (50 mM HEPES pH 7.5, $10 \mathrm{mM} \mathrm{NaCl}, 5 \mathrm{mM} \mathrm{MnCl} 2 / \mathrm{MgCl}_{2}, 15 \mathrm{mM}$ DTT) was added to wells of a round bottom 96 well plate at $10 \mu \mathrm{L}$ per well. IN and donor DNA were mixed in reaction buffer and $10 \mu \mathrm{L}$ each was added to the wells containing pre-aliquoted reaction buffer. The final concentrations of IN and donor DNA was $200 \mathrm{nM}$ and $100 \mathrm{nM}$, respectively, in the context of the total reaction volume. The IN was allowed to complex the DNA for $15 \mathrm{~min}$. Tested compounds were added at $10 \mu \mathrm{L}$, to a final of $100 \mu \mathrm{M}$, and mixed in wells containing pre-aliquoted reaction buffer. This was incubated at ambient temperature for $15 \mathrm{~min}$. Target DNA was added in a $10 \mu \mathrm{L}$ volume to a $200 \mathrm{nM}$ final concentration. Total reaction volume was $50 \mu \mathrm{L}$. The reaction was immediately incubated at $37^{\circ} \mathrm{C}$ for $90 \mathrm{~min}$ in a shaking plate incubator. Reactions were stopped by addition of $50 \mu \mathrm{L}$ ELISA Binding buffer ( $50 \mathrm{mM}$ Tris- $\mathrm{HCl} \mathrm{pH}$ 7.5, 4M NaCl, $20 \mathrm{mM}$ EDTA), and immediately added to Streptavidin coated plates (RD Biosystems) and incubated at ambient temperature for $30 \mathrm{~min}$. Non-bound reaction products were removed by washing the wells with TBS-T ( $25 \mathrm{mM}$ Tris- $\mathrm{HCl} \mathrm{pH} 7.5,150 \mathrm{mM} \mathrm{NaCl}$, Tween $0.005 \%$ ) two times with no incubations between washes. Anti FITC-AP linked antibody (Sigma-Aldrich) was added at $200 \mu \mathrm{L}$ at a 1:5000 dilution in TBS-T and incubated at $37^{\circ} \mathrm{C}$ for $120 \mathrm{~min}$. The wells were then washed three times with TBS-T with 5 min incubation per wash. SIGMAFASTTM p-Nitrophenyl phosphate Tablets (Sigma-Aldrich), a phosphatase substrate, was prepared and added to each test well at $100 \mu \mathrm{L}$ and incubated at $37^{\circ} \mathrm{C}$ for $30 \mathrm{~min}$. Absorbance readings were determined at $405 \mathrm{~nm}$ on the X-mark spectrophotometer (Bio-Rad, Rosebank, South Africa) [59].

\subsubsection{Cellular Toxicity Assay}

The day of cytotoxicity testing, MT-4 cells (obtained through the NIH AIDS Reagent Program, Division of AIDS, NIAID, NIH: MT-4 catalogue number 120) were counted and seeded at $5 \times 10^{4}$ cells per well. A total of $100 \mu \mathrm{L}$ of cells were added to each well of a 96-well cell culture plates (TTP) for testing. The volume in the last row of wells of each plate was further increased to $197 \mu \mathrm{L}$ of media containing MT-4 cells. The plate was placed into the incubator to equilibrate to $37^{\circ} \mathrm{C}$ and $5 \% \mathrm{CO}_{2}$. Test compounds were prepared in plate format and each compound was at $25 \mathrm{mM}$ stock concentration in DMSO. A total of $3.2 \mu \mathrm{L}$ compound was added to the final row of wells containing $197 \mu \mathrm{L}$ cells and mixed to ensure the solution was homogeneous with the cells. A 2-fold serial dilution of an 8 times series was performed and the final $100 \mu \mathrm{L}$ was discarded. The plate was placed at $37^{\circ} \mathrm{C}$ and $5 \% \mathrm{CO}_{2}$ for 5 days. On the 5th day the cell viability was assessed using the Cell Titre $96^{\circledR}$ Aqueous One Solution Cell Proliferation assay (Promega) as per manufacturer's instructions. Briefly, $20 \mu \mathrm{L}$ of MTS solution was added to each well and incubated at $37^{\circ} \mathrm{C}$ for $4 \mathrm{~h}$. The absorbance of the plates was then read at $490 \mathrm{~nm}$ on a SpectraMax spectrophotometer (Molecular Devices, LLC. San Jose, CA, USA). The data analysis was completed on Origin 8.1 with the log value of the compound molar concentration plotted against the percentage cell viability determined by the absorbance level by sigmoidal fitting. From the curve, a half maximal cytotoxicity $\mathrm{CC}_{50}$ for compounds was determined. Auranofin was used as a cytotoxic control compound starting at $100 \mu \mathrm{M}$ across a two-fold serial dilution of an 8 dilution series. DMSO was used as background control and 2-fold serially diluted from $1.5 \%$ [60].

\subsubsection{Antiviral Assay}

A subtype $\mathrm{C}$ virus isolate was obtained through the NIH HIV Reagent Program, Division of AIDS, NIAID, NIH: Human Immunodeficiency Virus Type 1 strain 98/IN/022, ARP-4167, contributed by UNAIDS Network for HIV Isolation and Characterization. MT-4 cells were grown and maintained in RPMI (Gibco) supplemented with $2 \mathrm{mM}$ L-glutamine, non-essential amino acids and $10 \%$ heat inactivated fetal bovine serum at $37^{\circ} \mathrm{C}$ and $5 \%$ $\mathrm{CO}_{2}$. Subtype $\mathrm{C}$ virus was added to MT4 cells and incubated at $37^{\circ} \mathrm{C}$ and $5 \% \mathrm{CO}_{2}$ for two weeks. Supernatants were harvested by centrifugation at $4000 \times g$ and stored at $-80^{\circ} \mathrm{C}$ 
until use. Harvested supernatant containing HIV-1 was added to fresh MT-4 cells and viral absorption was allowed for $24 \mathrm{~h}$ similar to the method by Rosenwirth et al. [69]. After viral absorption, the cells were washed once with fresh media, a sample was taken, and HIV-1 infection was allowed to develop. Seven days after infection, MT-4 supernatant samples were tested for the presence of p24 antigen using the bioelisa HIV-1+2 Ag/ Ab kit (biokit) as per manufacturer's instructions. After HIV-1 infection was confirmed, supernatant samples were isolated by centrifugation at $4000 \times g$ and immediately used to infect $1 \times 10^{5}$ cells $/ \mathrm{mL}$ of MT4 cells. Virus was allowed to absorb and $24 \mathrm{~h}$ later the cells were washed with fresh media and $100 \mu \mathrm{L}$ of cells, $1 \times 10^{4}$ cells, were aliquoted into a round bottom 96 well plate (TPP). Uninfected cells were also prepared. A day 1 sample was taken and stored at $-80{ }^{\circ} \mathrm{C}$ until final testing. Compounds were diluted in fresh media to $200 \mu \mathrm{M}$ concentrations and $100 \mu \mathrm{L}$ was added to each test well, the final concentration of compounds was 100 $\mu \mathrm{M}$. Raltegravir (NIH, ARP-11680) was used as a control compound at $10 \mu \mathrm{M}$, blank wells contained equal volumes of DMSO. Upper and lower asymptotes were determined by untreated MT4 cells either infected with HIV (100\%) or not infected with HIV $(0 \%)$. Four days after infection, p24 presence was determined using the bioelisa HIV-1+2 Ag/ Ab kit as per manufacturer's instructions. The data was used to determine if the selected concentration of compounds would reduce the amount of p24 and thereby indicate a reduction in HIV infectivity [62].

\subsubsection{Multimerization}

Crosslinking reactions were prepared in Oligomerization Buffer [50 mM HEPES, pH $7.1,300 \mathrm{mM} \mathrm{NaCl}, 2 \mathrm{mM} \mathrm{MgCl} 2,1 \mathrm{mM}$ DTT] with varying concentrations of compounds and IN protein. Tested compounds were used at a range of $50 \mu \mathrm{M}, 100 \mu \mathrm{M}$, and $200 \mu \mathrm{M}$. Mut-101 was included as a control and used at $50 \mu \mathrm{M}$ only. IN enzymes were incubated with compounds for $30 \mathrm{~min}$ at ambient temperature. The bi-functional reagent BS3 (ThermoPierce, IL, USA) was added at $12.5 \mu \mathrm{M}$ final concentration, and the mixture was incubated for a further $30 \mathrm{~min}$ at ambient temperature. Reactions were stopped by the addition of Tris- $\mathrm{HCl}$ to $50 \mathrm{mM}$ final concentration, and incubated at ambient temperature for a final 15 min. Samples were boiled in SDS-PAGE loading buffer under reducing conditions. IN multimers were visualized by SDS-PAGE and Western blot analysis [63].

\section{Conclusions}

A series of novel 1,5-diaryl-1H-imidazole-4-carboxylic acids 10 and 1,5-diaryl-1Himidazole-4-carbohydrazides $\mathbf{1 1}$ were designed and synthesized via the formation of 1,5-diaryl- $1 H$-imidazole-4-carboxylate ester intermediates $\mathbf{1 7}$ obtained from cycloaddition of ethyl isocyanoacetate $\mathbf{1 6}$ and stable diarylimidoyl chlorides $\mathbf{1 5}$ under basic conditions. This study was conducted to evaluate the hypothesis that the HIV-1 IN activity of the hit compound 9 could be greatly improved through the addition of carboxylic acid and carbohydrazide motifs. This idea was demonstrated to be productive, since seventeen scaffolds (i.e., 10a-d, 10f, 10h-k, 11a-b, 11d-e, 11h-k) exhibited more than 50\% inhibitory activity in disrupting the HIV-1 IN- LEDGF/p75 protein-protein interaction in a direct AlphaScreen ${ }^{\mathrm{TM}}$ assay at $100 \mu \mathrm{M}$. The specific binding of these compounds to the LEDGF/p75-binding pocket was also established by their further assessment in the HIV-1 IN strand transfer assay at $100 \mu \mathrm{M}$, which concluded that none of the compounds (with the exception of 10a, 101, and 11k with marginal inhibitory percentage activities of $44 \%, 39 \%$, and $43 \%$, respectively) were actively bound to the active site. In a cell-based assay, the newly targeted compounds exhibited varying degrees of toxicity, with 13 compounds having a $C_{50}$ value of greater than or equal to $100 \mu \mathrm{M}$, while 9 compounds were found to exhibit $\mathrm{CC}_{50}$ values of below $100 \mu \mathrm{M}$. Further evaluation of the compounds in an antiviral HIV-1 assay revealed four compounds (11a, 11b, 11g, and 11h) with moderate antiviral percentage activities ranging from 33 to $45 \%$ and with $\mathrm{CC}_{50}$ values ranging from $50.4 \mu \mathrm{M}$ to $>200 \mu \mathrm{M}$. The antiviral percentage activity displayed by $\mathbf{1 1 h}$ was credited to its relatively high toxicity of $50.4 \mu \mathrm{M}$. Compounds $\mathbf{1 1 a}, \mathbf{1 1} \mathbf{b}, \mathbf{1 1}$, and $\mathbf{1 1 h}$ were further validated for their ability to 
induce multimerization in a Western blot gel assay, and three compounds, 11a, 11b, and 11h seemed to increase higher-order forms of IN. These data serve as a good starting point for the further optimization of these scaffolds as possible anti-HIV-1 IN drugs. Therefore, efforts are currently underway in our laboratories to improve the potency and enhance the drug-like properties of these compounds.

Supplementary Materials: The following are available online. ${ }^{1} \mathrm{H}$ - and ${ }^{13} \mathrm{C}-\mathrm{NMR}$ spectra (Figures S1-S68) of all novel synthesized molecules.

Author Contributions: Conceptualization, T.J.R., E.M.C. and M.L.B.; methodology, T.J.R. and M.Q.F.; investigation, T.J.R. and M.Q.F.; writing—original draft, T.J.R.; writing—review and editing. E.M.C. and M.L.B.; supervision, E.M.C. and M.L.B. All authors have read and agreed to the published version of the manuscript.

Funding: We acknowledge with thanks the financial support from the National Research Foundation Professional Development Program (UID: 78999) of South Africa, Mintek and the University of the Witwatersrand for support.

Institutional Review Board Statement: Not applicable.

Informed Consent Statement: Not applicable.

Data Availability Statement: Data is contained within the article or Supplementary Material.

Conflicts of Interest: No potential conflict of interest was reported by the authors.

Sample Availability: Samples of the compounds are available on request from the corresponding authors.

\section{References}

1. Adamson, C.S.; Freed, E.O. Anti-HIV-1 Therapeutics: From FDA-approved Drugs to Hypothetical Future Targets. Mol. Interv. 2009, 9, 70-74. [CrossRef] [PubMed]

2. Mega, E.R. Alarming surge in drug-resistant HIV uncovered. Nat. Cell Biol. 2019. [CrossRef] [PubMed]

3. Anstett, K.; Brenner, B.; Mesplede, T.; Wainberg, M.A. HIV drug resistance against strand transfer integrase inhibitors. Retrovirology 2017, 14, 36. [CrossRef] [PubMed]

4. Günthard, H.F.; Calvez, V.; Paredes, R.; Pillay, D.; Shafer, R.W.; Wensing, A.M.; Jacobsen, D.M.; Richman, D.D. Human Immunodeficiency Virus Drug Resistance: 2018 Recommendations of the International Antiviral Society-USA Panel. Clin. Infect. Dis. 2019, 68, 177-187. [CrossRef]

5. Inzaule, S.C.; Ondoa, P.; Peter, T.; Mugyenyi, P.N.; Stevens, W.S.; de Wit, T.F.R.; Hamers, R.L. Affordable HIV drug-resistance testing for monitoring of antiretroviral therapy in sub-Saharan Africa. Lancet Infect. Dis. 2016, 16, e267-e275. [CrossRef]

6. Clavel, F.; Hance, A.J. HIV Drug Resistance. N. Engl. J. Med. 2004, 350, 1023-1035. [CrossRef]

7. Wainberg, M.A.; Zaharatos, G.J.; Brenner, B. Development of Antiretroviral Drug Resistance. N. Engl. J. Med. 2011, 365, 637-646. [CrossRef]

8. Christ, F.; Debyser, Z. The LEDGF/p75 integrase interaction, a novel target for anti-HIV therapy. Virology 2013, 435, 102-109. [CrossRef]

9. Cherepanov, P.; Ambrosio, A.; Rahman, S.; Ellenberger, T.; Engelman, A. Structural basis for the recognition between HIV-1 integrase and transcriptional coactivator p75. Proc. Natl. Acad. Sci. USA 2005, 102, 17308-17313. [CrossRef]

10. Maertens, G.; Cherepanov, P.; Pluymers, W.; Busschots, K.; De Clercq, E.; Debyser, Z.; Engelborghs, Y. LEDGF/p75 Is Essential for Nuclear and Chromosomal Targeting of HIV-1 Integrase in Human Cells. J. Biol. Chem. 2003, 278, 33528-33539. [CrossRef]

11. Esposito, D.; Craigie, R. HIV Integrase Structure and Function. Adv. Appl. Microbiol. 1999, 52, 319-333. [CrossRef]

12. Chen, J.C.-H.; Krucinski, J.; Miercke, L.J.W.; Finer-Moore, J.S.; Tang, A.H.; Leavitt, A.D.; Stroud, R.M. Crystal structure of the HIV-1 integrase catalytic core and C-terminal domains: A model for viral DNA binding. Proc. Natl. Acad. Sci. USA 2000, 97, 8233-8238. [CrossRef]

13. Li, X.; Krishnan, L.; Cherepanov, P.; Engelman, A. Structural biology of retroviral DNA integration. Virology 2011, 411, 194-205. [CrossRef]

14. Engelman, A.; Cherepanov, P. The structural biology of HIV-1: Mechanistic and therapeutic insights. Nat. Rev. Genet. 2012, 10, 279-290. [CrossRef]

15. Schröder, A.R.; Shinn, P.; Chen, H.; Berry, C.; Ecker, J.; Bushman, F. HIV-1 Integration in the Human Genome Favors Active Genes and Local Hotspots. Cell 2002, 110, 521-529. [CrossRef]

16. Summa, V.; Petrocchi, A.; Bonelli, F.; Crescenzi, B.; Donghi, M.; Ferrara, M.; Fiore, F.; Gardelli, C.; Gonzalez Paz, O.; Hazuda, D.J.; et al. Discovery of Raltegravir, a Potent, Selective Orally Bioavailable HIV-Integrase Inhibitor for the Treatment of HIV-AIDS Infection. J. Med. Chem. 2008, 51, 5843-5855. [CrossRef] 
17. Sato, M.; Kawakami, H.; Motomura, T.; Aramaki, H.; Matsuda, T.; Yamashita, M.; Ito, Y.; Matsuzaki, Y.; Yamataka, K.; Ikeda, S.; et al. Quinolone Carboxylic Acids as a Novel Monoketo Acid Class of Human Immunodeficiency Virus Type 1 Integrase Inhibitors. J. Med. Chem. 2009, 52, 4869-4882. [CrossRef]

18. Johns, B.A.; Kawasuji, T.; Weatherhead, J.G.; Taishi, T.; Temelkoff, D.P.; Yoshida, H.; Akiyama, T.; Taoda, Y.; Murai, H.; Kiyama, R.; et al. Carbamoyl Pyridone HIV-1 Integrase Inhibitors 3. A Diastereomeric Approach to Chiral Nonracemic Tricyclic Ring Systems and the Discovery of Dolutegravir (S/GSK1349572) and (S/GSK1265744). J. Med. Chem. 2013, 56, 5901-5916. [CrossRef]

19. Tsiang, M.; Jones, G.S.; Goldsmith, J.; Mulato, A.; Hansen, D.; Kan, E.; Tsai, L.; Bam, R.A.; Stepan, G.; Stray, K.M.; et al. Antiviral Activity of Bictegravir (GS-9883), a Novel Potent HIV-1 Integrase Strand Transfer Inhibitor with an Improved Resistance Profile. Antimicrob. Agents Chemother. 2016, 60, 7086-7097. [CrossRef]

20. Christ, F.; Voet, A.; Marchand, A.; Nicolet, S.; Desimmie, B.; Marchand, D.; Bardiot, D.; Van Der Veken, N.J.; Van Remoortel, B.; Strelkov, S.V.; et al. Rational design of small-molecule inhibitors of the LEDGF/p75-integrase interaction and HIV replication. Nat. Chem. Biol. 2010, 6, 442-448. [CrossRef]

21. Le Rouzic, E.; Bonnard, D.; Chasset, S.; Bruneau, J.-M.; Chevreuil, F.; Le Strat, F.; Nguyen, J.; Beauvoir, R.; Amadori, C.; Brias, J.; et al. Dual inhibition of HIV-1 replication by integrase-LEDGF allosteric inhibitors is predominant at the post-integration stage. Retrovirology 2013, 10, 144. [CrossRef]

22. Christ, F.; Shaw, S.; Demeulemeester, J.; Desimmie, B.A.; Marchand, A.; Butler, S.; Smets, W.; Chaltin, P.; Westby, M.; Debyser, Z.; et al. Small-Molecule Inhibitors of the LEDGF/p75 Binding Site of Integrase Block HIV Replication and Modulate Integrase Multimerization. Antimicrob. Agents Chemother. 2012, 56, 4365-4374. [CrossRef]

23. Desimmie, B.; Schrijvers, R.; Demeulemeester, J.; Borrenberghs, D.; Weydert, C.; Thys, W.; Vets, S.; Van Remoortel, B.; Hofkens, J.; De Rijck, J.; et al. LEDGINs inhibit late stage HIV-1 replication by modulating integrase multimerization in the virions. Retrovirology 2013, 10, 57. [CrossRef]

24. Fader, L.D.; Malenfant, E.; Parisien, M.; Carson, R.; Bilodeau, F.; Landry, S.; Pesant, M.; Brochu, C.; Morin, S.; Chabot, C.; et al. Discovery of BI 224436, a Noncatalytic Site Integrase Inhibitor (NCINI) of HIV-1. ACS Med. Chem. Lett. 2014, 5, $422-427$. [CrossRef]

25. Amadori, C.; Van Der Velden, Y.U.; Bonnard, D.; Orlov, I.; Van Bel, N.; Le Rouzic, E.; Miralles, L.; Brias, J.; Chevreuil, F.; Spehner, D.; et al. The HIV-1 integrase-LEDGF allosteric inhibitor MUT-A: Resistance profile, impairment of virus maturation and infectivity but without influence on RNA packaging or virus immunoreactivity. Retrovirology 2017, 14, 50. [CrossRef]

26. Sharma, A.; Slaughter, A.; Jena, N.; Feng, L.; Kessl, J.J.; Fadel, H.J.; Malani, N.; Male, F.; Wu, L.; Poeschla, E.; et al. A New Class of Multimerization Selective Inhibitors of HIV-1 Integrase. PLOS Pathog. 2014, 10, e1004171. [CrossRef]

27. Fenwick, C.; Amad, M.; Bailey, M.D.; Bethell, R.; Bös, M.; Bonneau, P.; Cordingley, M.; Coulombe, R.; Duan, J.; Edwards, P.; et al. Preclinical Profile of BI 224436, a Novel HIV-1 Non-Catalytic-Site Integrase Inhibitor. Antimicrob. Agents Chemother. 2014, 58, 3233-3244. [CrossRef]

28. Serrao, E.; Xu, Z.-L.; Debnath, B.; Christ, F.; Debyser, Z.; Long, Y.-Q.; Neamati, N. Discovery of a novel 5-carbonyl-1H-imidazole4-carboxamide class of inhibitors of the HIV-1 integrase-LEDGF/p75 interaction. Bioorg. Med. Chem. 2013, 21, 5963-5972. [CrossRef]

29. Sanchez, T.W.; Debnath, B.; Christ, F.; Otake, H.; Debyser, Z.; Neamati, N. Discovery of novel inhibitors of LEDGF/p75-IN protein-protein interactions. Bioorg. Med. Chem. 2013, 21, 957-963. [CrossRef]

30. Rashamuse, T.J.; Harrison, A.T.; Mosebi, S.; van Vuuren, S.; Coyanis, E.M.; Bode, M.L. Design, synthesis and biological evaluation of imidazole and oxazole fragments as HIV-1 integrase-LEDGF/p75 disruptors and inhibitors of microbial pathogens. Bioorg. Med. Chem. 2020, 28, 115210. [CrossRef]

31. Tintori, C.; Demeulemeester, J.; Franchi, L.; Massa, S.; Debyser, Z.; Christ, F.; Botta, M. Discovery of small molecule HIV-1 integrase dimerization inhibitors. Bioorg. Med. Chem. Lett. 2012, 22, 3109-3114. [CrossRef] [PubMed]

32. Dolšak, A.; Švajger, U.; Lešnik, S.; Konc, J.; Gobec, S.; Sova, M. Selective Toll-like receptor 7 agonists with novel chromeno[3,4d]imidazol-4(1H)-one and 2-(trifluoromethyl)quinoline/ quinazoline-4-amine scaffolds. Eur. J. Med. Chem. 2019, 179, 109-122. [CrossRef] [PubMed]

33. Meng, T.; Zou, Y.; Khorev, O.; Jin, Y.; Zhou, H.; Zhang, Y.; Hu, D.; Ma, L.; Wang, X.; Shen, J. Synthesis of 3-Aminocoumarin and Derivatives via Copper Catalysis. Synfacts 2011, 2011, 0717. [CrossRef]

34. Gulevich, A.V.; Zhdanko, A.G.; Orru, R.V.A.; Nenajdenko, V.G. Isocyanoacetate Derivatives: Synthesis, Reactivity, and Application. Chem. Rev. 2010, 110, 5235-5331. [CrossRef] [PubMed]

35. Bode, M.L.; Gravestock, D.; Rousseau, A.L. Synthesis, Reactions and Uses of Isocyanides in Organic Synthesis. An Update. Org. Prep. Proced. Int. 2016, 48, 89-221. [CrossRef]

36. Suzuki, M.; Moriya, T.; Matsumoto, K.; Miyoshi, M. A New Convenient Synthesis of 5-Amino-1,3-thiazole-4-carboxylic Acids. Synthesis 1982, 1982, 874-875. [CrossRef]

37. Baxendale, I.; Ley, S.; Smith, C.; Tamborini, L.; Voica, A.-F. A Bifurcated Pathway to Thiazoles and Imidazoles Using a Modular Flow Microreactor. J. Comb. Chem. 2008, 10, 851-857. [CrossRef] [PubMed]

38. Hunt, J.T.; Bartlett, P.A. Regioselective Synthesis of 5-Amino-4-imidazolecarboxylates via Isonitrile Cycloaddition. Synthesis 1978, 1978, 741-742. [CrossRef]

39. Nunami, K.-I.; Yamada, M.; Fukui, T.; Matsumoto, K. A Novel Synthesis of Methyl 1,5-Disubstituted Imidazole-4-carboxylates Using 3-Bromo-2-isocyanoacrylates (BICA). J. Org. Chem. 1994, 59, 7635-7642. [CrossRef] 
40. Aguilar, A.; Zhou, H.; Chen, J.; Liu, L.; Bai, L.; McEachern, D.; Yang, C.-Y.; Meagher, J.; Stuckey, J.; Wang, S. A Potent and Highly Efficacious Bcl-2/Bcl-xL Inhibitor. J. Med. Chem. 2013, 56, 3048-3067. [CrossRef]

41. Cai, J.; Bai, H.; Wang, Y.; Xu, X.; Xie, H.; Liu, J. Base-mediated regioselective [3+2] annulation of ketenimines and isocyanides: Efficient synthesis of 1,4,5-trisubstituted imidazoles. Chem. Commun. 2019, 55, 3821-3824. [CrossRef]

42. Hu, S.; Yang, H.; Chen, Z.; Wu, X.-F. Base-mediated [3+2] annulation of trifluoroacetimidoyl chlorides and isocyanides: An improved approach for regioselective synthesis of 5-trifluoromethyl-imidazoles. Tetrahedron 2020, 76, 131168. [CrossRef]

43. Lv, L.; Chen, Y.; Shatskiy, A.; Liu, J.; Liu, X.; Kärkäs, M.D.; Wang, X. Silver-Catalyzed [3+1+1] Annulation of Nitrones with Isocyanoacetates as an Approach to 1,4,5-Trisubstituted Imidazoles. Eur. J. Org. Chem. 2021, 2021, 964-968. [CrossRef]

44. Schlosser, J.; Johannes, E.; Zindler, M.; Lemmerhirt, J.; Sommer, B.; Schütt, M.; Peifer, C. Novel synthesis of benzofuran- and indol-2-yl-methanamine derivatives. Tetrahedron Lett. 2015, 56, 89-94. [CrossRef]

45. Deng, H.; Fang, Y. Synthesis and Agonistic Activity at the GPR35 of 5,6-Dihydroxyindole-2-carboxylic Acid Analogues. ACS Med. Chem. Lett. 2012, 3, 550-554. [CrossRef]

46. Zhang, E.; Guo, H.; Chen, D.; Yang, Q.; Fan, Y.; Yin, Y.; Wang, W.; Chen, D.; Wang, S.; Liu, W. Mutational biosynthesis to generate novel analogs of nosiheptide featuring a fluorinated indolic acid moiety. Org. Biomol. Chem. 2020, 18, 4051-4055. [CrossRef]

47. Ren, Z.-L.; Guan, Z.-R.; Kong, H.-H.; Ding, M.-W. Multifunctional odorless isocyano(triphenylphosphoranylidene)-acetates: Synthesis and direct one-pot four-component Ugi/Wittig cyclization to multisubstituted oxazoles. Org. Chem. Front. 2017, 4, 2044-2048. [CrossRef]

48. Bongards, C.; Gärtner, W. The Role of the Chromophore in the Biological Photoreceptor Phytochrome: An Approach Using Chemically Synthesized Tetrapyrroles. Accounts Chem. Res. 2010, 43, 485-495. [CrossRef]

49. Latham, A.N.; Ferrence, G.M.; Lash, T.D. Metalation and Methyl Group Migration in 21-, 22-, and 23-Methylcarbaporphyrins: Synthesis and Characterization of Palladium(II), Rhodium(I), and Rhodium(III) Derivatives. Organometallics 2019, 38, 575-585. [CrossRef]

50. Garrido, M.; Corredor, M.; Orzáez, M.; Alfonso, I.; Messeguer, A. Regioselective Synthesis of a Family of $\beta$-Lactams Bearing a Triazole Moiety as Potential Apoptosis Inhibitors. ChemistryOpen 2016, 5, 485-494. [CrossRef]

51. Genin, M.J.; Allwine, D.A.; Anderson, D.J.; Barbachyn, M.R.; Emmert, D.E.; Garmon, S.A.; Graber, D.R.; Grega, K.C.; Hester, J.B.; Hutchinson, D.K.; et al. Substituent Effects on the Antibacterial Activity of Nitrogen-Carbon-Linked (Azolylphenyl)oxazolidinones with Expanded Activity Against the Fastidious Gram-Negative OrganismsHaemophilusinfluenzaeandMoraxellacatarrhalis. J. Med. Chem. 2000, 43, 953-970. [CrossRef]

52. Lai, Y.-Y.; Huang, L.-J.; Lee, K.-H.; Xiao, Z.; Bastow, K.F.; Yamori, T.; Kuo, S.-C. Synthesis and biological relationships of 3',6substituted 2-phenyl-4-quinolone-3-carboxylic acid derivatives as antimitotic agents. Bioorg. Med. Chem. 2005, 13, 265-275. [CrossRef]

53. Caiuby, C.A.D.; de Jesus, M.P.; Burtoloso, A.C.B. $\alpha$-Imino Iridium Carbenes from Imidoyl Sulfoxonium Ylides: Application in the One-Step Synthesis of Indoles. J. Org. Chem. 2020, 85, 7433-7445. [CrossRef]

54. Liu, G.; Wu, X.; Shi, X. Synthesis of Polysubstituted-1,2,4-Triazoles. J. Heterocycl. Chem. 2013, 50, 39. [CrossRef]

55. You, X.; Xie, X.; Sun, R.; Chen, H.; Li, S.; Liu, Y. Titanium-mediated cross-coupling reactions of 1,3-butadiynes with $\alpha$-iminonitriles to 3-aminopyrroles: Observation of an imino aza-Nazarov cyclization. Org. Chem. Front. 2014, 1, 940-946. [CrossRef]

56. Liu, X.; Wu, P.; Li, J.; Cui, C. Synthesis of 1,2-Borazaronaphthalenes from Imines by Base-Promoted Borylation of C-H bond. J. Org. Chem. 2015, 80, 3737-3744. [CrossRef]

57. Zhou, H.; Aguilar, A.; Chen, J.; Bai, L.; Liu, L.; Meagher, J.L.; Yang, C.-Y.; McEachern, D.; Cong, X.; Stuckey, J.A.; et al. StructureBased Design of Potent Bcl-2/Bcl-xL Inhibitors with Strong in Vivo Antitumor Activity. J. Med. Chem. 2012, 55, $6149-6161$. [CrossRef]

58. Peat, T.S.; Rhodes, D.I.; Vandegraaff, N.; Le, G.; Smith, J.A.; Clark, L.J.; Jones, E.D.; Coates, J.A.V.; Thienthong, N.; Newman, J.; et al. Small Molecule Inhibitors of the LEDGF Site of Human Immunodeficiency Virus Integrase Identified by Fragment Screening and Structure Based Design. PLoS ONE 2012, 7, e40147. [CrossRef] [PubMed]

59. Abrahams, S.; Mosebi, S.; Fish, M.Q.; Papathanasopoulos, M.A.; Hewer, R. Screening of the NIH Clinical Collection for inhibitors of HIV-1 integrase activity. S. Afr. J. Sci. 2018, 114, 1-5. [CrossRef]

60. Harada, S.; Koyanagi, Y.; Yamamoto, N. Infection of HTLV-III/LAV in HTLV-I-carrying cells MT-2 and MT-4 and application in a plaque assay. Science 1985, 229, 563-566. [CrossRef] [PubMed]

61. Harbut, M.B.; Vilchèze, C.; Luo, X.; Hensler, M.E.; Guo, H.; Yang, B.; Chatterjee, A.K.; Nizet, V.; Jacobs, W.; Schultz, P.G.; et al. Auranofin exerts broad-spectrum bactericidal activities by targeting thiol-redox homeostasis. Proc. Natl. Acad. Sci. USA 2015, 112, 4453-4458. [CrossRef]

62. van Meerloo, J.; Kaspers, G.J.L.; Cloos, J. Cell Sensitivity Assays: The MTT Assay; Humana Press: Totowa, NJ, USA, 2011; Volume 731, pp. 237-245. [CrossRef]

63. Li, M.; Mizuuchi, M.; Burke, T.R.; Craigie, R. Retroviral DNA integration: Reaction pathway and critical intermediates. EMBO J. 2006, 25, 1295-1304. [CrossRef]

64. Jurado, K.A.; Wang, H.; Slaughter, A.; Feng, L.; Kessl, J.J.; Koh, Y.; Wang, W.; Ballandras-Colas, A.; Patel, P.A.; Fuchs, J.R.; et al. Allosteric integrase inhibitor potency is determined through the inhibition of HIV-1 particle maturation. Proc. Natl. Acad. Sci. USA 2013, 110, 8690-8695. [CrossRef] 
65. Kessl, J.J.; Jena, N.; Koh, Y.; Taskent-Sezgin, H.; Slaughter, A.; Feng, L.; de Silva, S.; Wu, L.; Le Grice, S.F.J.; Engelman, A.; et al. Multimode, Cooperative Mechanism of Action of Allosteric HIV-1 Integrase Inhibitors. J. Biol. Chem. 2012, 287, 16801-16811. [CrossRef]

66. Madhavi Sastry, G.; Adzhigirey, M.; Day, T.; Annabhimoju, R.; Sherman, W. Protein and ligand preparation: Parameters, protocols, and influence on virtual screening enrichments. J. Comput. Mol. Des. 2013, 27, 221-234. [CrossRef]

67. Halgren, T.A.; Murphy, R.B.; Friesner, R.A.; Beard, H.S.; Frye, L.L.; Pollard, W.T.; Banks, J.L. Glide: A New Approach for Rapid, Accurate Docking and Scoring. 2. Enrichment Factors in Database Screening. J. Med. Chem. 2004, 47, 1750-1759. [CrossRef]

68. Friesner, R.A.; Banks, J.L.; Murphy, R.B.; Halgren, T.A.; Klicic, J.J.; Mainz, D.T.; Repasky, M.P.; Knoll, E.H.; Shelley, M.; Perry, J.K.; et al. Glide: A New Approach for Rapid, Accurate Docking and Scoring. 1. Method and Assessment of Docking Accuracy. J. Med. Chem. 2004, 47, 1739-1749. [CrossRef]

69. Rosenwirth, B.; Billich, A.; Datema, R.; Donatsch, P.; Hammerschmid, F.; Harrison, R.; Hiestand, P.; Jaksche, H.; Mayer, P.; Peichl, P. Inhibition of human immunodeficiency virus type 1 replication by SDZ NIM 811, a nonimmunosuppressive cyclosporine analog. Antimicrob. Agents Chemother. 1994, 38, 1763-1772. [CrossRef] 